Aus der Poliklinik für Präventive Zahnmedizin, Parodontologie und Kariologie

(Prof. Dr. A. Wiegand)

im Zentrum Zahn-, Mund- und Kieferheilkunde

der Medizinischen Fakultät der Universität Göttingen

\title{
Etablierung eines 3D-Tissue-Engineering-Modells zur Bindegewebsherstellung
}

\author{
INAUGURAL-DISSERTATION \\ zur Erlangung des Doktorgrades \\ für Zahnheilkunde \\ der Medizinischen Fakultät der \\ Georg-August-Universität zu Göttingen
}

vorgelegt von

Hevin Karatas

aus

Cilesiz

Göttingen 2015 
Dekan:

I. Berichterstatter: $\quad$ PD Dr. med. dent. Dirk Ziebolz, M.Sc.

II. Berichterstatter/in: Prof. Dr. med. Nicolai Miosge

III. Berichterstatter/in: Prof. Dr. med. dent. Rainer Mausberg

Tag der mündlichen Prüfung: 21.09.2015 


\section{Abkürzungsverzeichnis:}

$\begin{array}{ll}\% & \text { Prozent } \\ \% \text { ig } & \text { prozentig } \\ { }^{\circ} \mathrm{C} & \text { Grad Celsius } \\ \mu \mathrm{l} & \text { Mikroliter } \\ \mu \mathrm{m} & \text { Mikrometer } \\ \text { 2D } & \text { zweidimensional } \\ \text { 3D } & \text { dreidimensional }\end{array}$

Abb. Abbildung

AP alkalische Phosphatase

BSA bovines Serum-Albumin

BSE bovine spongiforme Enzephalopathie

ca. circa

$\mathrm{cm} \quad$ Zentimeter

$\mathrm{cm}^{2} \quad$ Quadratzentimeter

DMEM Dulbecco's Modified Eagle Medium

DNA Desoxyribonukleinsäure

EDTA Ethylendiamintetraacetat

et al. et alii/et aliae

EZM Extrazellulärmatrix

FKS fetales Kälber-Serum

g Gramm

ggf. gegebenenfalls

H. E. Hämatoxylin-Eosin

$\mathrm{HCl}$ Chlorwasserstoff (Salzsäure)

$1 \quad$ Liter

M Molarität

MDCK Madin-Darby-Canine-Kidney-Zellen

mg Milligram

$\mathrm{MgCl}_{2} \quad$ Magnesiumchlorid

Min. Minute/-n

Mio. Million/-en

$\mathrm{ml} \quad$ Milliliter

$\mathrm{mm} \quad$ Millimeter

$\mathrm{mM} \quad$ Millimolar

mMol Millimol

$\mathrm{N} \quad$ Normalität

$\mathrm{NaOH} \quad$ Natriumhydroxid 


$\begin{array}{ll}\text { nm } & \text { Nanometer } \\ \text {-OH } & \text { Hydroxid } \\ \text { PBS } & \text { phosphate buffered saline } \\ \text { Pen/Strep } & \text { Penicillin/Streptomycin } \\ \text { PHEMA } & \text { Polyhydroxyethylmethacrylat } \\ \text { PMMA } & \text { Polymethylmethacrylat } \\ \text { rhBMP-2 } & \text { recombinant human bone morphogenetic protein-2 } \\ \text { S. } & \text { Seite } \\ \text { s. } & \text { siehe } \\ \text { T. E. } & \text { tissue engineering } \\ \text { Tab. } & \text { Tabelle } \\ \text { TdT } & \text { terminale Desoxynukleotid-Transferase } \\ \text { TUNEL } & \text { TdT-mediated dUTP nick end labeling } \\ \text { U/ml } & \text { Units/Milliliter } \\ \text { UpM } & \text { Umdrehungen pro Minute } \\ \text { UV } & \text { ultraviolett } \\ \text { v.a. } & \text { vor allem } \\ \text { vgl. } & \text { vergleiche } \\ \text { Vol. \% } & \text { Volumenprozent } \\ & \end{array}$




\section{Inhaltsverzeichnis}

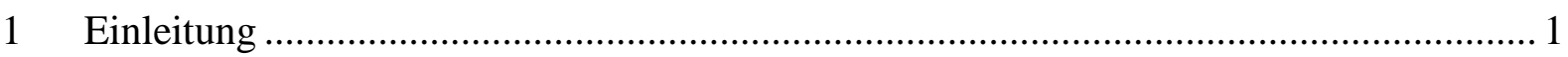

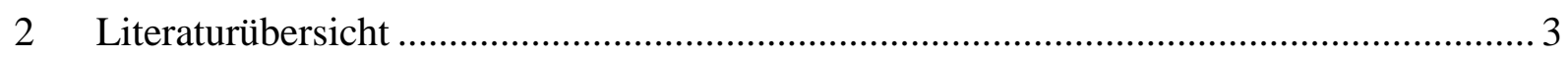

2.1 Die Schleimhaut der Mundhöhle ....................................................................... 3

2.2 Orale Weichgewebsverluste .......................................................................... 4

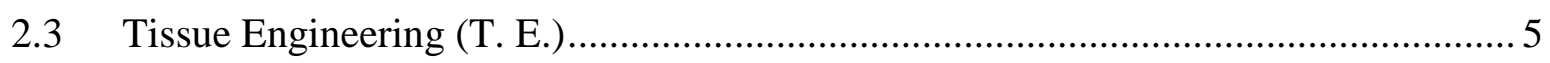

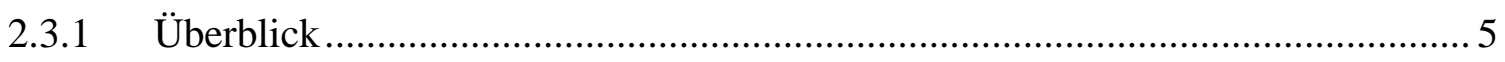

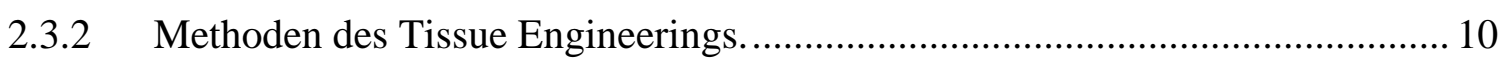

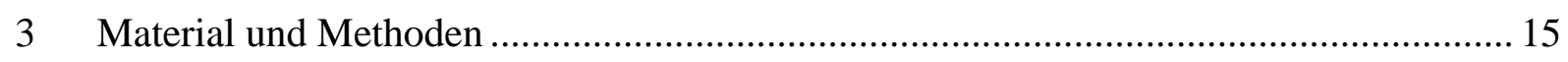

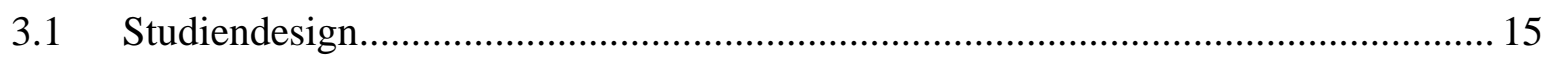

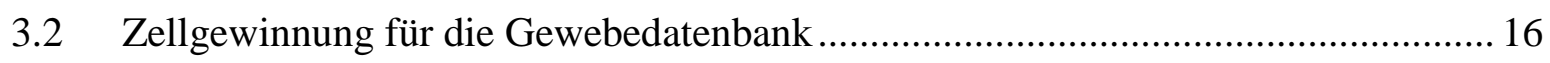

$3.3 \quad$ 2D-Zellkultur mit Expansion der Zellzahl...................................................... 17

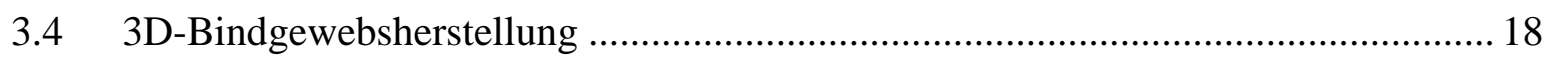

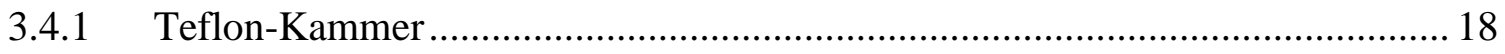

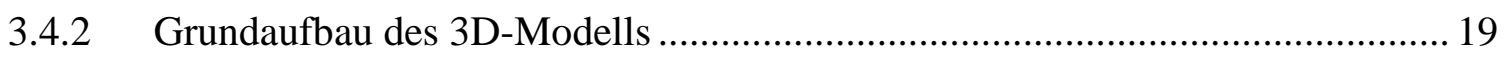

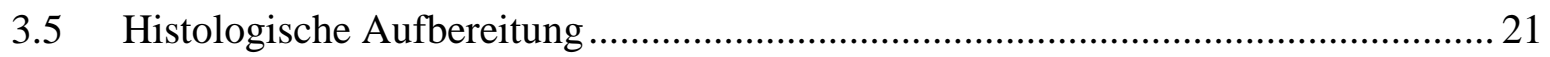

3.5.1 Vorbereitung für die Histologie ........................................................... 21

3.5.2 Ermittlung der Gewebedicke und Homogenität............................................. 23

3.5.3 Bestimmung der Apoptose-Rate …........................................................... 27

3.5.4 Untersuchung des Kollagen-Netzwerks ................................................... 30

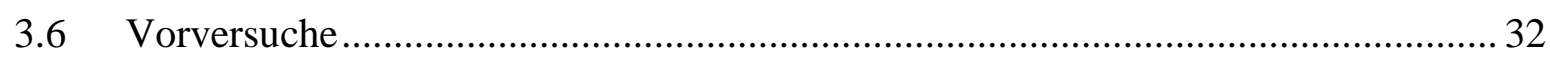

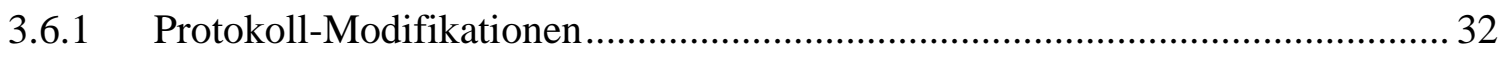

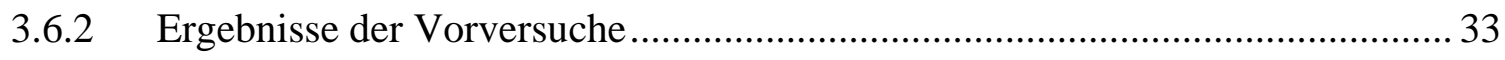

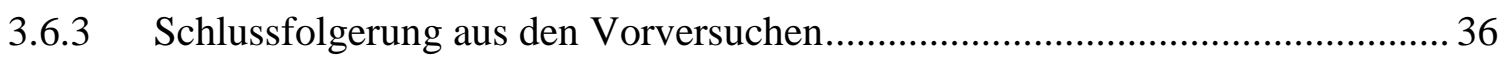

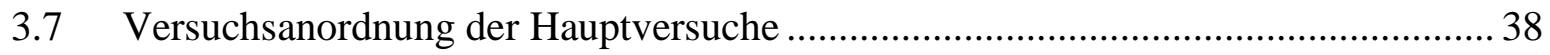

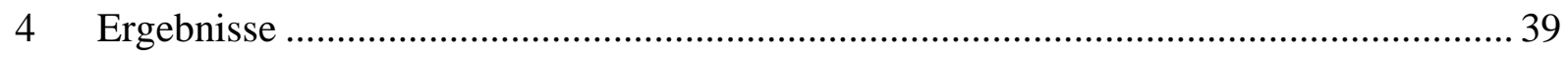

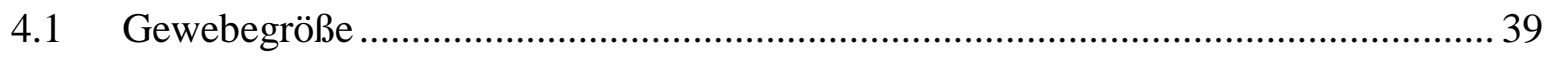

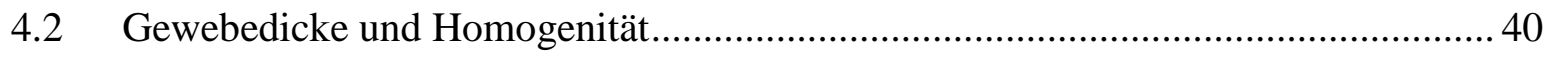




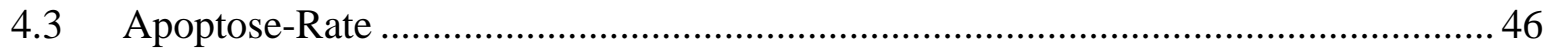

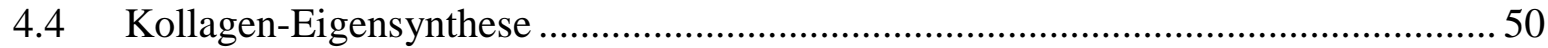

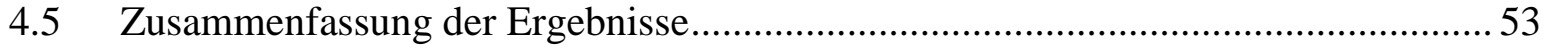

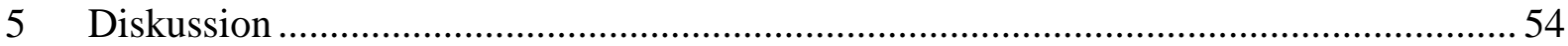

5.1 Diskussion des Versuchsaufbaus und der Methode ...............................................54

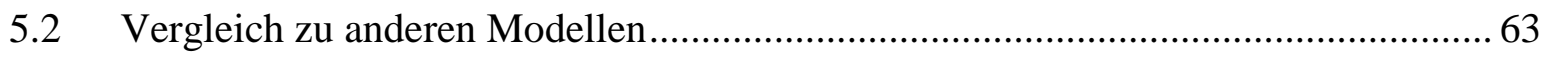

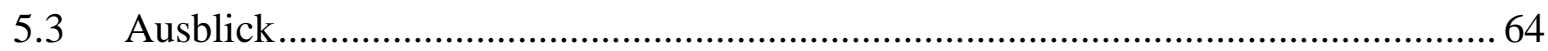

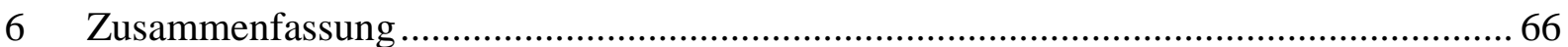

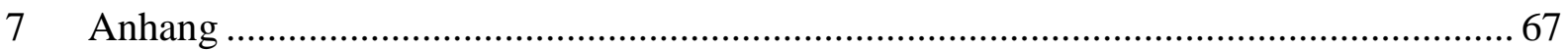

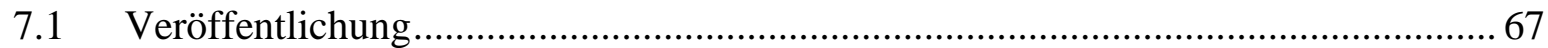

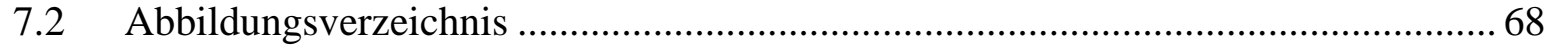

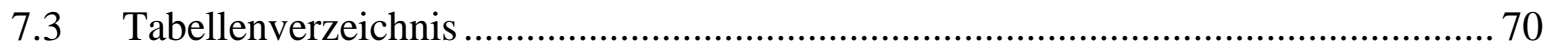

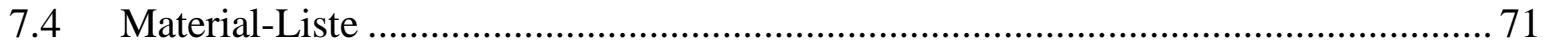

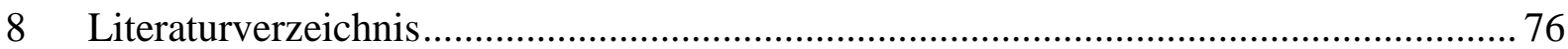




\section{Einleitung}

Orale Weichgewebsverluste schränken Patienten ein und stellen Ärzte und Zahnärzte vor eine Herausforderung. Die aktuelle Medizin und Forschung bieten zahlreiche Lösungen an, um Weichgewebsverluste zu versorgen. Neben den bewährten Transplantaten zur Defektdeckung eröffnen sich mit dem Gebiet des Tissue Engineerings neue Optionen. Im Labor gezüchtete dreidimensionale Gewebe-Rekonstruktionen mit Potenzial zur Implantation können zukünftig das Ausmaß des bisher Möglichen erweitern.

Diverse Arbeitsgruppen setzen sich bereits mit der Entwicklung von Konzepten zur Gewebeherstellung im Verfahren des 3D-Tissue-Engineerings auseinander. Sie beschäftigen sich dabei unter anderem mit der Rekonstruktion von:

- Muskulatur (Bach et al. 2003)

- Knochen (Zou et al. 2013)

- $\quad$ Knorpel (Gong et al. 2007; Lee et al. 2013)

- $\quad$ Haut (Chen et al. 2009)

- Blutgefäßen (L'Heureux et al. 2006; Neff et al. 2011; Quint et al. 2012).

Auch die Induktion einer Nervenregeneration nach einem Trauma (Battiston et al. 2009; Raimondo et al. 2011) oder die Bekämpfung des Diabetes mellitus mittels Pankreas-Modellen (Tziampazis und Sambanis 1995) machen Fortschritte.

In der Zahnmedizin beschäftigen sich Parodontal-Chirurgen mit der Deckung von kleinen Weichgewebsdefekten zur Wiederherstellung von Funktion und Ästhetik des Parodonts. Kleine orale Weichgewebsdefekte wie gingivale Rezessionen können erfolgreich mit subepithelialen Bindegewebstransplanteten in Kombination mit einem koronalen Verschiebelappen (Cairo et al. 2012) oder der sogenannten Tunneltechnik (Rebele et al. 2014) gedeckt werden. Das Spendergewebe wird bei diesen Verfahren hauptsächlich aus dem Gaumen entnommen. Diese Therapieform wird von Parodontalchirurgen bereits mit Erfolg umgesetzt. Einhergehend mit einer solchen Behandlung ist allerdings die Co-Morbidität des Spendergebiets. Ein ZweitOperationsgebiet birgt zudem alle bekannten Risiken und Beeinträchtigungen eines oralchirurgischen Eingriffs (Gellrich et al. 2001). Um diesen Nachteil einer ansonsten klinisch erfolgreichen Methode zur Rezessionsdeckung zu umgehen, ist nach einer alternativen Gewebequelle zu suchen. Einige Arbeitsgruppen beschäftigten sich bereits mit der In-VitroHerstellung von bindegewebeähnlichem Material. Allerdings sind bislang nur wenige Ansätze 
zur Rekonstruktion von oralem Bindegewebe bekannt, welche primäre autologe Zellen verwenden und mit einfachen labortechnischen Mitteln umzusetzen sind.

Deshalb ist das Ziel dieser Arbeit die Etablierung einer standardisierten und einfach umzusetzenden Methode zur Bindegewebsherstellung im Rahmen eines Tissue-Engineering-Modells. Der Erfolg soll im Folgenden anhand der Größe, Dicke, Vitalität und Kollagen-Eigensynthese des hergestellten Gewebe-Konstrukts untersucht werden.

Die Gewebedicke sollte so gewählt sein, dass das Konstrukt noch durch Diffusion nutritiv versorgt werden kann. Als erstrebenswerte Zielgrößen für die Bindegewebskondensate gelten Abmessungen von ca. $1 \mathrm{~cm}^{2}$ und eine Dicke von ca. $1 \mathrm{~mm}$. 


\section{Literaturübersicht}

\subsection{Die Schleimhaut der Mundhöhle}

Die Mundhöhle ist gegliedert in den Mundvorhof (Vestibulum) und die eigentliche Mundhöhle (Cavitas oris propria), welche durch die Zahnreihen unterteilt werden. Begrenzt wird der Mundraum:

- nach vestibulär durch die Lippen,

- nach lateral durch die Wangen,

- nach kranial durch den harten und weichen Gaumen,

- nach kaudal durch den Mundboden und

- nach dorsal durch die Tonsillen.

Als prominente Bestandteile ragen hier die Zähne und die Zunge hinein (Welsch 2006).

Die gesamte Mundhöhle wird von einer Schleimhaut ausgekleidet. Sie besteht aus teils verhorntem, teils unverhorntem mehrschichtigem Plattenepithel mit einer darunter liegenden bindegewebigen Lamina propria. Mancherorts findet sich zudem eine Submukosa mit eingelagerten kleinen Speicheldrüsen. Das Epithel enthält neben Keratinozyten auch Melanozyten, Langerhanszellen und Merkelzellen. Die Lamina propria mit ihrem lockeren kollagenen Bindegewebe enthält Meissner-Tastkörperchen, Abwehrzellen und Fibroblasten, die in einer Extrazellulärmatrix (EZM) eingelagert sind. Die EMZ wird von den Fibroblasten sezerniert und enthält Kollagenfibrillen (vor allem Typ I und III) und elastische Fasern, Glykosaminoglykane (Hyaluronan) und Proteoglykane (v. a. Decorin) sowie Adhäsionsproteine (LüllmannRauch 2007).

Aufgrund struktureller und funktioneller Merkmale kann die Schleimhaut in drei Typen unterteilt werden: die mastikatorische, die auskleidende und die spezialisierte Form. Areale, die beim Kauen mechanisch beansprucht werden, wie Zahnfleisch und harter Gaumen, gehören zur mastikatorischen Schleimhaut. Sie ist gekennzeichnet durch ein verhorntes Epithel (paraund orthokeratinisiert), hohe, dicht stehende Bindegewebspapillen und ist unverschieblich mit ihrer Unterlage verbunden. Lippen, Wangen, Vestibulum, weicher Gaumen, Mundboden und Zungenunterseite sind von der auskleidenden Mukosa bedeckt, welche unverhornt ist und zumeist eine Submukosa mit eingelagerten kleinen Speicheldrüsen aufweist. Die spezialisierte Schleimhaut hingegen findet sich auf dem Zungenrücken und enthält gustatorische, sensible und sensorische Rezeptoren (Welsch 2006; Lüllmann-Rauch 2007). 


\subsection{Orale Weichgewebsverluste}

Unterschiedlichste Faktoren können einen oralen Weichgewebsverlust bedingen. Sie manifestieren sich entweder prä- oder postnatal und können angeboren oder erworben sein. Angeborene syndromale Defekte wie Gesichtsspalten können Grund für ein Fehlen von Muskulatur, Bindegewebe und auch Knochen sein (Kumar und Thapliyal 2012; Wu et al. 2013). Ein postnataler Verlust von weichem oralem Gewebe wird hingegen oftmals iatrogen hervorgerufen und hat zahlreiche Ursachen. Gewebezerstörende Infektionen wie Lepra (Dhillon et al. 2013), Operationen im Mund-, Kiefer, und Gesichtsbereich wie Tumor-Resektionen (Rieck et al. 2013) und diverse Traumata (Holt 1990; Shuker 2010) führen oftmals zu Verlust von oralem Weichgewebe. Kleine orale Weichgewebsdefekte sind oft bedingt durch Entzündungen (Gingivitis und Parodontitis), Fehlbelastungen, Traumata (mechanisch, chemisch, physikalisch, thermisch) und nach oralen operativen Eingriffen (Implantat-Insertion) (Kassab und Cohen 2003; Marini et al. 2004; Allen et al. 2007). Dazu zählen insbesondere gingivale Rezessionen. Bei $88 \%$ der Menschen über 65 Jahren und $50 \%$ der Menschen zwischen 18 und 64 Jahren sind an mindestens einem Zahn Rezessionen zu erkennen (Kassab und Cohen 2003).

Um diese Weichgewebsverluste zu therapieren, gibt es abhängig von der Defektgröße diverse Möglichkeiten. Auf große Gewebsverluste und ihre Therapie mit freien vaskularisierten Lappen soll an dieser Stelle nicht näher eingegangen werden (Riedel und Hörmann 2005; Hurvitz et al. 2006; Thorwarth et al. 2008). Der Fokus soll auf die Deckung kleiner oraler Weichgewebsdefekte aus dem parodontalen Segment gelegt werden. Dazu gehören unter anderem die Rezessionsdeckung, die Weichgewebs-Kammaugmentation, die Papillen-Rekonstruktionen sowie die Implantatlager-Gestaltung. Oberflächliche Weichgewebsverluste können der Selbstheilung überlassen werden oder zum Zwecke einer schnelleren Genesung und Ästhetik mit Kollagen-Matrizes gedeckt werden (Thoma et al. 2012). Zur Versorgung oben genannter parodontaler Defekte können epithelialisierte Transplante wie autologe Schwenklappen, gestielte Lappen und freie Schleimhauttransplantate direkt aus dem Mundraum verwendet werden (Jahnke et al. 1993; Müller et al. 1998; Pilloni et al. 2013). Neben diesen epithelialisierten Transplantaten wird heutzutage jedoch hauptsächlich subepitheliales Bindegewebe aus dem Gaumen z. B. zur Deckung von Rezessionen verwendet (Jahnke et al. 1993, Zuhr et al. 2014). Diese Bindegewebstransplantate in Kombination mit koronalen Verschiebelappen oder Tunnel-Präparationen zeigen dabei gegenüber einem koronalen Verschiebelappen ohne Bindegewebssubstitution klinische Überlegenheit (Cairo et al. 2012, Rebele et al. 2014).

Diese Methoden bringen allerdings Einschränkungen mit sich, wie die Co-Morbidität des Spendergebiets (Gellrich et al. 2001); aber auch ästhetische Einbußen aufgrund einer unein- 
heitlichen Farbe müssen in Kauf genommen werden (Wei et al. 2003). Deshalb stellt die InVitro-Herstellung von Bindegewebe im Verfahren des Tissue Engineering ein attraktives Forschungsgebiet dar. Erste Arbeitsgruppen, die auf dem Fachgebiet des Tissue Engineerings aktiv sind, setzten in dieser Technik bereits mit Erfolg in vitro gezüchtete Gewebe in vivo ein (Thoma et al. 2011; Lotfi et al. 2011).

\subsection{Tissue Engineering (T. E.)}

\subsection{1 Überblick}

Die zweidimensionale Zellkultur wird schon lange mit einfachen Mitteln erfolgreich umgesetzt. Sie rekonstruiert allerdings nicht die tatsächliche Physiologie und Anatomie des zu reproduzierenden Gewebes. Vor größeren Schwierigkeiten sehen sich Forscher bei der Entwicklung eines Konzeptes zur dreidimensionalen Gewebeherstellung. Aspekte wie mechanische und biochemische Limitationen, das Zell-Matrix-Zusammenspiel und Zell-ZellInteraktionen müssen in einem 3D-Modell berücksichtigt werden (Griffith et al. 2005; Justice et al. 2009; Haycock 2011).

Eine allgemein anerkannte Definition für das Tissue Engineering stellten LANGER UND VACANTI 1993 auf. Sie beschrieben es als ein interdisziplinäres Feld, welches die Prinzipien des Ingenieurwesens und der Lebenswissenschaften mit denen der Entwicklung von biologischem Ersatzmaterial vereinigt, mit dem Ziel der Wiederherstellung, Erhaltung oder Verbesserung der Gewebefunktion oder eines ganzen Organs (Langer und Vacanti 1993).

CARLETTI et al. beschrieben das Tissue Engineering 2011 als einen Prozess, der unterschiedliche Materialien, Zellen, Wachstumsfaktoren und/oder bioaktive Moleküle miteinander vereinigt und implantierbare Transplantate hervorbringt, welche Reparaturvorgänge initiieren und die Regeneration von Gewebe an der Implantationsstelle mit untergehendem Gewebe induzieren (Carletti et al. 2011).

Vor der Entwicklung einer Strategie zur dreidimensionalen Bindegewebsherstellung im Verfahren des Tissue Engineerings sind die entsprechenden Einzel-Komponenten hierfür zu wählen. Dazu gehören die Auswahl von:

1. Zelltyp

2. Zellkulturmedium

3. mechanischem Grundgerüst

4. 3D-Kulturkammer. 


\section{Zelltypen:}

Die für das T. E. verwendeten Zellen können autologen Ursprungs sein, also vom gleichen Individuum, welchem sie wieder als Gewebe reimplantiert werden. Die autologen Zellen sind für gewöhnlich Primärzellen, wurden also direkt aus dem Organismus entnommen. Sie sind zu unterteilen in mesenchymale Stammzellen oder ausdifferenzierte Zellen aus dem Primärgewebe. Mesenchymale Stammzellen (v. a. aus dem Knochenmark und Fettgewebe) besitzen das Potenzial sich - sowohl in vivo als auch ex vivo - auf Schlüsselreize hin in viele Gewebearten zu differenzieren. Sie weisen zudem eine immunsupprimierende Komponente auf (Ringe et al. 2002; Thesleff und Tummers 2003; Caplan 2007; Rimondini und Mele 2009; Yi und Song 2012; De Miguel et al. 2012).

Sekundäre Zelllinien wie allogene (von anderen Individuen) und xenogene (von einer anderen Spezies) Zellen stammen hingegen aus Zellbanken. Syngene Zellen werden von einem genetisch identischen Individuum (eineiiger Zwilling) gespendet. Es sei zudem der ethisch umstrittene Einsatz von embryonalen (und adulten) Stammzellen (ESZ) zu erwähnen. Der Einsatz vieler dieser genannten Zellen kann mit immunologischen Abstoßungsreaktionen verbunden sein (Thomson et al. 1998; Swijnenburg et al. 2008; Preynat-Seauve et al. 2009).

\section{Zellkulturmedium:}

Das Zellkulturmedium muss entsprechend dem Zelltyp ausgewählt werden. Die prominenten Zellen des oralen Weichgewebes, die Fibroblasten und Epithelzellen, bedürfen jeweils unterschiedlicher Zellkulturmedien. Neben den üblichen Antibiotika und Fungiziden werden diverse weitere Zusätze dem Medium beigemengt. Als Grundlage für beide Nährmedien wird das Standard-Zellkulturmedium DMEM (Dulbecco’s Modified Eagle Medium) verwendet. Wird die Induktion einer Kollagen-Eigensynthese erstrebt, kann zu dem Medium Ascorbinsäure (Vitamin C) hinzugefügt werden. Sie unterstützt als Cofaktor die Ascorbinsäure-abhängige Kollagen-Synthese der entsprechenden Zellen (Pinnell 1985; Tsutsumi et al. 2012).

\section{Mechanisches Grundgerüst:}

Zellen müssen für die dreidimensionale Gewebekultur in ein Grundgerüst eingebettet sein. Das Zusammenspiel zwischen den Zellen und dem Gerüst wird kontrolliert durch Materialeigenschaften und Gerüstcharakteristika. Zu den Aufgaben eines solchen Gerüsts gehören unter anderem die Anregung der Adhäsion, Proliferation und Aktivierung der Zellen. Dazu muss es 
biokompatibel sein und eine entsprechende Porenverteilung und-größe aufweisen (Byrne et al. 2008; Kasten et al. 2008; Carletti et al. 2011).

Die Materialen für Gerüste in der 3D-Zellkultur können unterschieden werden in synthetische und natürliche Polymere.

$\mathrm{Zu}$ den synthetischen Molekülen gehören beispielsweise das biodegradierbare Polylactid (Kim et al. 1998), Polydioxanon (Novotny et al. 2012), Polymethylmethacrylat (PMMA) (Tao et al. 2007) oder Nylon (Polyamid) (Liu et al. 2013).

Natürliche Polymere können aus Pflanzen sowie tierischem und menschlichem Gewebe gewonnen werden. Sie zeichnen sich durch eine gute Biokompatibilität und recht niedrige Toxizität aus. Hierzu gehören die tierischen bzw. menschlichen Produkte wie Kollagen (Khan und Khan 2013), Glykosaminoglykane (Caliari et al. 2011), Chitosan (Lotfi et al. 2011) und Seide (Ji et al. 2013) sowie die pflanzlichen Erzeugnisse wie Agarose, Alginate (Hunt et al. 2010; Dashtdar et al. 2013) und Stärke (Carletti et al. 2011).

Daneben gibt es auch Hybridsysteme, welche sich die Materialeigenschaften sowohl der synthetischen als auch der natürlichen Polymere zu Nutze machen, wie das PolycaprolactonKollagen-Gerüst (Lee et al. 2011), Polyurethan modifiziert mit Seide oder Gelatine (Shen et al. 2013) oder Thiol modifizierte Hyaluronsäure Derivate (Prestwich 2008).

Unter diesen Materialen zur Gerüstherstellung für das Tissue Engineering gehört das Kollagen zu den meist Untersuchten.

Das Kollagen macht bei Säugetieren ca. 30 \% des gesamten Körpereiweißes aus. Als wichtiges Strukturprotein erscheint es hauptsächlich im Stütz- und Bindegewebe innerhalb der Extrazellulärmatrix. Bislang sind 28 unterschiedliche Typen bekannt, wovon das Kollagen vom Typ I am häufigsten vorkommt. Es zählt zu den in Fibrillen angeordneten Erscheinungsformen. Drei linksgewundene $\alpha$-Helices formieren sich zu einer rechtsgewundenen Superhelix, dem Kollagen-Molekül. Aufgebaut ist das Einzelmolekül aus 600-3000 Aminosäuren, die eine Kollagen-spezifische Aminosäure-Sequenz aufweisen (Ramachandran und Sasisekharan 1965).

Im rauen endoplasmatischen Retikulum der Zellen wird ein großes Vorläufermolekül des Kollagens, das tripelhelikale Prokollagen, gebildet und anschließend mittels Exozytose in den Extrazellulärraum befördert. Dort erfolgt die Abspaltung der Propeptide durch zwei Prokollagen-Endopeptidasen, sodass sich die Superhelices mittels Ausbildung kovalenter Querverbindungen zu Fibrillen anordnen können. Diese Fibrillen lagern sich dann zu Kollagenfasern zusammen, die sehr zugfest und kaum dehnbar sind (Harkness 1966). 
Die Kollagen-Biosynthese benötigt Ascorbinsäure (Vitamin C) als Cofaktor für die Hydroxylierung der Aminosäuren Prolin und Lysin zu Hydroxy-Prolin und Hydroxy-Lysin. HydroxyProlin wird benötigt, um Wasserstoffbrückenbindungen zwischen den Kollagen-Helices zu bilden. Hydroxy-Lysin ist wiederum für die Ausbildung kovalenter Querverbindungen zwischen den Ketten notwendig. Beide sind somit für die Stabilität der räumlichen Anordnung und der Zusammenlagerung des Kollagens zuständig. Fehlt Ascorbinsäure bei der Synthese von Kollagen, entsteht minderwertiges Kollagen mit stark reduzierten mechanischen Eigenschaften (Pinnell 1985; Tsutsumi et al. 2012).

Kollagen findet ein breites Einsatzspektrum in der Medizin und Pharmakologie. KollagenSchwämme sind ein beliebtes Mittel zur Hämostase in der Chirurgie, da der Kontakt einzelner Blutbestandteile mit Kollagen die Induktion der Gerinnungskaskade bewirkt (Browder und Litwin 1986). Zudem wird ein positiver Effekt auf die Wundheilung beschrieben (Sabolinski et al. 1996; Seo et al. 2007; Thoma et al. 2012).

Auch in der Ophthalmologie wird Kollagen therapeutisch verwendet. Hier kommen Kollagenhaltige künstliche Tränenersatzflüssigkeit und sowohl therapeutische als auch implantierbare Kollagen-Kontaktlinsen zum Einsatz. Hervorzuheben sei dabei die gute Verträglichkeit des Materials (Poland und Kaufman 1988; Wedge und Rootman 1992).

Ein breites Indikationsgebiet findet sich zudem in der Pharmakologie. Der Gebrauch von Kollagen als Trägerstoff eröffnet in der gezielten pharmazeutischen Dosierungstechnologie diverse Möglichkeiten. So kann damit eine lokalisierte Applikation von speziellen Enzymen direkt an den Wirkort gebracht werden (Rubin et al. 1973; Rössler et al. 1995).

Innerhalb des Tissue Engineerings werden häufig Kollagene als Grundlage für die dreidimensionale Zellkultur verwendet. Dabei wird es in seinen unterschiedlichsten Formen eingesetzt. Als Beispiele seien neben dem vorwiegend verwendeten bovinen Kollagen Typ I auch die denaturierte Form, die Gelatine, aber auch stärker quervernetzte Derivate zu nennen. Für sein vielfältiges Einsatzspektrum steht das Kollagen in verschiedenen Darreichungsformen zur Verfügung: als präformierte kleine Schwämme, Tücher, Streifen, Kügelchen aber auch als Gele in saurer Lösung. Als Grundgerüst kann es zur Herstellung künstlich produzierter keratinisierter Haut, künstlicher Blutgefäße und Klappen dienen (Bell et al. 1983; Koide et al. 1993; Geesin et al. 1996). Zur Bildung von knöchernem Material kann Kollagen ebenfalls verwendet werden. Hier ist besonders der osseoinduktive Effekt von Kollagen-Schwämmen hervorzuheben, die mit dem recombinant human bone morphogenetic protein-2 (rhBMP-2) bestückt worden sind (Murata et al. 1999; Bessa et al. 2008). 
Das Kollagen bringt somit viele Vorteile mit sich. Es ist in Fülle leicht verfügbar und kann mit einfachen Mitteln aus Wirbeltieren gewonnen und gereinigt werden. Wie oben beschrieben hat es einen hämostatischen Effekt. Es besticht durch Nicht-Antigenität, ist nicht toxisch und somit biokompatibel. Es ist biologisch durch den Organismus degradierbar und resorbierbar. Diese Fähigkeit kann durch den Grad der Quervernetzung beliebig modifiziert werden. Dadurch können auf den individuellen Einsatzbereich angepasste Kollagene verwendet werden, die in unterschiedlichste Formen gebracht werden können. Neben diesen zahlreichen Vorteilen werden auch Nachteile des Materials beschrieben und sollten an dieser Stelle erwähnt werden. Die hohen Kosten des reinen Typ I Kollagens seien zunächst zu nennen. In bestimmten Erscheinungsformen kann die Handhabung zudem schwierig sein. Trotz guter Untersuchung kann der Grad des enzymatischen Abbaus nicht vollends vorherbestimmt werden. Da es vorwiegend vom Rind gewonnen wird, sollte als mögliche, extrem seltene Nebenwirkung auch die bovine spongiforme Enzephalopathie (BSE) erwähnt werden (Tabelle 1) (Panduranga Rao 1995).

Tabelle 1: Vor- und Nachteile von Kollagen

\begin{tabular}{|l|l|}
\hline Vorteile & Nachteile \\
\hline in großen Mengen verfügbar & hohe Kosten \\
\hline einfach zu gewinnen & besondere Handhabung \\
\cline { 1 - 1 } hämostatischer Effekt & \multirow{2}{*}{ kungen (BSE) } \\
\cline { 1 - 1 } nicht Antigen & \\
\cline { 1 - 1 } nicht toxisch & \\
\cline { 1 - 1 } biokompatibel & \\
\hline biologisch degradierbar & \\
\cline { 1 - 2 } Eigenschaften können modifiziert werden &
\end{tabular}

Den Nachteilen stehen somit viele relevante klinische Vorteile gegenüber, welche die Verwendung dieses vielseitig untersuchten Materials befürworten. 


\section{D-Kulturkammer:}

Eine dreidimensionale Gewebsherstellung bedarf nebst oben genannter Komponenten auch einer spezialisierten Kultivierungsvorrichtung. Das System sollte alle nötigen Ingredienzen zusammenführen können. Zudem muss sie konstruktionsbedingt eine 3D-Materialherstellung fördern. Entscheidend für eine solche Konstruktion ist, dass zwischen dem Material dieser Kammer und den Zellen sowie dem mechanischen Grundgerüst keine Interaktionen stattfinden. Auf diese Weise kann das Gewebe unversehrt aus der Kulturkammer entnommen werden. Polytetrafluorethylen, auch bekannt als Teflon, weist diese „Antihaft“-Eigenschaft auf (Shao et al. 2009).

\subsubsection{Methoden des Tissue Engineerings}

In diesem Abschnitt sollen einige Methoden verschiedener Arbeitsgruppen zur Herstellung eines dreidimensionalen Weichgewebes aufgeführt werden. Sie verwendeten Zellen, wie Fibroblasten, Epithelzellen, Keratinozyten, Nieren- und Leberzellen. Auf Tissue-EngineeringModelle, welche die Gewinnung von Knochen, Knorpel und nervalen Strukturen erstreben, wird an dieser Stelle nicht eingegangen. Der kurze Abriss soll hier die Varianz innerhalb dieses Forschungsgebietes demonstrieren. Auffallend ist, dass in der Literatur verschiedene Ansätze zum Tissue Engineering vorgestellt werden. Sie unterscheiden sich neben dem Bedarf eines Gerüsts und dessen Material auch im Ausmaß des dafür aufgebrachten Aufwands. Einige Modelle sind mittels einfacher labortechnischer Ausrüstung umsetzbar, andere wiederum benötigen eigens zu diesem Zwecke hergestellte Apparaturen.

Nachfolgend werden die unterschiedlichen Verfahren kurz beschrieben.

a. Die organtypische Explantat-Kultur (Abb. 1): Vitales Gewebe wird entnommen und auf eine semipermeable Membran gegeben, die auf einen metallunterstützten löchrigen Untergrund gelegt wird. Das Gewebe kann dann, umspült von Nährmedium, an der Luft-Flüssigkeits-Grenze wachsen. Das Gewebe kann alternativ auch in ein Hydrogel (Kollagen) gegeben werden. Die Zytoarchitektur und der Zelldifferenzierungsgrad des Ursprungsgewebes bleiben dabei erhalten und dienen als Vorlage für das weitere Zellwachstum. Erprobt wurde diese Methode beispielsweise in der Kultivierung von Anteilen des Hippocampus zur Erforschung von Krankheitsbildern, die sich dort manifestieren (Bissell et al. 2003; Holopainen 2005). 


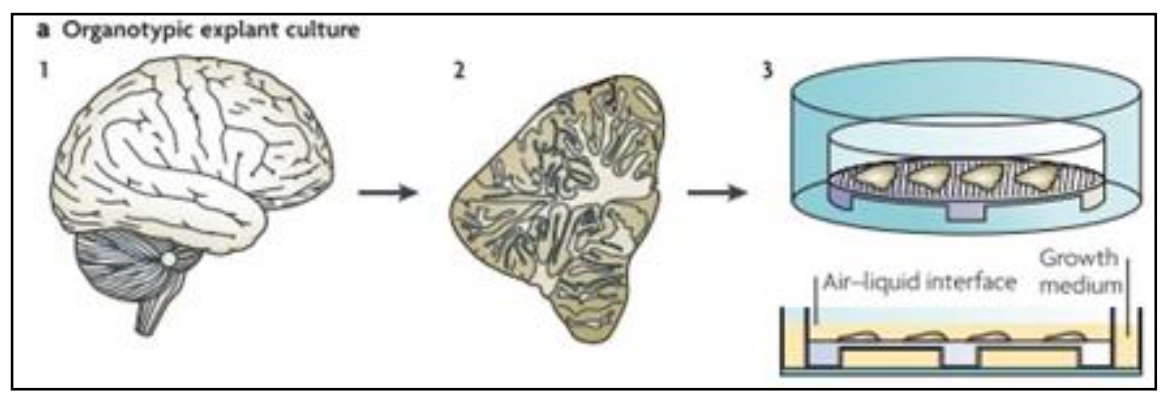

Abbildung 1: Organtypische Explantat Kultur

aus Pampaloni et al. 2007, S. 840

(1.) Aus einem Organ (hier Gehirn) wird (2.) eine dünne Probe entnommen und (3.) auf löchrigem Untergrund in Zellkultur gebracht

b. Das Sphäroid-Modell in unterschiedlichen Ausführungen (Abb. 2): Bei den Sphäroiden handelt sich um kleine Zellaggregate. Diese Methode macht sich das natürliche Aggregationsbedürfnis vieler Zellen zu Nutze. Dazu gibt es unterschiedliche Systeme, um die Zellen zusammenzuführen. Bei einer der Konstruktionen werden Zellen in ein Gefäß mit kleinen Mulden gegeben, wobei sie sich an dem Pol der Vertiefung aneinander lagern. Ein anderes System nutzt weniger die gezielte als die zufällige Zellanheftung. Dabei werden Zellen in eine Vorrichtung abgegeben, die zur Rotation gebracht wird und so die Zellen zusammenführt (Schwarz et al. 1992; Castañeda und Kinne 2000; Kelm et al. 2003; Timmins et al. 2005).

Allerdings können sie zuvor in einem gerüstschaffenden Material wie Kollagen oder Matrigel suspendiert werden. Dabei erreichen sie in ihrer sphäroidalen Konfiguration Durchmesser von einigen Hundert Mikrometern (Bruzewicz et al. 2008).

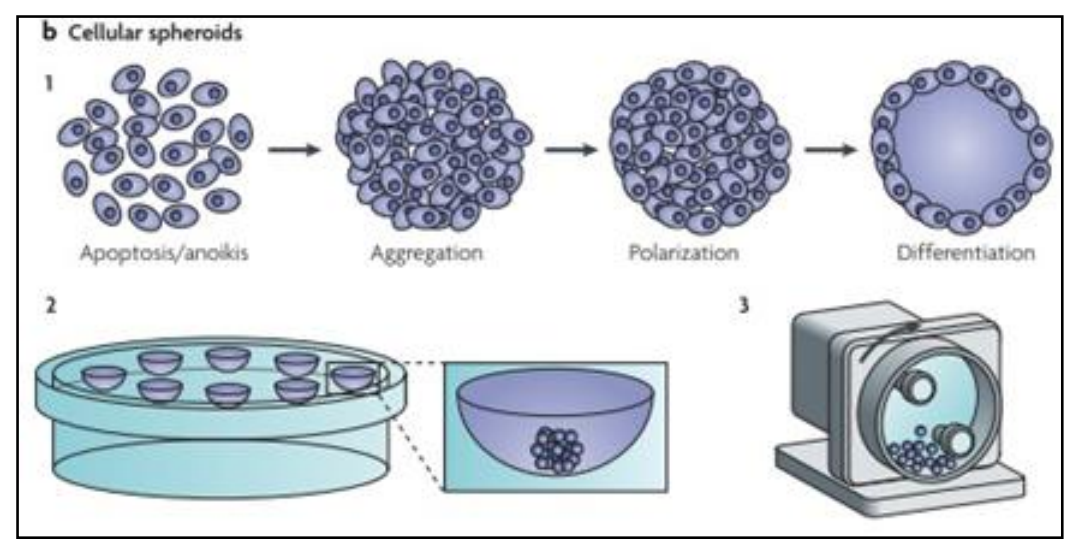

Abbildung 2: Sphäroid-Modell

aus Pampaloni et al. 2007, S. 840

(1.) Zellaggregation hin zu polarisierter Anordnung der Zellen mit Differenzierung und Hohlorganau sbildung. Die Zellaggregation kann durch (2.) Applikation in ein System mit kleinen Mulden oder (3.) ein rotierendes Gefäß induziert werden. 
c. Die einschichtige polarisierte Epithel-Zellkultur (Abb. 3): Die Induktion einer ZellPolarität kann auf zwei Arten geschehen. Bei einer Methode werden die Zellen an einer Luft-Medium-Grenze auf einer mikroporösen Membran appliziert und zeigen nach einiger Zeit eine klare Polarität. Anders können die Zellen auch in ein Extrazellulärmatrix-Gel gegeben werden und formieren sich dabei zu ausgehöhlten, rundlichen Aggregaten, bei denen der apikale Pol nach außen gerichtet ist. Spezielle Zelllinien wie die MDCK-Zellen (Madin-Darby-Canine-Kidney-Zellen) werden hier dazu verwendet, um ein besseres Verständnis für die Ausrichtung von Zellen zu gewinnen (O’Brien et al. 2001).

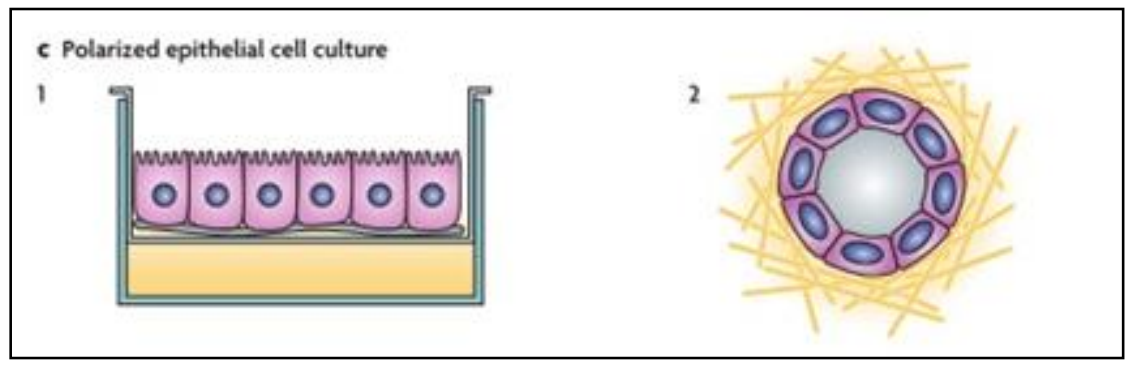

Abbildung 3: Polarisierte Epithel-Zellkultur aus Pampaloni et al. 2007, S. 840

(1.) Zellen auf mikroporöser Membran, zeigen Ausrichtung. (2.) Zellen formieren sich in einem Extrazellulärmatrix-Gel zu einem Hohlorgan.

d. Bei dem Modell zur Herstellung künstlicher Haut (Abb. 4) benötigt man als Grundlage ein feines Netz aus einem resorbierbaren Material (fibrilläres Kollagen, unbehandelt oder modifiziert mit Querverstrebungen). Es wird mit zuvor in Petrischalen kultivierten primären Fibroblasten bedeckt. Nach wenigen Tagen bis Wochen können anschließend Keratinozyten auf die Fibroblasten gegeben werden. Die Keratinozyten können sich zunächst anheften und proliferieren. In einem weiteren Schritt werden die Keratinozyten direkt an die Luft-Medium-Grenze in der Zellkultur gebracht, sodass sie sich gezielt ausrichten können (Bell et al. 1983; Geesin et al. 1996).

Ein ähnliches Modell wurde auf der Grundlage humaner deepidermisierter azellulärer Dermis als Matrize erprobt. Dabei werden menschliche Fibroblasten und Keratinozyten auf der zuvor behandelten Dermis ausgesät. Die Zellen formieren sich nach vorgegebener Inkubationszeit zu einem epithelialisierten Haut-Konstrukt (Ghosh et al. 1997; Harrison et al. 2006). 


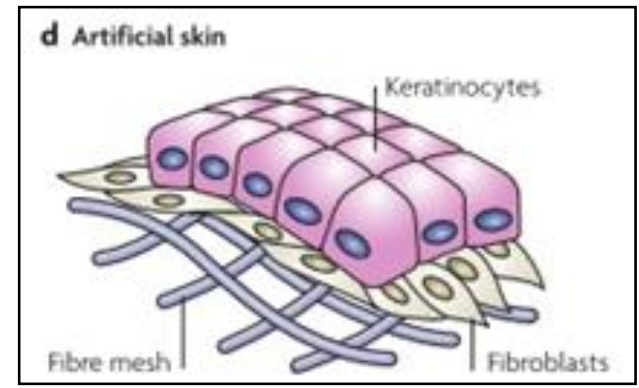

Abbildung 4: künstliche Haut aus Pampaloni et al. 2007, S. 840

Auf einem feinen Netz liegen Fibroblasten, auf diesen liegen zuoberst Keratinozyten.

e. Die Kultur mit einem Mikroträger (Abb. 5) aus Dextran, Gelatine, Glykosaminoglykanen, Gläsern und anderen porösen Polymeren bewirkt eine oberflächliche Anheftung von Zellen an der Außenhülle des Trägers. Die beladenen Mikroträger werden oftmals dann in großen Bioreaktoren in Kultur gehalten. Die Zellen können auf diese dreidimensionale Art der Zellkultur viel effektiver Biosynthese betreiben als in einem zweidimensionalen System. Dieser Aufbau wird in der Regel für die kommerzielle Produktion von speziellen Proteinen, beispielsweise in der Herstellung von Impfstoffen, benutzt (van Wezel 1967; Levine et al. 1977; Varani et al. 1983; Lu et al. 2013).

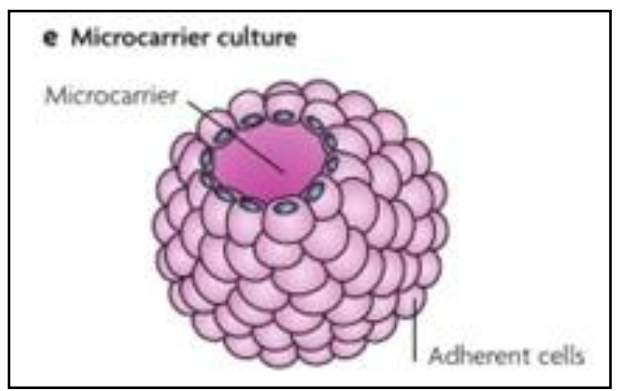

Abbildung 5: Microträger Zellkultur aus Pampaloni et al. 2007, S. 840

Zellen können an einem zentral liegenden Mikroträger adhärieren

f. Das modulare Tissue Engineering (Abb. 6): Eine Zell-Kollagen-Suspension wird dabei in Form zylinderartiger Module gepresst und geschnitten und anschließend mit Epithelzellen bedeckt. Diese Bausteine werden in eine Microfluid-Zellkulturkammer gesetzt. Auf diese Weise können sich die einzelnen Module zusammenlagern und ein Gewebe ausbilden, das von einem Kanalsystem zur Versorgung der Zellen mit Medium/Blut durchzogen ist (McGuigan und Sefton 2007). 


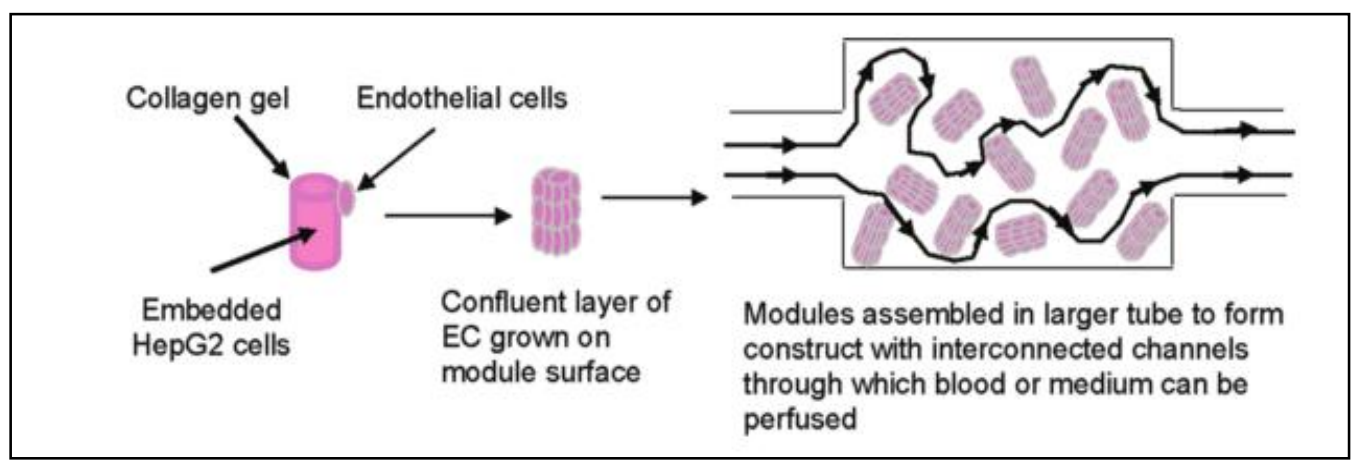

Abbildung 6: Modulares Tissue Engineering

McGuigan und Sefton 2007, S. 1070

In einem Kollagengel eingebettete Hepatozyten werden ummantelt von Epithelzellen. Sie liegen in kleinen Modulen vor. Diese werden anschließend in eine Microfluid-Zellkammer gegeben. Zwischen den Modulen bildet sich ein Kanalsystem.

Es gibt einige Tissue-Engineering-Modelle zur Herstellung von oralem Weichgewebe. Sie unterscheiden sich in der Wahl des mechanischen Grundgerüstes (Scaffold), der verwendeten Zellen und des Versuchsaufbaus. Der Einsatz von allogenen mesenchymalen Stammzellen ist hier weniger relevant. Häufig werden autologe primäre Fibroblasten verwendet (Jhaveri et al. 2010, Dominiak et al. 2010, Dominiak et al. 2012, Köseoğlu 2013). Sie werden aus dem Probandenmund entnommen und ihre Anzahl in Zellkultur expandiert. Anschließend werden sie in eine Polygalactin-Matrix (McGuire und Nunn 2005), eine allogene azelluläre Dermis (Jhaveri et al. 2010) oder eine vorgefertigte Kollagen-Membran bovinen Ursprungs (Dominiak et al. 2012, Köseğolu 2013) gesät. 


\section{Material und Methoden}

\subsection{Studiendesign}

Bei dieser Arbeit handelt es sich um eine experimentelle Studie auf der Grundlage vorliegender primärer humaner Fibroblasten zur Herstellung von Bindegewebe im 3D-TissueEngineering-Modell. Die primären Fibroblasten stammen aus der Gewebedatenbank der Arbeitsgruppe ZIEBOLZ (Ethikantragsnummer 16/6/09). Die Patienten wurden mündlich und schriftlich über die weitere Verwendung der Gewebeproben aufgeklärt und gaben ihr schriftliches Einverständnis. In der Gewebedatenbank der Poliklinik für Präventive Zahnmedizin, Parodontologie und Kariologie befinden sich zu Untersuchungszwecken primäre humane Fibroblasten von 17 Patienten. Für diese Untersuchung wurden dazu zufällig fünf PatientenZelllinien ausgewählt.

Die Gewebeproben mussten zur Gewinnung und Vermehrung von primären Fibroblasten in Zellkultur gegeben werden. Anschließend erfolgte die Überführung der Zellen in das 3DTissue-Engineering-Modell, in dem das Bindegewebe-Konstrukt hergestellt wurde. Dieses Konstrukt wurde anschließend histologisch untersucht. Abbildung 7 zeigt den Aufbau des Studiendesigns.

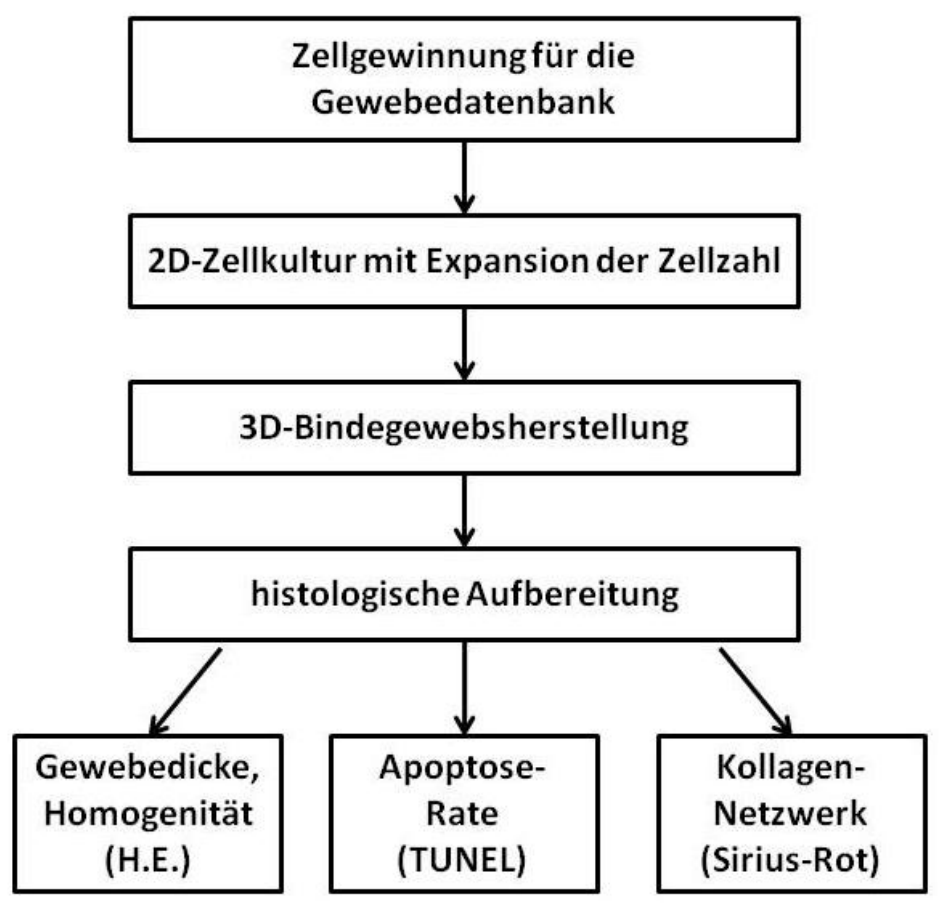

Abbildung 7: Aufbau des Studiendesigns 


\subsection{Zellgewinnung für die Gewebedatenbank}

Bei einem geplanten parodontalchirurgischen Eingriff wurden Gewebeproben aus überwiegend entzündungsfreien Verhältnissen gewonnen. Es handelte sich hierbei um epithelialisiertes Bindegewebe. Für die Versuche sollten primäre Fibroblasten gewonnen und kultiviert werden. Das Gewebe musste dafür in ca. 2 x $2 \mathrm{~mm}$ große Stücke geteilt werden. Anschließend wurde es in 6-Well-Platten (Greiner Bio-One, Frickenhausen) überführt. Für ca. 10 Minuten erfolgte die Inkubation im Brutschrank (Sanyo Electric Biomedical Co., Nenndorf) bei $37^{\circ} \mathrm{C}$ und einer $\mathrm{CO}_{2}$-Sättigung von $5 \%$, sodass sie an den Well-Plattenboden adhärieren konnten. Die 6-Well-Platten wurden behutsam mit dem Zellkulturmedium DMEM (Dulbecco's Modified Eagle Medium; 4,5g Glukose, Gibco Invitrogen Corporation, Karlsruhe) zu einem Drittel gefüllt. Das Zellkulturmedium DMEM war stets zu $10 \%$ mit fetalem Kälber Serum (Biochrom AG, Berlin), zu $2 \%$ mit Gentamycin (Biochrom AG, Berlin), zu $1 \%$ mit Penicillin/Streptomycin (Gibco Invitrogen Corporation, Karlsruhe) und $\mathrm{zu} 1 \% \mathrm{mit}$ Amphotericin B (PAN-Biotech GmbH, Aidenbach) versetzt. Nach Bildung eines dichten Zellrasens um das Gewebe konnten die Gewebestücke verworfen und das Medium abgesaugt werden. Anschließend wurden die Fibroblasten mit PBS (phosphate buffered saline; Gibco Invitrogen Corporation, Karlsruhe) gewaschen. Danach wurden die Zellen nach fünfminütigem Einwirken von Trypsin (Trypsin-EDTA; Gibco Invitrogen Corporation, Karlsruhe) im Brutschrank vom Boden der Well-Platten abgelöst. Die Trypsinwirkung konnte nach Applikation des FKS-haltigen (fetalem Kälber-Serum) Mediums DMEM antagonisiert werden. Anschließend erfolgte bei 1200 UpM (Umdrehungen pro Minute) für 5 Minuten die Zentrifugation (Zentrifuge, Laboratory Centrifuges 2K15C, Sigma Laborzentrifugen GmbH, Osterode am Harz) dieser Zell-Suspension. Der Überstand wurde verworfen, das Zellpallet mit $2 \mathrm{ml}$ Medium suspendiert und dann in eine bereits mit $5 \mathrm{ml}$ aufgefüllte T25-Zellkulturflasche (Greiner Bio-One, Frickenhausen) überführt. Die Gewinnung der Fibroblasten dauerte bis zu diesem Stadium je nach Probe ca. 2-4 Wochen.

Zur Lagerung wurden die Fibroblasten in einem Einfriermedium (Biofreeze, Biochrom AG, Berlin) in Kryoröhrchen (Nunc A/S, Roskilde, Dänemark) in einen Stickstoff-Tank (Chart BioMedical, Ohio, USA) bei $-279^{\circ} \mathrm{C}$ gegeben. Dafür wurden die Zellen aus den Zellkulturflaschen mit Hilfe von Trypsin abgelöst, in Medium suspendiert und anschließend bei 1200 Umdrehungen pro Minute für 5 Minuten zentrifugiert. Nach Verwerfen des Überstandes wurde das Einfriermedium hinzugegeben, sodass die Zellen auf Kryoröhrchen á $1 \mathrm{ml}$ verteilt werden konnten. Für maximal eine Woche konnten diese Röhrchen in einem Einfrierbehelf („Mr. Frosty“, Thermo Fisher Scientific, Langenselbold) in einem $-80{ }^{\circ} \mathrm{C}$ Tiefkühllagergerät 
(Thermo Scientific Inc, Waltham, USA) herunter temperiert und dann zur Lagerung in einen Stickstoffbehälter überführt werden.

\subsection{D-Zellkultur mit Expansion der Zellzahl}

Zur Vorbereitung der 3D-Bindegewebsherstellung mussten die eingefroren humanen Fibroblasten aus der Zelldatenbank (Stickstofftank) entnommen und aufgetaut werden. Zur Druckentlastung mussten die entnommenen Kryoröhrchen leicht geöffnet werden und konnten dann auf Eis temporär gelagert werden. Anschließend wurden die Röhrchen im $37^{\circ} \mathrm{C}$ warmen Wasserbad (Memmert GmbH \& Co. KG, Schwabach) aufgetaut. Vorbereitend wurden $5 \mathrm{ml}$ Kulturmedium in eine T25-Zellkulturflasche gegeben. Nach dem Abpipettieren der Zellsuspension aus dem Kryoröhrchen und Überführen in die Zellkulturflasche wurde das Röhrchen erneut mit $1 \mathrm{ml}$ Medium ausgespült, um die verbliebenen Zellen einzufangen. Die humanen Fibroblasten lagerten so lange im Brutschrank, bis sie auf dem Boden einen dichten Zellrasen mit ca. 80 \%iger Bedeckung der Fläche bildeten. Die Zellproliferation wurde täglich unter einem Lichtmikroskop (Zeiss Axiovert, Carl Zeiss GmbH, Oberkochen) mit zehnfacher Vergrößerung verfolgt. Der Wechsel des Zellkulturmediums DMEM erfolgte alle drei Tage. Erreichten die Zellen eine 80\% ige Konfluenz (Abb. 8), konnten diese von der Zellkulturflasche abgelöst und in eine größere überführt werden.

A.)

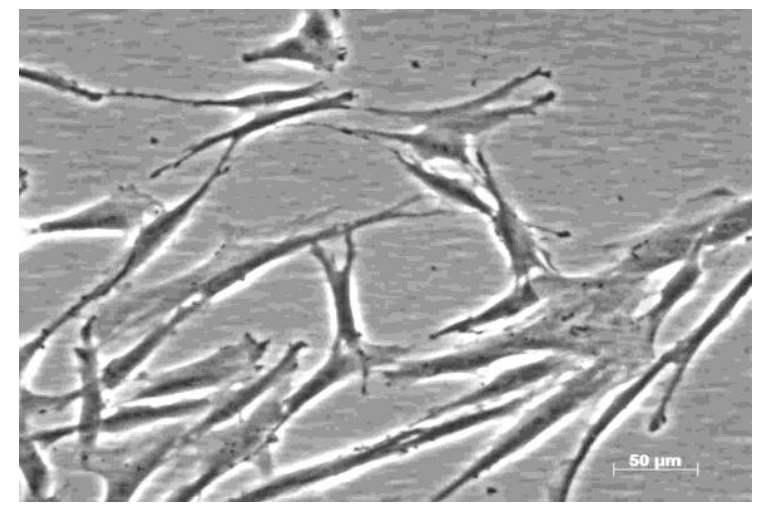

B.)

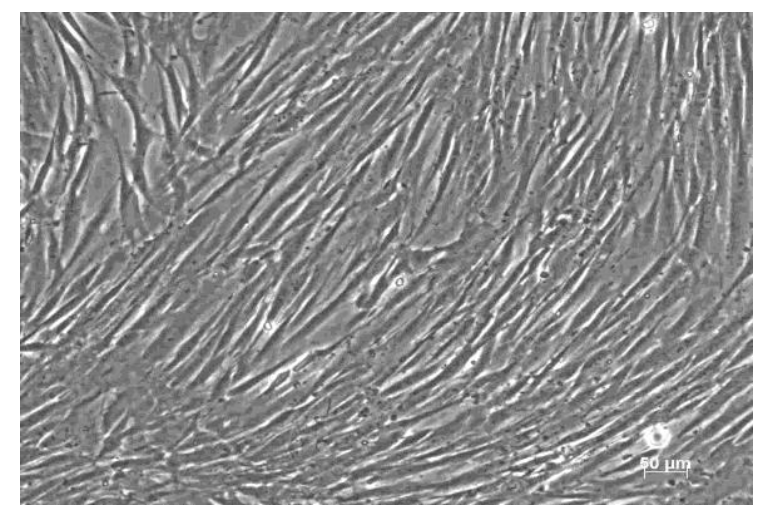

Abbildung 8: primare Fibroblasten in Zellkultur

A: 1 Tag nach Aussähung; B: bei $80 \%$ iger Konfluenz

Zum Ablösen der Zellen wurden nach Waschen mit PBS 2 ml Trypsin-Lösung hinzugegeben und die Zellen dann für fünf Minuten in den Brutschrank gegeben. Mit Hilfe des Lichtmikroskops war zu überprüfen, ob sich die Zellen vom Boden der Zellkulturflasche abgelöst und abgekugelt hatten. Traf dies in ausreichendem Maße zu, konnte die Wirkung des Trypsins durch Hinzugeben von Medium (DMEM) antagonisiert werden. Die Suspension wurde in ein 
15-ml-Falcon-Röhrchen (Becton, Dickinson and Co., New Jersey, USA) gegeben und für 5 Minuten bei 1200 UpM (Umdrehungen pro Minute) zentrifugiert. Nach Verwerfen des Überstandes wurden die Zellen in $2 \mathrm{ml}$ Medium resuspendiert und in eine T75-Zellkulturflasche (Greiner Bio-One, Frickenhausen) gegeben. Wenn auch dieser Flaschenboden zu 80 \% von einem dichten Zellrasen bedeckt war, wurden die Zellen, wie bereits oben beschrieben, abgelöst, zentrufgiert und anschließend in eine T175-Zellkulturflasche (Greiner Bio-One, Frickenhausen) gegeben. Nach erneuter Konfluenz konnten die Fibroblasten im Verhältnis von 1:3 auf drei T175-Zellkulturflaschen aufgeteilt werden.

In der zweidimensionalen Zellkultur wurden definierte Zielzellzahlen nach ca. 2-4 Wochen erreicht und die Zellen konnten anschließend für die dreidimensionale Zellkultur verwendet werden.

\subsection{D-Bindgewebsherstellung}

Zur dreidimensionalen Bindegewebsherstellung bedurfte es neben den oben erwähnten primären humanen Fibroblasten auch anderer Komponenten. Die Zellen mussten zudem in ein Grundgerüst gelagert werden, welches die Anregung der Adhäsion, Proliferation und Aktivierung der Zellen induziert. Aufgrund der außerordentlich gut untersuchten und bewährten Materialeigenschaften kam ein bovines Kollagen-Gel (Collagen Solutions LLC, San Jose, USA) als Grundgerüst zum Einsatz. Für das 3D-Tissue-Engineering wurde eine einfache 3DKulturkammer aus Teflon konstruiert, in die alle hierfür benötigten Komponenten zusammengeführt werden konnten.

\subsubsection{Teflon-Kammer}

Als 3D-Zellkultur-Kammer wurde eine Teflon-Form konstruiert (Abb. 9). Das Material der 3D-Kammer bestand aus Polytetrafluorethylen (Teflon). Die Zellkulturkammer war quadratisch geformt mit einer Kantenlänge von $2 \mathrm{~cm}$ und einer Wandstärke von 0,25 cm (Abb. 9A). Die Höhe der Kammer lag bei 0,8 cm (Abb. 9B). Entlang der Wände waren nach innen hin insgesamt 12 senkrecht stehende Zylinder mit einem Durchmesser von 0,2 cm angeordnet. Die Distanz zwischen diesen Zylindern und den Wänden der Form lag bei $0,15 \mathrm{~cm}$. 
A.)

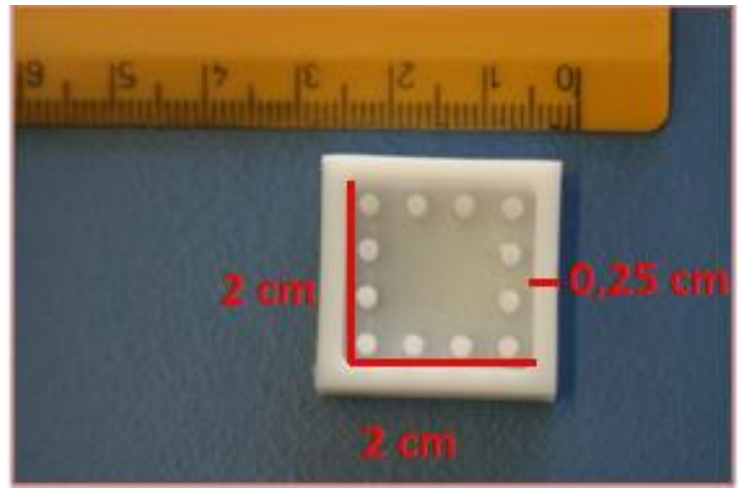

B.)

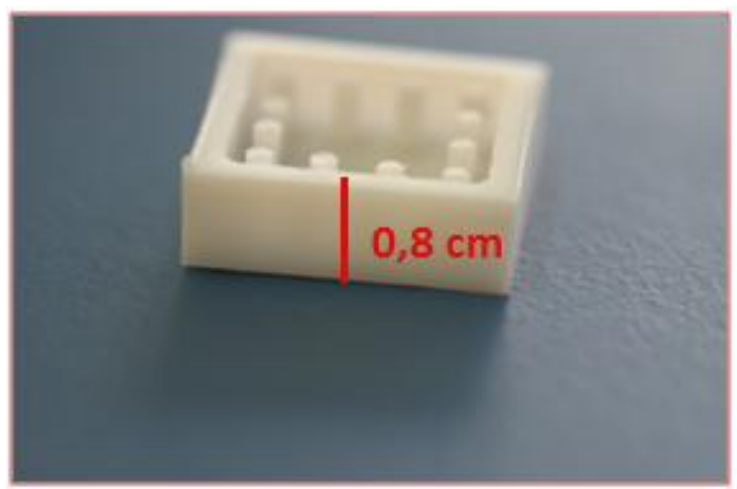

Abbildung 9: Teflon-Kammer mit Einzeichnung der Kantenlängen A: von oben; B: von der Seite

\subsubsection{Grundaufbau des 3D-Modells}

Um die kultivierten primären Fibroblasten in eine dreidimensionale Gewebekultur zu überführen, musste zunächst eine Zell-Kollagen-Suspension hergestellt werden.

Die Zell-Kollagen-Suspension wurde hergestellt aus:

1. Fibroblasten (in Medium gelöst),

2. Kollagen-Gel $(7,25 \mathrm{mg} / \mathrm{ml})$,

3. 2-fach-DMEM und

4. Natriumhydroxid $(0,1 \mathrm{~N})$.

Die Fibroblasten benötigen ein mechanisches Grundgerüst aus Kollagen, um im Weiteren proliferieren zu können. Die Zell-Kollagen-Suspension konnte anschließend in die bereits oben vorgestellte 3D-Kulturkammer (Teflon-Kammer) gefüllt werden.

Für den reibungslosen Versuchsablauf waren unterschiedliche Teil-Arbeitsschritte vorzubereiten:

1. Herstellung von 2-fach-DMEM aus DMEM-Pulver

2. in Medium gelöste Fibroblasten aus der Zellkultur

3. benötigte Materialen auf Eis legen

4. Teflon-Kammer im Glasbehälter bereit legen

Zunächst musste 2-fach-DMEM angesetzt werden. Dafür wurde ein 10-fach-DMEM mittels DMEM-Pulver (Gibco Invitrogen Corporation, Karlsruhe) hergestellt, das dann im Anschluss verdünnt wurde. Für das 2-fach-DMEM wurden das 10-fach-DMEM zu 20 \%, FKS zu $20 \%$, Pen/Strep zu $1 \%$, Amphotericin B zu $1 \%$ und Gentamycin zu $2 \%$ zu destilliertem Wasser hinzugefügt. Die hergestellte Lösung wurde steril filtriert. 
Die Zellsuspension, gelöst in einfachem DMEM, sollte auch in entsprechender Konzentration vorliegen (vgl. dazu Zellkonzentration innerhalb der Zell-Kollagen-Suspension in „Vorversuche“). Dazu mussten die zuvor kultivierten Fibroblasten von den Zellkulturflaschen abgelöst, zentrifugiert und in Medium resuspendiert werden.

Um eine vorzeitige Kondensation des Kollagens zu verhindern, wurden das 2-fach-DMEM, die Zellsuspension, Natriumhydroxid (0,1 N) (Merck KGaA, Darmstadt), das Kollagen-Gel (Collagen Solutions LLC, San Jose, USA) sowie Pipetten auf Eis gelegt. Die Teflon-Form sollte, griffbereit zum Befüllen, in einem sterilen Glasbehälter mit Deckel (Neubert Glas GbR, Geschwenda/Thür) liegen.

In ein 50-ml-Falcon-Röhrchen (Becton, Dickinson and Co., New Jersey, USA), das zuvor auf Eis gelegt worden war, wurden zunächst $463 \mu$ l Kollagen-Gel (11,02 Vol.\%) - ohne Bildung von Bläschen - eingefüllt und daraufhin in gleicher Menge das 2-fach-DMEM. Es war ein Farbumschlag des im Medium enthaltenen Indikators in einen gelblichen (säuerlichen) Bereich $\mathrm{zu}$ beobachten. Zum Puffern der Lösung mussten $90 \mu \mathrm{l}$ 0,1 N Natriumhydroxid $(2,14$ Vol.\%) hinzugegeben werden. Die Farbe des Indikators schlug dann in das für dieses Medium typische Magentarot um. Zum Schluss wurden $3184 \mu 1$ der Zellsuspension (75,81 Vol.\%) beigemengt und vorsichtig mittels Auf- und Abpipettieren mit der restlichen Lösung vermengt. So entstanden $4200 \mu 1$ der Zell-Kollagen-Suspension. Ungefähr $2 \mathrm{ml}$ der Suspension wurden mit der Pipette aufgenommen und zügig in die 3D-Teflon-Kammer so überführt, dass der Spiegel der Suspension leicht den Rand der Form überragte.

Für ca. 15 Minuten wurde das Ganze zum Vorkondensieren unter der Werkbank (Heraeus Holding GmbH, Hanau) belassen. Danach wurde es für weitere 45 Min. im Brutschrank inkubiert, bevor in den Glasbehälter so viel Ascorbinsäure-haltiges Medium geben wurde, dass dieses den Rand der Teflon-Form um ca. 3 mm überragte (Abb. 10). 


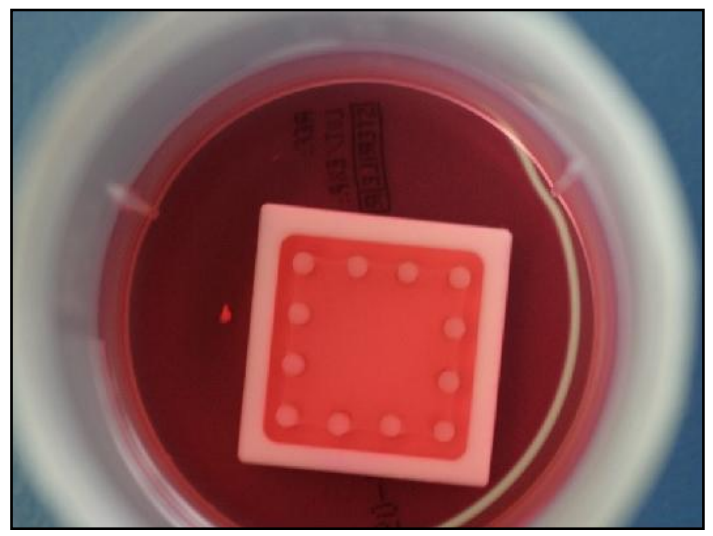

Abbildung 10: 3D- Zellkultur

mit Zell-Kollagen-Suspension beladene Teflon-Kammer, umgeben von 3D-Kultur-Medium

Im Brutschrank konnte die Zell-Kollagen-Suspension dann zum Gewebe-Konstrukt kondensieren. Der Verlauf wurde täglich dokumentiert und das Gewebe-Konstrukt insgesamt für 6 Tage im Brutschrank belassen.

\subsection{Histologische Aufbereitung}

Um die selbst hergestellten Bindegewebskondensate zu untersuchen, war nach der 3DZellkultur eine histologische Analyse durchzuführen.

Mit Hilfe der mikroskopischen Untersuchungen sollten folgende Punkte beurteilt werden:

1. die Homogenität des Bindegewebs-Konstruktes anhand der Hämatoxylin-EosinFärbung

2. der Apoptose-Grad anhand der TUNEL-Färbung

3. die Kollagen-Eigensynthese anhand der Sirius-Rot-Färbung.

Die histologischen Präparate wurden unter einem Lichtmikroskop (Axioscop 2 plus, Carl Zeiss GmbH, Oberkochen) analysiert.

\subsubsection{Vorbereitung für die Histologie}

Das Gewebe-Konstrukt wurde zur histologischen Untersuchung zunächst in 4 \%ig gepuffertem Formalin (CVH Chemie-Vertrieb GmbH \& Co. KG, Hannover) fixiert. Dazu konnte es in der Teflon-Form belassen werden. Nach Absaugen des Mediums und Waschen des Konstruktes mit PBS konnte das Formalin in die Form gegeben werden. Die befüllte Form wurde dann über Nacht bei $4{ }^{\circ} \mathrm{C}$ im Kühlschrank (Liebherr-International Deutschland $\mathrm{GmbH}$, Biberach an der Riss) inkubiert. Danach wurde das Konstrukt aus der Form genommen und mit einer mo- 
deraten Menge PBS in drei Waschgängen von den Überresten der Fixierlösung befreit. In PBS bei $4{ }^{\circ} \mathrm{C}$ gelagert stand das Gewebe-Konstrukt so zur Weiterverarbeitung bereit.

Besonders dünne Bindegewebskondensate (u. a. aus den Vorversuchen) mussten für die histologische Verarbeitung mechanisch stabilisiert werden. Dafür war es in einem Agarose-Gel einzubetten. In einer mit Styropor ausgekleideten Petrischale (Sarstedt Group, Newton, UK) wurde das Gewebe-Konstrukt mit dünnen Nadeln flach zurechtgelegt. Das zuvor angesetzte $2 \%$ ige Agarose-Gel (Cambrex Bio Science, Maine, USA) wurde in der Mikrowelle (Sanyo Electric Co., Osaka) erhitzt und bis auf ca. $40{ }^{\circ} \mathrm{C}$ abgekühlt. Dann konnte das flüssige Agarose-Gel in die vorgefertigte Form mit dem drapierten Konstrukt vorsichtig hinzugegeben werden. Nach Abkühlen auf Raumtemperatur konnte das Gel mit einem Skalpell (Feather Safety Razor Co., Osaka, Japan) eng am Gewebe entlang geschnitten werden. Das so stabilisierte Gewebe konnte dann zwecks Paraffineinbettung entwässert werden. Von dem zuvor fixierten Gewebe-Konstrukt wurde für die Weiterverarbeitung ein $2 \mathrm{~mm}$ schmaler Streifen abgeschnitten.

Für die Einbettung in einen Paraffin-Block musste der Bindegewebsstreifen in einer aufsteigenden Alkoholreihe entwässert werden. Dazu wurde er jeweils für 20 Minuten in $30 \%$-, $50 \%$-, $75 \%$-, $95 \%$ - und zwei Mal in $100 \%$ iges Ethanol gegeben, dann für die gleiche Dauer in ein Ethanol-Xylol (Carl Roth GmbH + Co., Karlsruhe)-Gemisch (1:1) und danach in reines Xylol. Anschließend wurde er für eine halbe Stunde in ein Xylol-Paraffin (Carl Roth GmbH + Co., Karlsruhe)-Gemisch (1:1) eingelegt. Über Nacht wurde dann das Gewebe bei $60{ }^{\circ} \mathrm{C}$, in reinem Paraffin gelagert, inkubiert. Am nächsten Tag konnte dann das Präparat aus dem Paraffin entnommen werden und anschließend auf die später vorgesehene Schnittkante in eine Metallform (Leica Biosystems Nussloch GmbH, Nussloch) gesetzt werden. Die Schnittkante wurde so gewählt, dass später das Gewebe-Konstrukt in seiner gesamten Höhe dargestellt werden konnte. Nach dem Fixieren der Position wurde das Konstrukt mit Paraffin übergossen. In diesem Zustand wurde es auf Eis abgekühlt und anschließend über Nacht bei $4{ }^{\circ} \mathrm{C}$ gelagert. Eine rasche Abkühlung förderte das Ausbilden einer homogenen feinkristallinen Struktur des Paraffins, welches sich dann später besser schneiden ließ.

Das in Paraffin eingebettete Gewebe wurde am Folgetag mittels eines Microtoms (Leica Biosystems Nussloch GmbH, Nussloch) in $5 \mu \mathrm{m}$ dicke Schnitte zerlegt und die Schnitte mit Hilfe eines Wasserbads auf Superfrost-Objektträger (Gerhard Menzel GmbH, Braunschweig) überführt.

Vor der Einfärbung der Präparate wurden diese zunächst entparaffiniert. Dazu mussten die mit Gewebeproben beladenen Objektträger nach dem Schneiden für zwei Tage trocknen, um 
ein Ablösen der Präparate von den Objektträgern zu verhindern. Dann wurden sie für jeweils 15 Minuten zwei Mal in Roti Histol (Carl Roth GmbH + Co., Karlsruhe) gelegt. Anschließend erfolgte die Rehydrierung mittels einer absteigenden Alkoholreihe. Dazu wurde alle 5 Minuten das Alkoholbad gewechselt: Die Rehydrierung erfolgte zwei Mal in 100 \%-, zwei Mal in $96 \%$-, dann in $80 \%$ - und $70 \%$ igem Ethanol. Schließlich wurden sie dann für die gleiche Dauer in destilliertem Wasser und danach in PBS gelagert.

\subsubsection{Ermittlung der Gewebedicke und Homogenität}

Um einen Überblick über das Gewebe-Konstrukt zu gewinnen, wurde mit der HämatoxylinEosin-Färbung gearbeitet. Mit ihrer Hilfe wurde die Gewebedicke und Homogenität der ZellKollagen-Verteilung beurteilt. Die H.E.-Färbung erfolgte am Färbe-Automaten (Sakura Finetec Inc., Torrance, USA) nach unten aufgelistetem Protokoll in Tabelle 2. 
Tabelle 2: H.E.-Färbeprotokoll

\begin{tabular}{|l|l|l|}
\hline Schritt Nr. & Lösung & Zeit in Minuten \\
\hline 1 & Xylol & 5 \\
\hline 2 & Ethanol absolut & 2 \\
\hline 3 & Ethanol 80\% & 2 \\
\hline 4 & Aqua dest. & 2 \\
\hline 5 & Hämalaun & 4 \\
\hline 6 & Aqua dest. & 1 \\
\hline 7 & fließendes Leitungswasser & 15 \\
\hline 8 & Eosin & 7 \\
\hline 9 & Aqua dest. & 1 \\
\hline 10 & Ethanol 60\% & 1 \\
\hline 11 & Ethanol 80\% & 2 \\
\hline 12 & Ethanol absolut & Xylol zur Entnahme \\
\hline 13 & Xylol & 1 \\
\hline 14 & & \\
\hline
\end{tabular}

In der Hämatoxylin-Eosin-Färbung erscheinen die basophilen Zellkerne der Fibroblasten blauviolett, das eosinophile Zytoplasma der Fibroblasten und das Kollagen hingegen rosa (Abb. 11). 


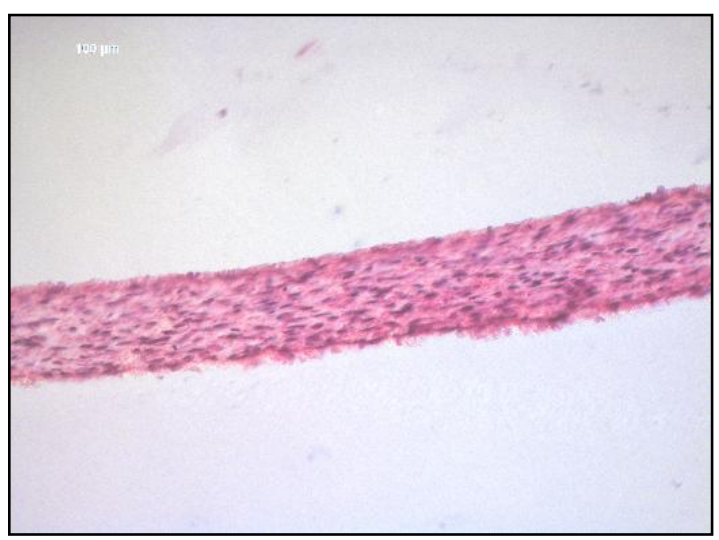

Abbildung 11: H.E.-Färbung; 5-fache Vergrößerung

Präparat in H.E.-Färbung mit dunklen Zellkernen und rosa angefärbtem Zytoplasma und Kollagen

Die H.E.-Färbung diente als Übersichtsfärbung, um das hergestellte Gewebe-Konstrukt anhand unterschiedlicher Kriterien zu beurteilen:

1. Homogenität der Zell-Kollagen-Verteilung innerhalb des Gewebes mit einer erkennbaren Tendenz zur Zellakkumulation an dem oberen/unteren Pol des Präparates. Dabei wird nur vom mikroskopischen Bild ausgegangen, nicht von der Lage des Bindegewebes in der Teflon-Kammer während der Kultur.

2. Fibroblasten-Dichte

3. Erscheinungsform der Fibroblastenkerne, z.B. spindelförmig, rund.

Die variierende Morphologie der hergestellten Bindegewebe-Konstrukte ist in unten abgebildeter Tabelle zusammengefasst (Tab. 3). 
Tabelle 3: variierende Gewebe-Morphologie, 20-fache Vergrößerung, H.E.-Färbung

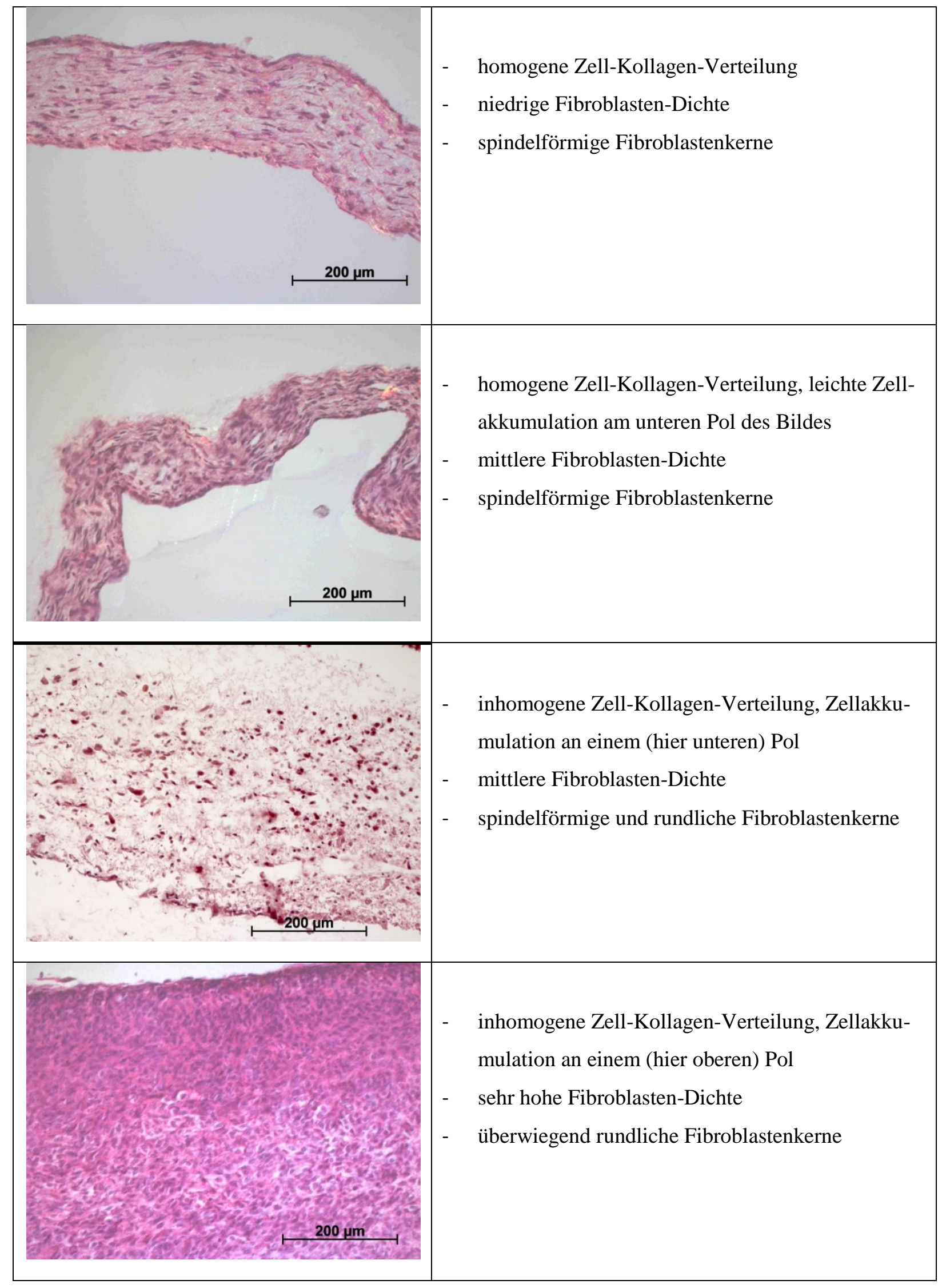




\subsubsection{Bestimmung der Apoptose-Rate}

Um zu ermitteln, ob bei den Versuchen überproportional viel Apoptose induziert wurde, wurde die TUNEL-Färbung (TdT-mediated dUTP nick end labeling) zu Hilfe genommen. DNAStrangbrüche, die während der Apoptose entstanden, konnten in einer enzymatischen Reaktion mit terminaler Desoxynukleotid-Transferase (TdT) mittels Markierung freier 3'-OH-Enden mit modifizierten Nukleotiden identifiziert werden. Das ermöglichte ein Erkennen des eingebauten Fluoresceins mit einem Anti-Fluorescein-Antikörper-Fab-Fragment, das mit alkalischer Phosphatase konjugiert war. Nach der finalen Substratreaktion konnten die dunkel gefärbten Zellen bzw. Zellkerne unter dem Lichtmikroskop begutachtet werden. Diese Färbung war in vier Schritte gegliedert:

1. Das Entwachsen und Rehydrieren,

2. die Permeabilisation,

3. die Färbung und

4. die Signalkonversion.

Das Entwachsen und Rehydrieren der Paraffin-Schnitte erfolgten laut oben zuvor beschriebenem Protokoll.

Zur Permeabilisation wurde eine frisch angesetzte Lösung hergestellt, bestehend aus 0,1\% Triton X-100 (Carl Roth GmbH + Co., Karlsruhe) und 0,1 \% Natriumcitrat (Carl Roth GmbH + Co., Karlsruhe). Nach achtminütiger Einwirkzeit der Permeabilisationslösung auf die Schnitte wurden diese zwei Mal in PBS gewaschen.

Die in der TUNEL-Kit-Packung (Roche Diagnostics GmbH, Mannheim) enthaltenen Röhrchen mit der Enzymlösung und Färbelösung wurden zum Färben verwendet. Zunächst mussten von den $550 \mu 1$ der Färbelösung $100 \mu \mathrm{l}$ für die Negativkontrolle (nachfolgend erläutert) abpipettiert werden. Danach wurde die gesamte Enzymlösung $(50 \mu \mathrm{l}) \mathrm{zu}$ den verbliebenen $450 \mu 1$ Färbelösung gegeben, gut vermischt und diese TUNEL-Lösung bis zum Gebrauch auf Eis gelagert.

Die Objektträger wurden nach Entnahme aus der PBS-Lösung vorsichtig um die Gewebeproben herum getrocknet und in eine Feuchtkammer (Carl Roth GmbH + Co., Karlsruhe) gelegt. Diese wurden anschließend mit je $50 \mu 1$ TUNEL-Lösung benetzt und zur homogenen Verteilung der Lösung mit Parafilm (Bemis Company Inc., Neenah, USA) bedeckt. Die Feuchtkammer wurde dann verschlossen, sodass die Objektträger im Dunkeln für 60 Minuten bei $37^{\circ} \mathrm{C}$ in einen Brutschrank gegeben werden konnten. Danach wurden die Objektträger drei Mal in PBS gewaschen. Zu diesem Zeitpunkt konnten die Proben, benetzt mit einem Tropfen 
PBS, unter einem Fluoreszenzmikroskop analysiert werden (bei einer Anregungswellenlänge von 450-500 nm und einer Nachweiswellenlänge von 515-565 nm).

Als letzten Schritt war die Signalkonversion durchzuführen. Die Objektträger wurden nach Entnahme aus dem PBS-Bad vorsichtig getrocknet und die Converter-AP-Lösung zu je $50 \mu 1$ auf die Proben gegeben und zur homogenen Verteilung mit Parafilm bedeckt. Die verschlossene Feuchtkammer musste für 30 Minuten bei $37^{\circ} \mathrm{C}$ gelagert werden. Im Anschluss wurden die Objektträger drei Mal in PBS gewaschen. Für weitere 10 Minuten waren die mit 50-100 $\mu 1$ der Substratlösung NBT/BCIP (Roche Diagnostics GmbH, Mannheim) benetzten Objektträger bei $15-20{ }^{\circ} \mathrm{C}$ dunkel zu lagern. Zuletzt konnten sie mit einem wässrigen Medium wie PBS eingedeckt werden (Abb. 12).

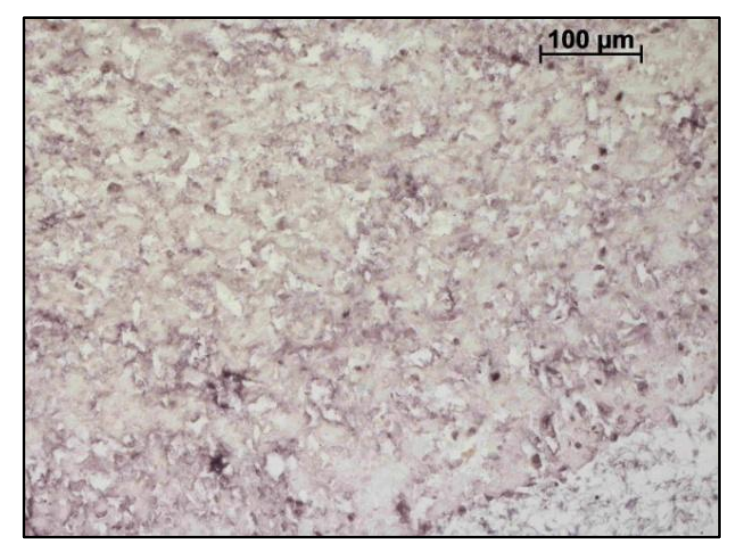

Abbildung 12: Bindegewebe in TUNEL-Färbung; 10-fache Vergrößerung apoptotische Zellkerne dunkel angefärbt

Zusätzlich zu jedem Färbezyklus waren eine Positiv- und eine Negativkontrolle durchzuführen. Für die Positivkontrolle wurden die fixierten und permeabilisierten Objektträger mit DNase I recombinant-Lösung benetzt. Dazu wurde die DNase I (Roche Diagnostics GmbH, Mannheim; $3.000 \mathrm{U} / \mathrm{ml}-3 \mathrm{U} / \mathrm{ml}$ ) gelöst in:

- 50 mM Tris-HCl (Carl Roth GmbH + Co., Karlsruhe), bei pH 7,5

- $10 \mathrm{mM} \mathrm{MgCl} 2$ (Carl Roth $\mathrm{GmbH}+$ Co., Karlsruhe)

- $1 \mathrm{mg} / \mathrm{ml}$ BSA (Carl Roth GmbH + Co., Karlsruhe).

Auf diese Weise wurden DNA-Strangbrüche induziert. Anschließend wurde das Färbeprotokoll, wie oben beschrieben, durchgeführt. Die gesamten Zellkerne mussten nach diesem Procedere angefärbt sein (Tab. 4, Positivkontrolle). 
Tabelle 4: unterschiedliche Apoptose-Raten; 10-fache Vergrößerung; TUNEL-Färbung

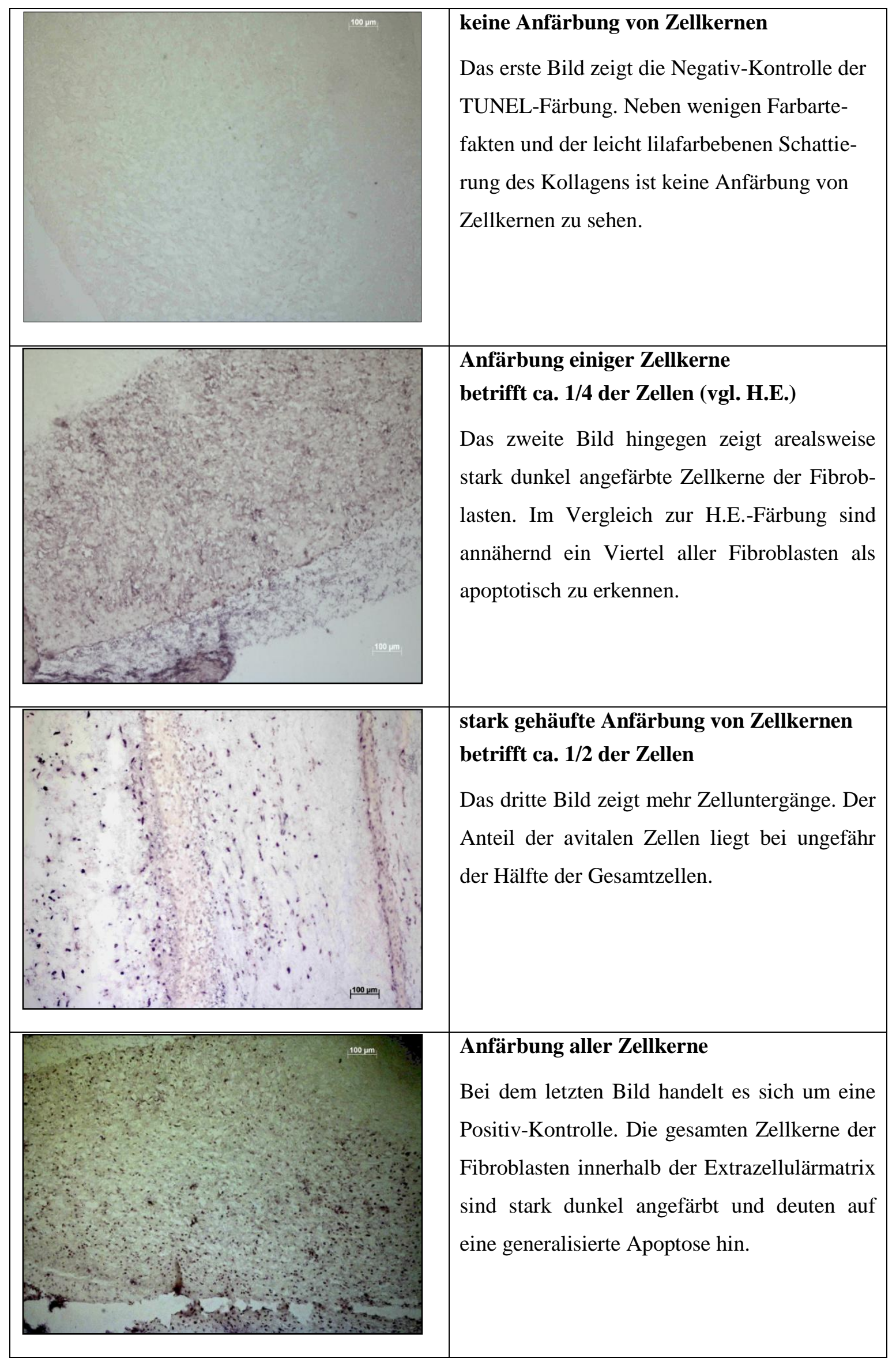


Die Negativkontrolle wurde durchgeführt, indem die reine Färbelösung und nicht die mit dem Enzym versetze TUNEL-Lösung während des Färbeprotokolls verwendet wurde. Hier durften bei Betrachtung unter dem Lichtmikroskop keine apoptotischen (angefärbten) Zellkerne zu sehen sein, denn es fehlte das Enzym terminale Deoxynucleotid-Transferase, welches die Färbung katalysierte (Tab. 4, Negativkontrolle) (Sgonc et al. 1994).

Die in Tabelle 4 abgebildeten mikroskopischen Präparate demonstrieren unterschiedliche Apoptose-Raten. Sie wurden mit einer 10-fachen Vergrößerung aufgenommen. Diese Vergrößerung sorgte für eine Übersicht über den Querschnitt des Gewebe-Konstrukts. Zur späteren Untersuchung wurde eine 20-fache Vergrößerung eingestellt. Zudem wurden die Bilder zur Relationsbestimmung der apoptotischen zu den vitalen Zellen mit der H.E.-Färbung des jeweiligen Präparats verglichen.

\subsubsection{Untersuchung des Kollagen-Netzwerks}

Um das Kollagen-Netzwerk zu untersuchen, wurde eine Sirius-Rot-Färbung vorgenommen.

Bei Sirius-Rot handelt es sich um einen stark anionischen Farbstoff, der Kollagen anfärbt, indem er über seine Sulfonsäure-Gruppen mit den basischen Gruppen der Kollagen-Moleküle reagiert. Die Farbmoleküle lagern sich so an die Kollagenfasern an, dass sich ihre Längsachse parallel zu der des Kollagens anordnet. Diese parallele Ausrichtung der Farbmoleküle zu den Kollagenfasern bewirkt eine verstärkte Doppelbrechung, die hochspezifisch für das Kollagen ist (Junqueira et al. 1979). Unter einem Durchlicht-Mikroskop werden neben dem Kollagen weitere Strukturen rötlich angefärbt. Allerdings ist die Doppelbrechung unter einem Kreuzpolarisationsfilter typisch für Kollagen, ausgenommen Kollagen-Typ IV. Dicke oder auch sehr dicht gepackte Kollagenfasern haben höhere Wellenlängen und erscheinen gelb bis rot und die dünneren Fasern erscheinen grün unter Kreuzpolarisation (Dayan et al. 1989; Trau et al. 1991). Die Abbildung 13 zeigt ein Präparat in Sirius-Rot-Färbung. Diese farbliche Darstellung präsentiert sich unter einem Kreuzpolarisationsfilter. Sie unterscheidet sich von der Farbpräsentation rein mit Durchlicht und ohne Filter.

Die Färbelösung wurde frisch angesetzt. Dazu wurden in $500 \mathrm{ml}$ phlegmatisierter Pikrinsäure 0,5 g (Fluka Chemie GmbH, Steinheim) Direktrot 80 (Sigma Aldrich Chemie GmbH, Steinheim) gelöst (0,1\%ig). Der pH-Wert musste mit $2 \mathrm{M} \mathrm{NaOH}$ (Natriumhydroxid) (Merck KGaA, Darmstadt) auf 2,0 eingestellt werden. Der Lösung mussten Pikrinsäure-Kristalle beigemengt werden, um eine gesättigte Lösung herzustellen. Zudem wurde eine 0,5 \%ige Essig- 
säure-Lösung (AppliChem GmbH, Darmstadt; $5 \mathrm{ml}$ Essigsäure in 1 Liter dest. Wasser) zum Waschen bereitgestellt.

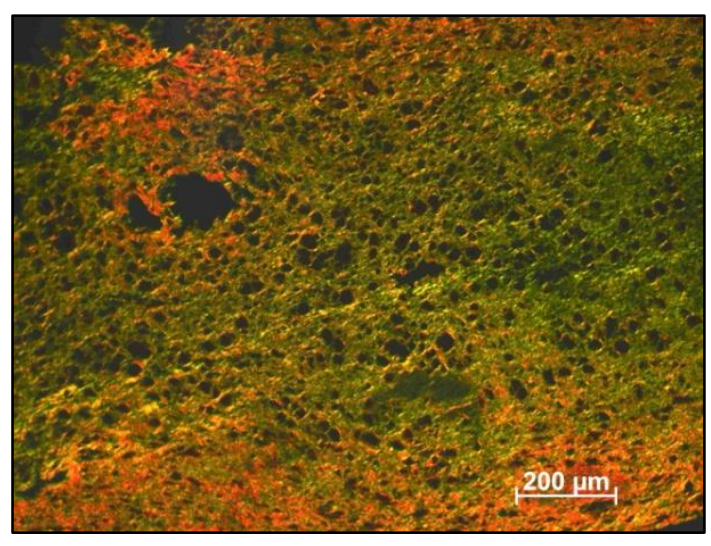

Abbildung 13: Sirius-Rot-Färbung unter Kreuzpolarisationsfilter; 10-fache Vergrößerung

Um später die Fibroblasten zu detektieren, wurden nach erfolgter Entparaffinierung der Schnitte die Zellkerne für 5 Minuten in Mayers Hämalaun (Carl Roth GmbH + Co, Karlsruhe) eingelegt und für 10 Minuten unter fließendem Leitungswasser gespült. Für eine Stunde wurden dann die Objektträger in der Pikrinsäure-Sirius-Rot-Lösung gelagert und anschließend zwei Mal für jeweils fünf Minuten in das verdünnte Essigsäure-Bad gegeben. Danach mussten die Proben drei Mal á fünf Minuten in 100 \%igem Ethanol gewaschen werden. AbschlieBend wurden die Proben dann für mindestens fünf Minuten in Roticlear (Carl Roth GmbH + Co, Karlsruhe) gelegt und dann mit Roti-Histokit II (Carl Roth GmbH + Co, Karlsruhe) eingedeckt. 


\subsection{Vorversuche}

Um optimale Bedingungen zur Herstellung des dreidimensionalen Gewebe-Konstrukts zu ermitteln, wurden drei Vorversuche durchgeführt. Der unter Punkt 3.4.2 aufgeführte „Grundaufbau des 3D-Modells“ (Seite 19) sollte dadurch in Details modifiziert werden, um sichere Ergebnisse zu erzielen zu können.

\subsubsection{Protokoll-Modifikationen}

Die unten aufgeführten Variationen des Versuchsprotokolls (beschrieben unter 3.4.2 „Grundaufbau des 3D-Modells“, Seite 19) beschäftigten sich mit den folgenden Fragestellungen:

1. optimale Zellkonzentration innerhalb der Zell-Kollagen-Suspension

2. Erhöhung der Dicke durch Mehrfachapplikation der Zell-Kollagen-Suspension

3. Nutzen von Ascorbinsäure-haltigem 3D-Zellkulturmedium

Im Anschluss an diese Vorversuche sollten die hergestellten Gewebe-Konstrukte histologisch untersucht werden, um das Protokoll für die Hauptversuche auch in den Feinheiten abschließend definieren zu können.

\section{Bestimmung der Zellkonzentrationen innerhalb der Zell-Kollagen-Suspension:}

Aus drei unterschiedlichen Konzentrationen der Zellsuspension wurde die geeignetste Konzentration für die Versuchsanordnung ermittelt. Hierzu wurde laut des vorab beschriebenen Protokolls vorgegangen. Verändert wurde lediglich die Zellanzahl pro Milliliter in der Zellsuspension. Es wurden Konzentrationen von 1 Mio. Zellen/ml und 2,5 Mio. Zellen/ml sowie 5 Mio. Zellen/ml verwendet. Der Versuch wurde zwei Mal unter den gleichen Bedingungen durchgeführt.

\section{Erhöhung der Gewebedicke durch Mehrfachapplikation:}

Ein weiterer Vorversuch beschäftigte sich mit der Fragestellung der Beeinflussbarkeit der Dicke des neu gewonnenen Gewebes. Die ersten Vorversuche zeigten eine Gewebedicke von ca. $100 \mu \mathrm{m}$, die es im Folgenden zu erhöhen galt.

Dazu wurde eine doppelte Applikation der Zell-Kollagen-Suspension vorgenommen. Der Versuchsablauf folgte weitgehend dem bekannten Protokoll. Nach Füllen der Teflon-Form wurde eine Stunde gewartet, um danach Medium hinzuzugeben. Die Form wurde dann über Nacht in den Brutschrank gegeben. Am Folgetag wurde das Medium vorsichtig abgesaugt 
ohne das frisch kondensierte Gewebe-Konstrukt zu verletzen. Anschließend wurde zunächst eine neu angesetzte Zell-Kollagen-Suspension behutsam an alle vier Ecken der Form gegeben, sodass die Suspension sowohl unter als auch über das zuletzt gebildete Konstrukt fließen konnte. Nach einstündiger Kondensation im Brutschrank wurde der Behälter, in dem sich die Form befand, mit Medium aufgefüllt. Das Ganze wurde dann für weitere drei Tage im Brutschrank inkubiert.

Die dreifache Applikation der Suspension wurde ebenfalls untersucht. Das Vorgehen glich dem der doppelten Applikation bis auf die Anzahl der Schichtung. Die Zell-KollagenSuspension wurde an drei aufeinander folgenden Tagen abgegeben und das Gewebe für insgesamt 6 Tage im Brutschrank inkubiert.

\section{Ermittlung des Nutzens von Ascorbinsäure im 3D-Zellkulturmedium:}

Die Literatur beschreibt den positiven Effekt von Ascorbinsäure (Vitamin C) auf die Kollagen-Eigensynthese von Fibroblasten (Pinnell 1985; Tsutsumi et al. 2012). Als Cofaktor der Hydroxylierungsreaktion unterstützt sie die Ausbildung der räumlichen Struktur und Stabilität des Kollagens.

Um diesen Einfluss auch auf die verwendeten primären Fibroblasten zu ermitteln, wurde ein Vorversuch durchgeführt. Im Stadium der 3D-Zellkultur wurden zwei parallel laufende ZellKollagen-Kondensate (vom selben Patienten stammend) im Stadium der 3D-Kultur mit unterschiedlichen Medien versorgt. Bei einem der beiden Kondensate handelte es sich um das Standard-Zellkulturmedium DMEM; beim anderen wurde DMEM mit Ascorbinsäure (SigmaAldrich Chemie GmbH, Steinheim) in einer Konzentration von 0,5 mmol/l angereichert. Der Versuch wurde bei einfacher Applikation der Zell-Kollagen-Suspension mit einer ZellKonzentration von $2,5 \times 10^{6}$ Zellen/ml vorgenommen.

\subsubsection{Ergebnisse der Vorversuche}

Die gebildeten Gewebe-Konstrukte aus den Vorversuchen wurden histologisch untersucht, um die Auswirkungen der Protokoll-Modifikationen zu untersuchen.

\section{a. Homogenität und Gewebedicke}

Die Gewebeproben aus den Vorversuchen mit variierenden Zellkonzentration (1/2,5/5 Mio. Zellen/ml Zell-Kollagen-Suspension) wurden anhand der H.E.-Färbung untersucht. 
- $\quad$ Konzentration von 1 Mio. Zellen/ml Zell-Kollagen-Suspension: Die Gewebeproben zeigten eine homogene Zell-Kollagen-Verteilung, eine niedrige Fibroblasten-Dichte und spindelförmige Fibroblastenkerne.

- Konzentration von 2,5 Mio. Zellen/ml Zell-Kollagen-Suspension: Das BindegewebeKonstrukt imponierte mit einer höheren Zell-Dichte und einer leichten Tendenz zur polarisierten Anordnung.

- $\quad$ Konzentration 5 Mio. Zellen/ml Zell-Kollagen-Suspension: Die Proben unterschieden sich zu den anderen in der hohen Dichte der Fibroblastenanordnung, der überwiegend rundlichen Form der Zellkerne sowie der deutlichen Akkumulation an einem Pol.

Auch die Gewebeproben aus den Versuchen der Mehrfachapplikation der Zell-KollagenSuspension wurden unter Zuhilfenahme der H.E.-Färbung untersucht. Die Proben aus der Doppel- und auch Dreifachapplikation zeigten eine überwiegend homogene Zell-KollagenAnordnung. Partiell fanden sich Areale mit Fibroblasten, die sich zu einem Pol orientierten. In Bereichen mit höherer Fibroblasten-Akkumulation waren die Zellkerne rundlich/kubisch, in anderen wiederum gestreckt und spindelförmig.

Bei einfacher Abgabe der Suspension in die Teflon-Kammer betrug die Gewebsdicke im Durchschnitt $100 \mu \mathrm{m}$. Durch die Mehrfachapplikation wurde diese, wie zuvor postuliert, um ein Vielfaches gesteigert. So betrug die durchschnittliche Gewebsdicke bei Doppelapplikation ca. $1000 \mu \mathrm{m}$ und bei Dreifachapplikation ca. $1300 \mu \mathrm{m}$.

\section{b. Apoptose-Rate}

Die Untersuchung des Apoptose-Grades der Gewebeproben mit variierender Zellkonzentration und Mehrfachapplikation wurde mit Hilfe der TUNEL-Färbung vorgenommen.

Hier erfolgte keine quantitative computergestützte Auswertung, sondern vielmehr eine Blickuntersuchung mit Einordnung des Apoptose-Grades.

Ziel der Einfärbung war es, massive Zelluntergänge festzustellen, um diese für die Hauptversuche $\mathrm{zu}$ vermeiden und das Protokoll daran anzupassen. Wie oben beschrieben wurde der Versuchsablauf variiert, um die Grenzen des Experiments auszuloten. Verändert wurden die Zellkonzentration pro Milliliter in der Zell-Kollagen-Suspension sowie die Mehrfachapplikation der Suspension. Die TUNEL-Färbung half bei der Einschätzung der Vitalität des Gewebes. 
Die Analyse der Proben aus den Vorversuchen mit der variierenden Zellkonzentration in der Zell-Kollagen-Suspension veranschaulichte die Apoptose innerhalb der GewebeKonstrukte. Die Apoptose-Rate war in Relation zur Zellzahl einheitlich niedrig. Maximal ein Viertel der in der H.E.-Färbung gesichteten Fibroblasten zeigten in der TUNEL-Färbung ein apoptotisches Geschehen.

Die Proben aus der Mehrfachapplikation der Zell-Kollagen-Suspension imponierten überwiegend mit einem niedrigen Apoptose-Grad von ca. einem Viertel der Zellen -sowohl in der Doppel- als auch in der Dreifachapplikation.

Es wurde festgestellt, dass in keinem der Vorversuche eine überschießende Apoptose nachgewiesen werden konnte. Somit konnte angenommen werden, dass diese Modifikationen des Hauptprotokolls mit wenig Zelluntergang umsetzbar waren. Dies ist wahrscheinlich dadurch zu erklären, dass neben der Zellproliferation auch ein Zelluntergang zum natürlichen Gewebeumsatz gehört.

\section{c. Kollagen-Netzwerk}

Die zuvor beschriebene Sirius-Rot-Färbung half bei der Auswertung dieses Vorversuches.

Die Doppelbrechung unter einem Kreuzpolarisationsfilter ist typisch für Kollagen. So haben dicke (aber auch sehr dicht gepackte) Fasern höhere Wellenlängen und erscheinen unter Kreuzpolarisation rot und die dünneren Fasern grün. Unter diesem Aspekt konnten histologisch aufbereitete Präparate auf die roten und grünen Anteile untersucht werden. Die rot angefärbten dicken Kollagenfasern entsprachen dem verwendeten bovinen Kollagen. Abbildung 14 zeigt beispielhaft dieses Bild beim Vorversuch ohne Ascorbinsäure.
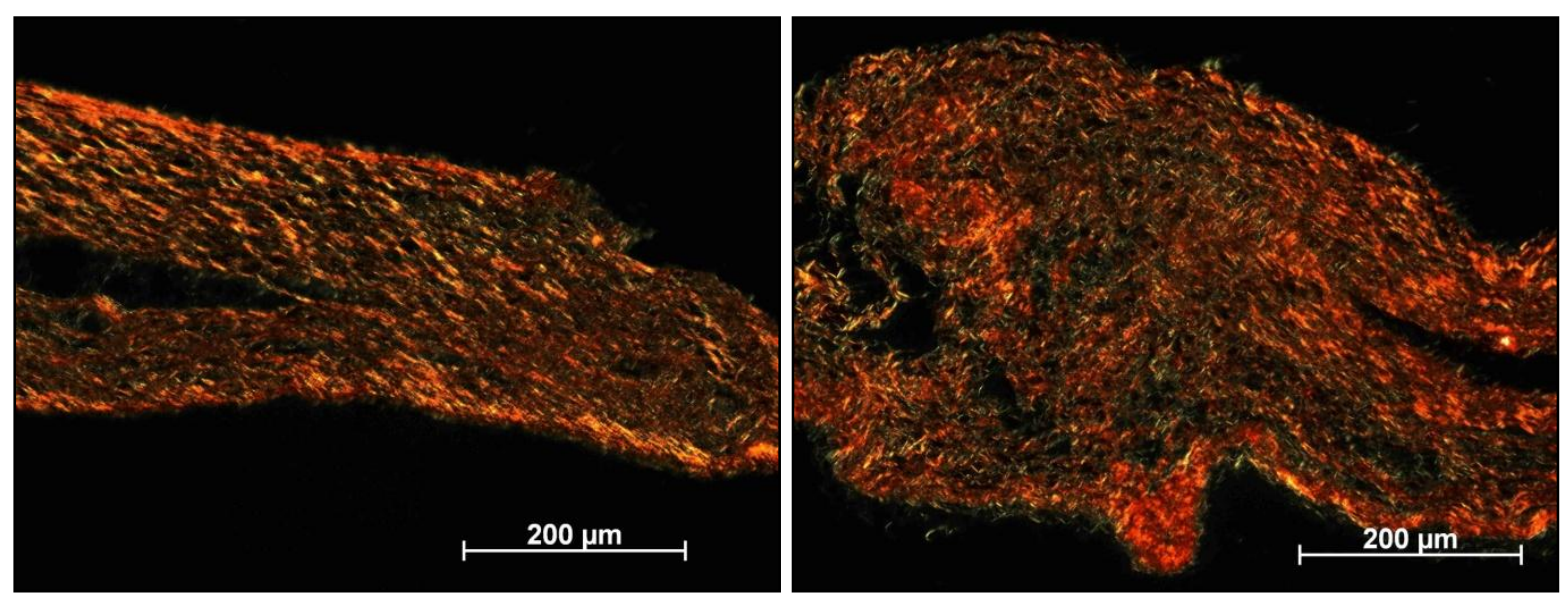

Abbildung 14: Bindegewebe ohne Einfluss von Ascorbinsäure 20-fache Vergrößerung; Sirius-Rot-Färbung 
Die grünen Areale stellten dünne Fasern dar. Sie waren ,jung“ und hatten sich noch nicht zu dicken Strängen formiert. Hierbei handelte es sich um das eigensynthetisierte Kollagen der Fibroblasten. Abbildung 15 zeigt beispielhaft dieses Bild bei Zusatz von Ascorbinsäure.

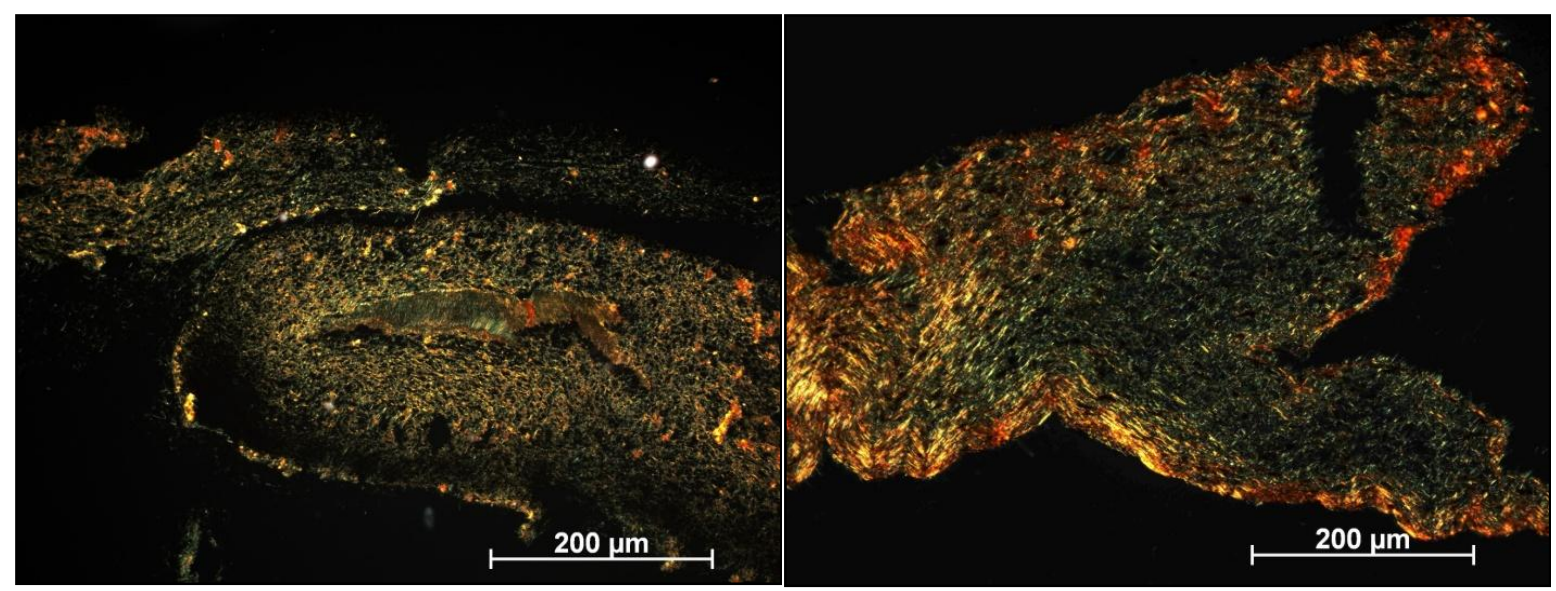

Abbildung 15: Bindegewebe mit Einfluss von Ascorbinsäure 20-fache Vergrößerung; Sirius-Rot-Färbung

Ein positiver Effekt der Ascorbinsäure auf die Kollagen-Eigensynthese war zu erkennen. Betrachtete man die unterschiedlichen Präparate, so ließ sich deutlich unterscheiden, welche Gewebskondensate unter dem Einfluss von Ascorbinsäure-haltigem DMEM kultiviert worden waren (Abb. 14; Abb. 15).

Es zeigte sich, dass die verwendeten primären Fibroblasten - neben dem Abbau des Fremdkollagens mittels Kollagenasen - in der Lage waren, mit Ascorbinsäure als Cofaktor, Eigenkollagen zu synthetisieren. So bauten sie die künstlich geschaffene bovine Matrix ab und ersetzen diese durch eine autolog gebildete.

\subsubsection{Schlussfolgerung aus den Vorversuchen}

Folgende Schlussfolgerungen konnten aus den Vorversuchen gezogen werden.

1. Die Variation der Zellkonzentration innerhalb der Zell-Kollagen-Suspension zeigte in Relation keine überschießenden apoptotischen Vorgänge. Die niedrigste Zellkonzentration lag bei 1 Mio. Zellen/ml. Es wurde angenommen, dass die Konzentration zu niedrig ist, um innerhalb kurzer Zeit in ausreichendem Maße eine eigene stabile Extrazellulärmatrix zu synthetisieren. Die höchste Zellkonzentration (5 Mio. Zellen/ml) zeigte im H.E.-Schnitt kein typisches Aussehen von Bindegewebe. Die Begutachtung zeigte bei einer Konzentration von 2,5 Mio. Zellen/ml Suspension eine homogene 
Zell-Kollagen-Verteilung und keine übermäßige Apoptose. Aus diesem Grund wurde auch im Hauptversuch diese Konzentration gewählt.

2. Die Mehrfachschichtung zeigte bei Doppel- und Dreifachapplikation ähnliche Ergebnisse, allerdings mit dem Unterschied, dass die Gewebedicke bei Dreifachapplikation höher war. Deshalb wurde sich zugunsten der höheren Dicken für die Dreifachschichtung entschieden.

3. Der positive Einfluss von Ascorbinsäure auf die Kollagen-Eigensynthese der Fibroblasten während der 3D-Zellkultur war deutlich zu sehen. Daher wurden die Hauptversuche im Stadium der 3D-Zellkultur mit Ascorbinsäure-haltigem Medium durchgeführt. 


\subsection{Versuchsanordnung der Hauptversuche}

Für die Hauptversuche hat sich nach Auswertung der Vorversuche als Methode der Wahl ergeben:

1. das Verwenden einer Zellkonzentration von 2,5 Mio. Zellen/ml

2. die Dreifachapplikation der Zell-Kollagen-Suspension

3. ein Ascorbinsäure-Zusatz zum 3D-Medium von 0,5 mmol.

Die restliche Versuchsanordnung wurde, wie in „Grundaufbau des 3D-Modells“ beschrieben, beibehalten.

Die Hauptversuche wurden mit Fibroblasten von fünf verschiedenen Patienten durchgeführt. Von jedem Patienten wurde der Versuch in Doppelbestimmung angelegt, so dass insgesamt 10 Bindegewebskondensate hergestellt wurden. Diese sind im Anschluss histologisch Aufbereitet und untersucht worden.

Neben der Bewertung von Übereinstimmungen und Abweichungen zwischen den 10 Patienten-Proben konnten auch solche innerhalb ein und demselben Patienten untersucht werden.

Die Untersuchungsmethoden entsprachen denen der Vorversuche. Dabei wurden sie nach den Kriterien in Tabelle 5 analysiert.

Tabelle 5: Untersuchungskriterien und Methoden für die Hauptversuche

\begin{tabular}{|l|l|l|}
\hline Nr. & Kriterien & Methode \\
\hline $\mathbf{1}$ & Gewebegröße/-fläche & $\begin{array}{l}\text { makroskopisch, direkte Längenmessung } \\
\text { mit einem Lineal }\end{array}$ \\
\hline $\mathbf{2}$ & Gewebedicke & $\begin{array}{l}\text { mikroskopisch mit der H.E.-Färbung, } \\
\text { computerunterstützt }\end{array}$ \\
\hline $\mathbf{3}$ & $\begin{array}{l}\text { Homogenität der Zell-Kollagen-Verteilung } \\
\text { (mit Fibroblasten-Dichte und -Morphologie) }\end{array}$ & Mikroskopisch mit der H.E.-Färbung \\
\hline $\mathbf{4}$ & Apoptose-Rate & mikroskopisch mit der TUNEL-Färbung \\
\hline $\mathbf{5}$ & Kollagen-Eigensynthese & $\begin{array}{l}\text { mikroskopisch mit der Sirius-Rot- } \\
\text { Färbung unter einem Kreuzpolarisations- } \\
\text { filter }\end{array}$ \\
\hline
\end{tabular}




\section{Ergebnisse}

\subsection{Gewebegröße}

Die Größe des Gewebe-Konstrukts wurde durch direkte Messung mit Hilfe eines Lineals nach Fixierung ermittelt (Abb. 16).

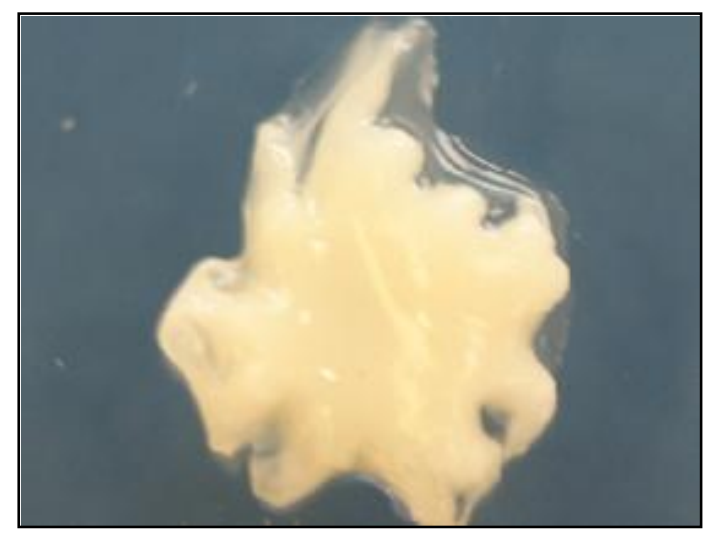

Abbildung 16: Bindegewebe nach 6 Tagen Kondensation

Die erreichten Gewebegrößen sind in Tabelle 6 aufgeführt. Die Kantenlängen wurden miteinander multipliziert, um die Fläche des Gewebes zu ermitteln. Der durchschnittliche Flächeninhalt der Gewebe-Konstrukte lag bei 1,69 $\mathrm{cm}^{2}$ (Tab. 6).

Tabelle 6: Gewebegrößen

\begin{tabular}{|c|c|c|}
\hline Patient & $\mathbf{A}$ & $\mathbf{B}$ \\
\hline $\mathbf{I}$ & $1,6 \mathrm{~cm} \mathrm{x} 1,3 \mathrm{~cm}=2,08 \mathrm{~cm}^{2}$ & $1,4 \mathrm{~cm} \times 1,3 \mathrm{~cm}=1,82 \mathrm{~cm}^{2}$ \\
\hline II & $1,2 \mathrm{~cm} \mathrm{x} 1,1 \mathrm{~cm}=1,32 \mathrm{~cm}^{2}$ & $0,8 \mathrm{~cm} \times 0,9 \mathrm{~cm}=0,72 \mathrm{~cm}^{2}$ \\
\hline III & $1,5 \mathrm{~cm} \mathrm{x} 1,4 \mathrm{~cm}=2,1 \mathrm{~cm}^{2}$ & $1,4 \mathrm{~cm} \times 1,1 \mathrm{~cm}=1,54 \mathrm{~cm}^{2}$ \\
\hline IV & $1,3 \mathrm{~cm} \mathrm{x} 1,1 \mathrm{~cm}=1,43 \mathrm{~cm}^{2}$ & $1,3 \mathrm{~cm} \times 1,3 \mathrm{~cm}=1,69 \mathrm{~cm}^{2}$ \\
\hline $\mathbf{V}$ & $1,5 \mathrm{~cm} \mathrm{x} 1,4 \mathrm{~cm}=2,1 \mathrm{~cm}^{2}$ & $1,6 \mathrm{~cm} \times 1,3 \mathrm{~cm}=2,08 \mathrm{~cm}^{2}$ \\
\hline
\end{tabular}

[beide Proben eines Pateinten (Doppelbestimmung) gegenüber gestellt, mit „A“ und „B“ gekennzeichnet] 


\subsection{Gewebedicke und Homogenität}

Mit der H.E.-Färbung wurden die folgenden Kriterien untersucht:

1. Gewebedicke der Konstrukte

2. Homogenität der Zell-Kollagen-Verteilung

3. Fibroblasten-Dichte und -Morphologie.

Hinsichtlich dieser Parameter wurden die in Doppelbestimmung hergestellten GewebeKonstrukte aller fünf Patienten analysiert (insgesamt 10 Proben).

Beim ersten Bild (links und rechts) handelt es sich jeweils um eine Übersichtsaufnahme im H.E.-Schnitt in einer 5-fachen Vergrößerung. Mit der Computersoftware des Mikroskops wurden Maßstabsbalken (auch bei allen anderen Präparaten) eingefügt und die Gewebedicke der Konstrukte mittels Längenbestimmung eingezeichnet. Das zweite Bild (links und rechts) zeigt stets das Präparat in der H.E.-Färbung in 20-facher Vergrößerung, um dadurch die Zellanordnung zu verdeutlichen.

\section{Patient 1:}

Die 5-fache Vergrößerung der beiden Patientenproben 1A (links; Abb. 17, 1A) und 1B (rechts; Abb. 17, 1B) zeigt eine Übersichtsaufnahme über das jeweilige Präparat. Die Längenmessung innerhalb der Präparate ergab eine Gewebedicke von 1587,71 $\mu \mathrm{m}$ in Probe A und $1875,68 \mu \mathrm{m}$ in Probe B.

Der Überblick über die äußere Form zeigte eine Schichtung von 5 Lagen. Innerhalb der Schichten waren die Zellen überwiegend homogenen angeordnet. Die zentralste Schicht war gleichzeitig auch die dickste. Dies ließ sich in beiden Proben $(A+B)$ festsetellen.

1A.)

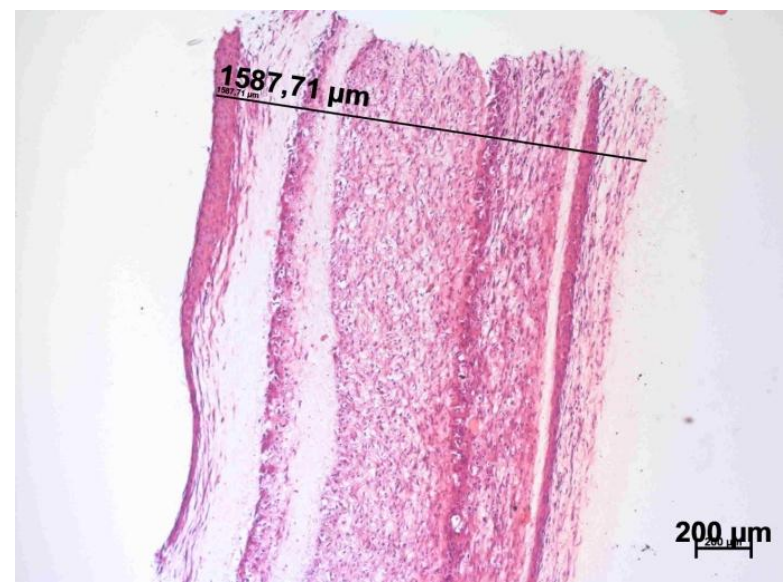

1B.)

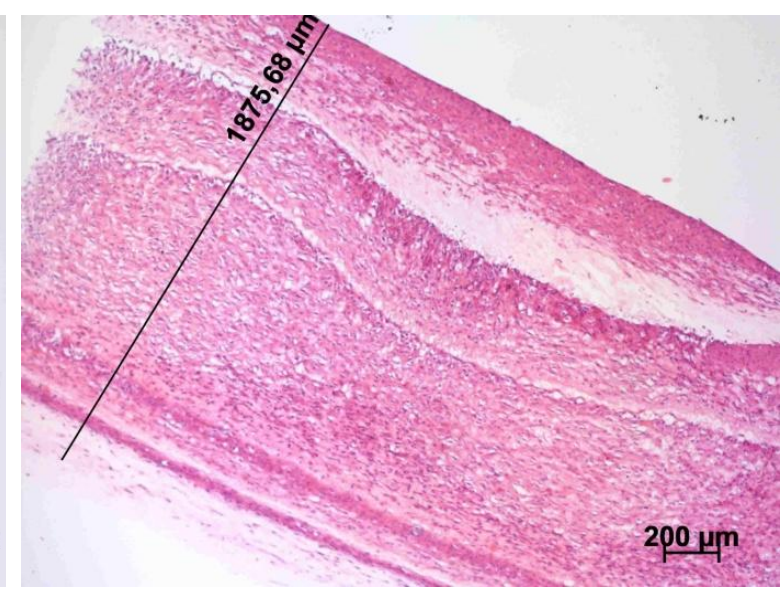

Abbildung 17: Patient 1; H.E.-Färbung; 5-fache Vergrößerung 1A: Patient 1A, mit Längenbestimmung; 1B: Patient 1B, mit Längenbestimmung 
Bei der näheren Betrachtung der Präparate mit einer höhreren Vergrößerung (Abb. 18, 1A und 1B) zeigte sich, dass der stärker angefärbte, etwas Fibroblasten-dichtere Bereich relativ dünn war und der Rest der Schicht eher homogen verlief. Die Fibroblasten und ihre Kerne imponierten durch ihre typische Spindelform und waren in vielen Ebenen angeschnitten. Der zu erahnende Verlauf der Kollagenfasern, in dem die Zellen eingebetten waren, erschien geflechtartig und ohne ersichtliche Zugrichtung.

1A.)

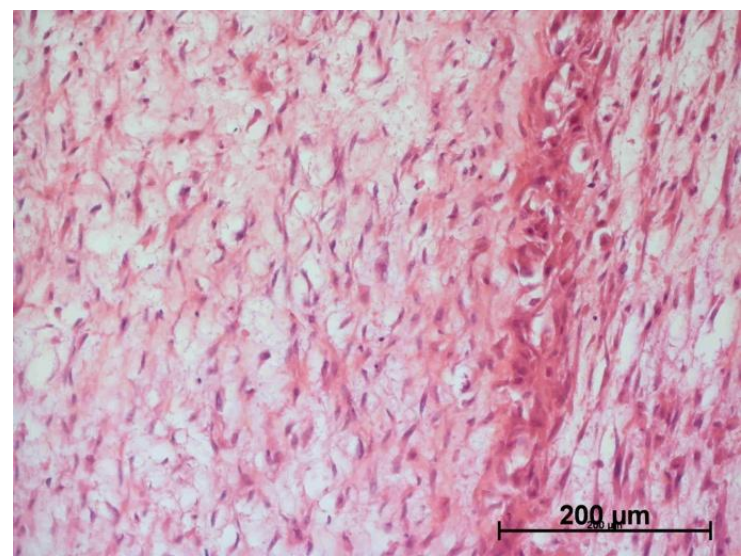

1B.)

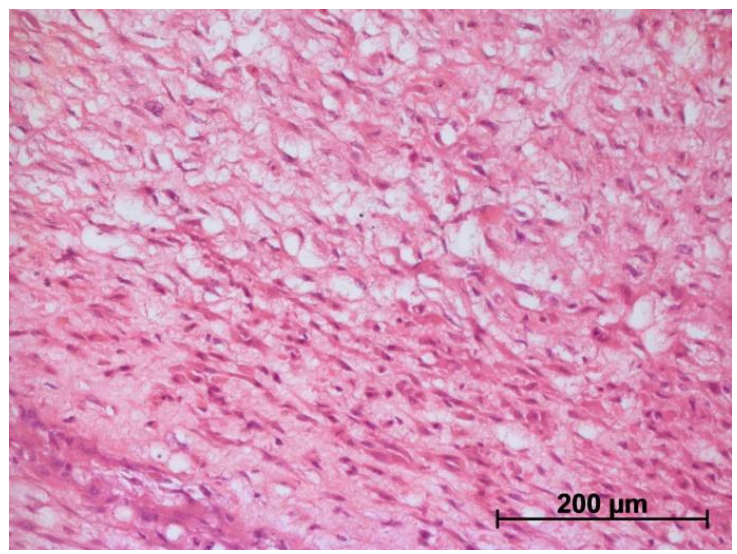

Abbildung 18: Patient 1; H.E.-Färbung; 20-fache Vergrößerung 1A: Patient 1A; 1B: Patient. 1B

\section{Patient 2:}

Die Gewebedicke der Probe A des Patienten 2 (Abb. 19, 2A) zeigte in der Übersichtsaufnahme eine Höhe von 1510,72 $\mu \mathrm{m}$ und die Probe B 1926,14 $\mu \mathrm{m}$ (Abb. 19, 2B). Das GewebeKonstrukt imponierte in Abbildung 18, 2A mit vier Schichten und in Abbildung 19, $2 \mathrm{~B}$ mit zweien.

2A.)

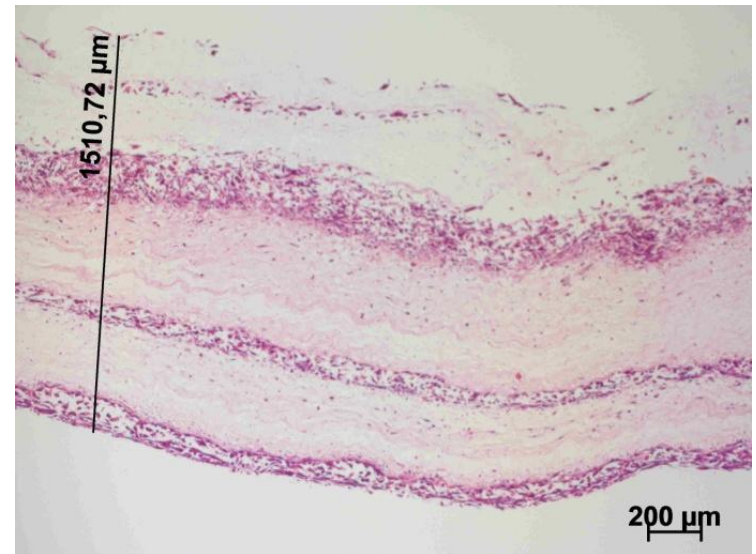

2B.)

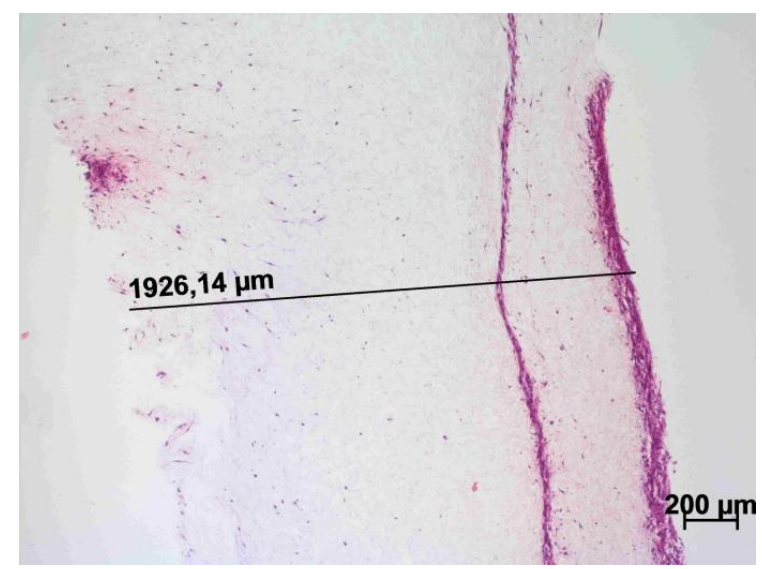

Abbildung 19: Patient 2; H.E.-Färbung; 5-fache Vergrößerung

2A: Patient 2A, mit Längenbestimmung; 2B: Patient 2B, mit Längenbestimmung 
Die Betrachtung bei stärkerer Vergrößerung demonstrierte in Probe A (Abb. 20, 2B) eine deutliche Akkumulation der Fibroblasten an einem Pol der Schicht. Noch deutlicher war diese inhomogene Zellverteilung in Probe B des Patienten 2 (Abb. 20, 2B) zu sehen. Ein großer Anteil der Fibroblasten sammelte sich in einem Saum, an den sich ein kollagenreiches und zellarmes Gebiet anschloss. Die Fibroblastenkerne der zellreichen Areale waren rundlich/kubisch, die der zellarmen Anteile spindelförmig. Die Kollagenfasern der Probe A (Abb. 20, 2A) verliefen eher wellenförmig, die Fasern der Probe B (Abb. 20, 2B) eher geflechtförmig.

2A.)

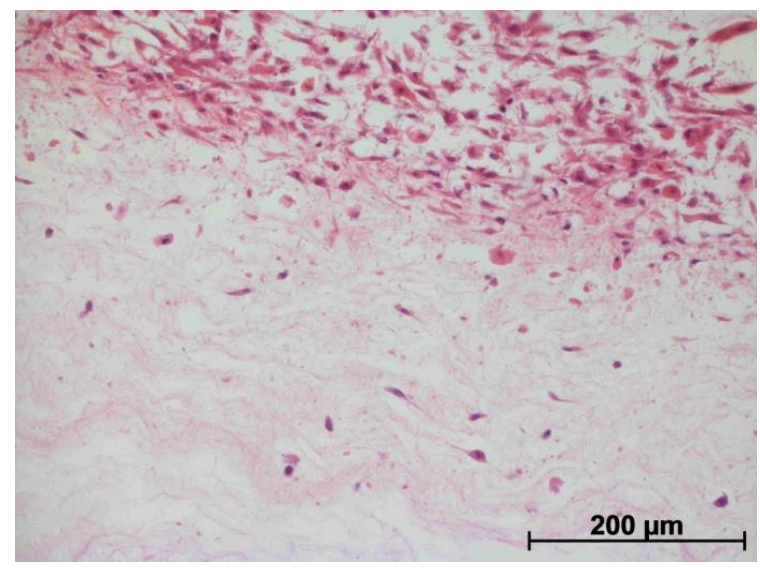

2B.)

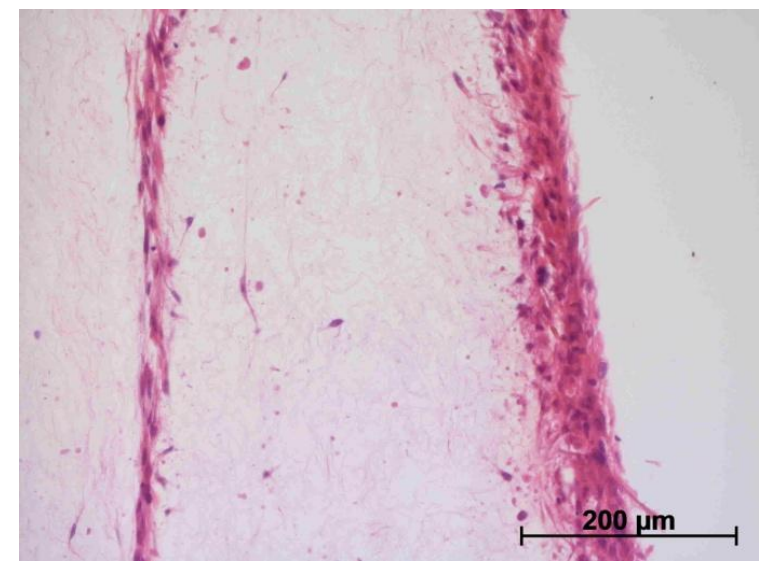

Abbildung 20: Patient 2; H.E.-Färbung; 20-fache Vergrößerung 2A: Patient 2A; 2B: Patient 2B

\section{Patient 3:}

Die computerunterstütze Längenmessung ergab für Probe A eine Dicke von 1719,88 $\mu \mathrm{m}$ (Abb. 21, 3A) und Probe B von 1969,73 $\mu \mathrm{m}$ (Abb. 21, 3B).

Die Übersichtsaufnahme des Konstruktes des dritten Patienten präsentierte in Probe A (Abb. 21, 3A) eine Vier-Schichtung, in Probe B (Abb. 21, 3B) eine Fünf-Schichtung. Die im Bild rechtsseitig gelegene Schicht der Abbildung 21, 3A zeigte die zellreichste Lage. Die anderen drei Schichten waren zellärmer. Die Abbildung 21, 3B imponierte mit einer überwiegend homogenen Verteilung der Zellen innerhalb der Schichten. Die zentralste Schicht war auch die Dickste. 

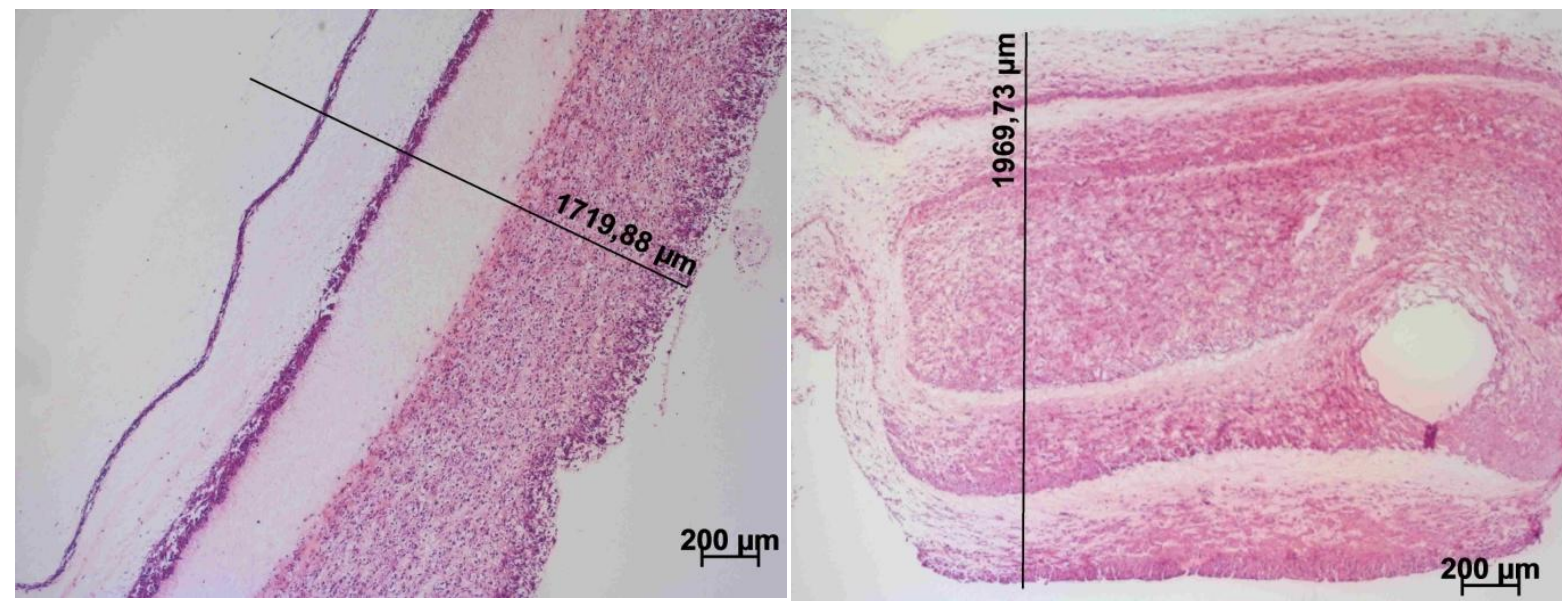

Abbildung 21: Patient 3; H.E.-Färbung; 5-fache Vergrößerung

3A: Patient 3A, mit Längenbestimmung; 3B: Patient 3B, mit Längenbestimmung

Eine inhomogene Verteilung in der Zellanordnung war in Probe A und B zu erkennen (Abb. 22, 3A und 3B). Die Fibroblastenkerne in Probe $\mathrm{A}$ waren in zellreichen Gebieten rundlich/kubisch und in zellarmen spindelförmig. Die rechtsseitig im Bild liegende Schicht hat eine hohe Fibroblastendichte und überwiegend spindelförmige Zellkerne. Probe B imponierte durch überwiegend fibroblastenreiche Lagen des Gewebe-Konstrukts mit vornehmlich spindelförmigen Kernen. Die kollagenen Fasern beider Proben verliefen überwiegend geflechtförmig und zeigten keine erkennbare Zugrichtung.

3A.)

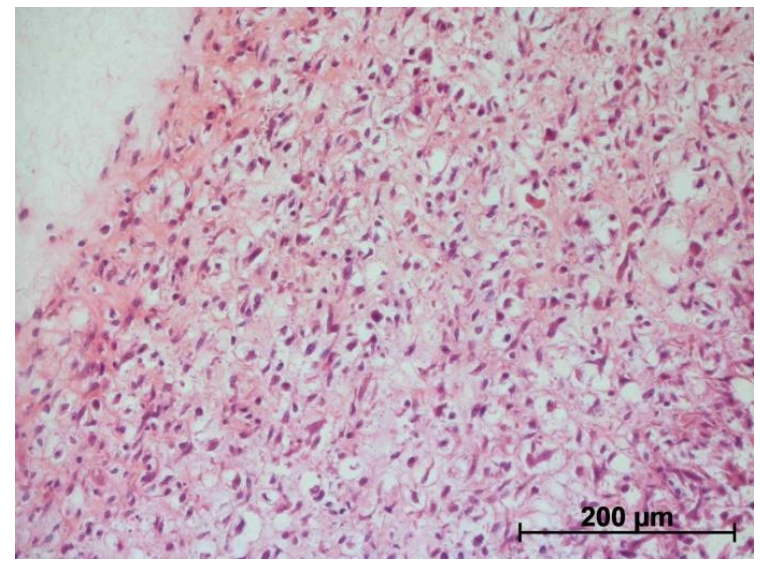

3B.)

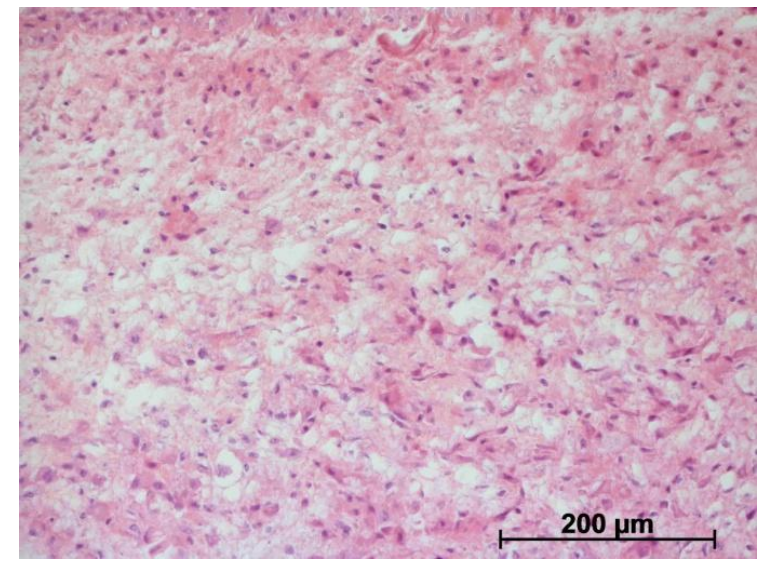

Abbildung 22: Patient 3; H.E.-Färbung; 20-fache Vergrößerung

3A: Patient 3A; 3B: Patient 3B

\section{Patient 4:}

Die computergestützte Längenmessung der Höhe der Präparate ergab Werte von 1320,30 $\mu \mathrm{m}$ für Probe A (Abb. 23, 4A) und 1603,19 $\mu$ m für B (Abb. 23, 4B). Beide Proben des Patienten 4 zeigten in der Aufnahme der Übersichtsvergrößerung (Abb. 23, 4A und 4B) eine dreifache 
Schichtung. Die Fibroblastenakkumulation an einem Pol der Schicht war bei beiden Proben sehr deutlich ausgeprägt. Probe A zeigte zudem partiell ausgerissene Areale der Zellanhäufung (oberer Rand im Bild; Abb. 23, 4A), welche nicht in die Beurteilung einflossen, sie wurden als histologisches Artefakt eingeordnet.

4A.)

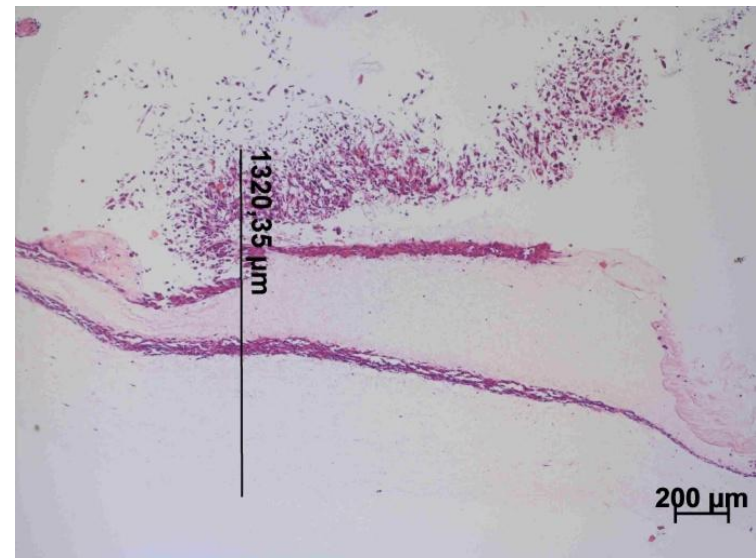

4B.)

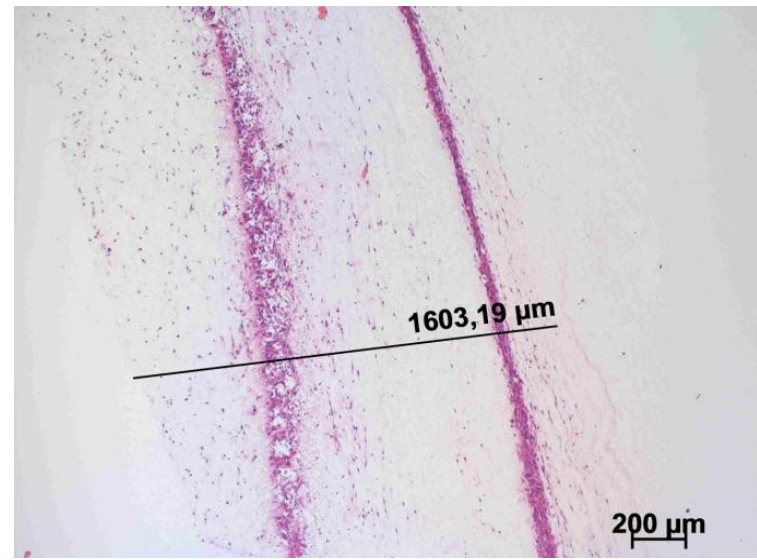

Abbildung 23: Patient 4; H.E.-Färbung; 5-fache Vergrößerung

4A: Patient 4A, mit Längenbestimmung; 4B: Patient 4B, mit Längenbestimmung

Innerhalb der Schichten fanden sich zellreiche und zellarme Areale. Die Zellverteilung in Probe B (Abb. 24, 4B) war mittelgradig homogener als in Probe A (Abb. 24, 4A). In den zellreichen Anteilen fanden sich vermehrt rundlich/kubische Fibroblastenkerne, in den zellarmen gehäuft spindelförmige Kerne. Die zu erkennenden kollagen Fasern beider Bindegewebsproben waren geflechtartig angeordnet.

4A.)

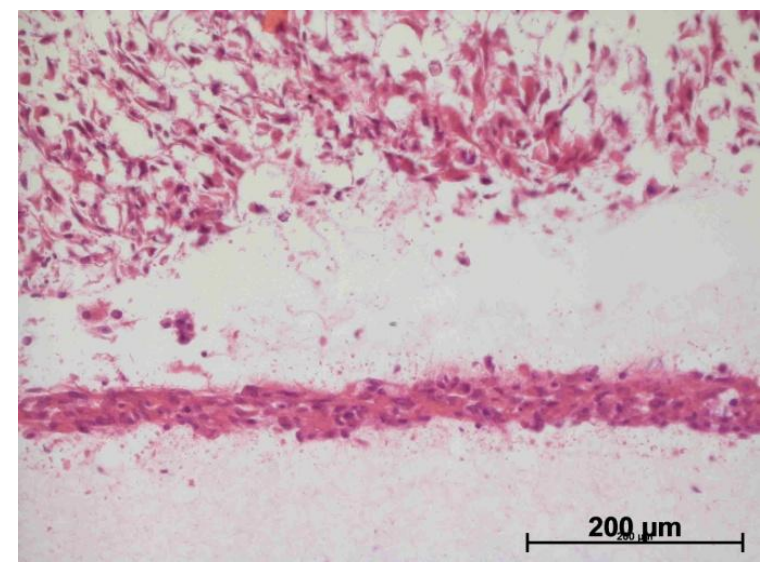

4B.)

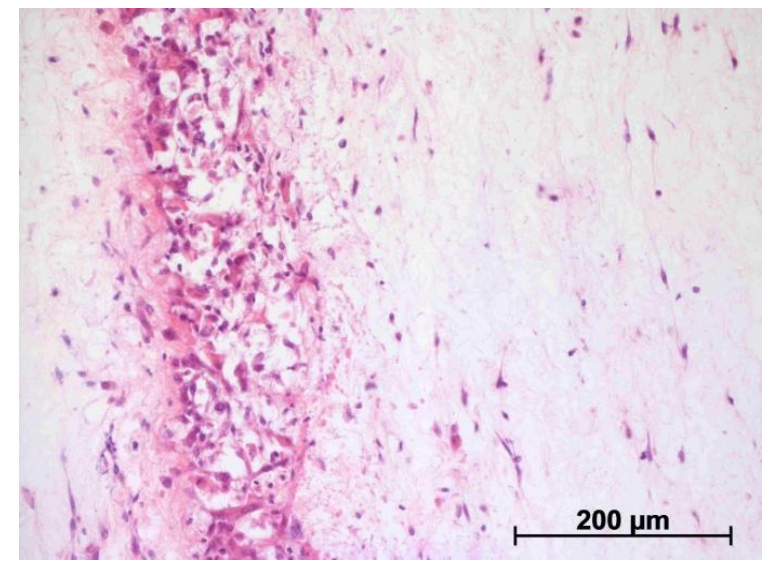

Abbildung 24: Patient 4; H.E.-Färbung; 20-fache Vergrößerung 4A: Patient 4A; 4B: Patient 4B

\section{Patient 5:}

Die Übersichtsaufnahme der Proben von Patient 5 zeigte in der Probe A (Abb. 25, 5A) eine Dreifach-Schichtung. Partiell war die mittlere zellreiche Schicht dieser Probe aufgrund der 
histologischen Bearbeitung ausgerissen. Die Probe B (Abb. 25, 5B) hingegen ließ eine Doppelschichtung vermuten. Eine der beiden Schichten war sehr deutlich abgebildet mit einem relativ homogenen Zellverteilungsmuster, die andere Lage enthielt zentral Zellakkumulationen, welche zusätzlich ausgerissen erschienen. Die Bestimmung der Gewebedicke wurde im schmalsten Anteil des Präparates gemessen. Für Probe A war ein Wert von 1744,19 $\mu$ m (Abb. 25, 5A) zu verzeichnen, für Probe B von 1798,77 $\mu$ m (Abb. 25, 5B).

5A.)

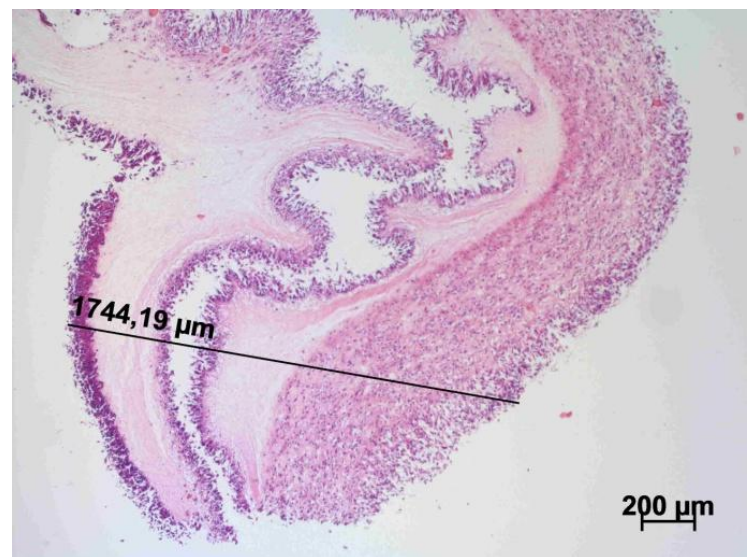

5B.)

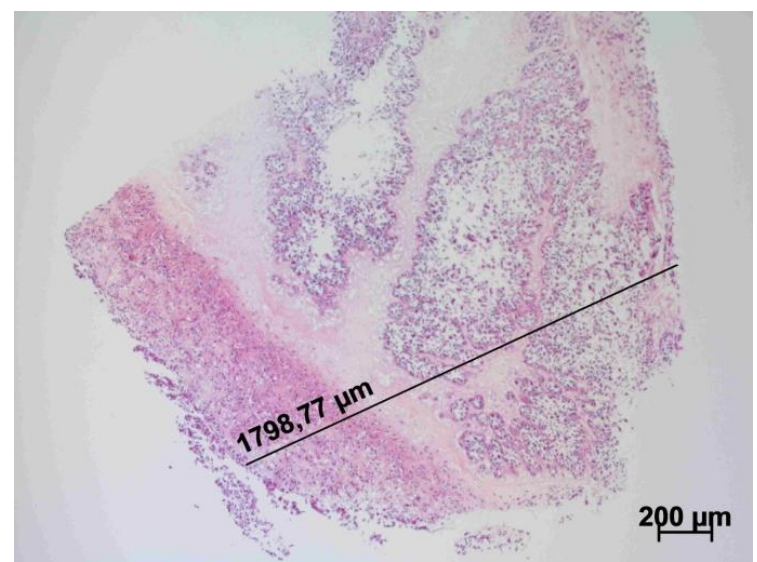

Abbildung 25: Patient 5; H.E.-Färbung; 5-fache Vergrößerung

5A: Patient 5A, mit Längenbestimmung; 5B: Patient 5B, mit Längenbestimmung

Die Zell-Kollagen-Verteilung war in beiden Proben in jeweils einer Lage homogen - in Abbildung 26, 5A rechtsseitig und in Abbildung 26, 5B linksseitig. Die anderen Schichten zeigten entweder stark zellreiche oder stark kollagenreiche Areale.

5A.)

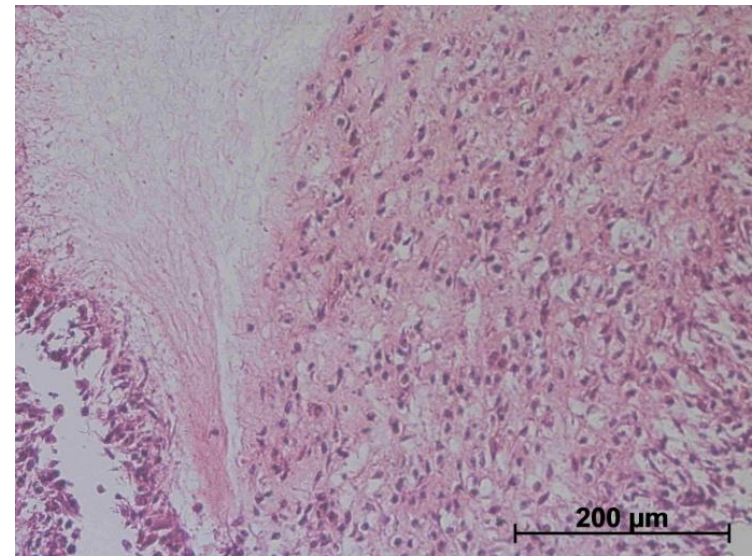

5B.)

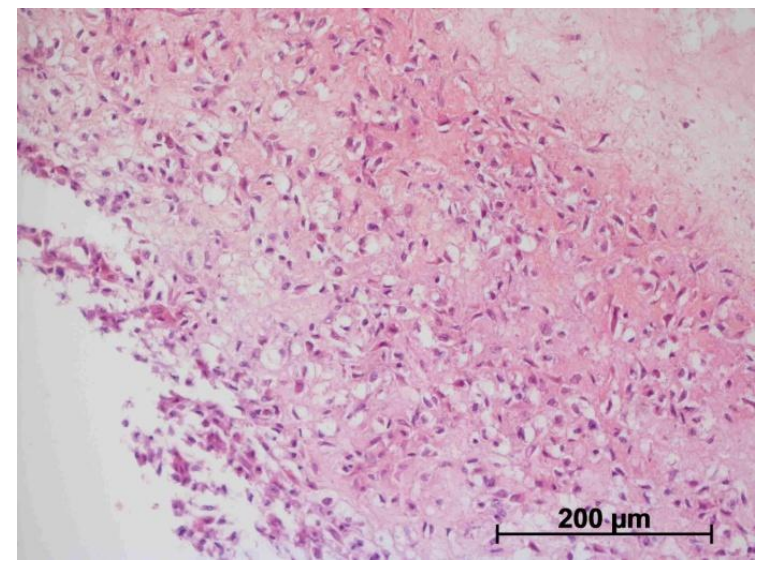

Abbildung 26: Patient 5; H.E.-Färbung; 20-fache Vergrößerung 5A: Patient 5A; 5B: Patient 5B

Alle Gewebedicken aus den Hauptversuchen sind in Tabelle 7 aufgelistet. Es wurde die durchschnittliche Dicke der hergestellten Bindegewebe-Konstrukte ermittelt. Sie lag bei $1704,73 \mu \mathrm{m}$, also bei ungefähr $1,7 \mathrm{~mm}$. 
Tabelle 7: Berechnung der Durchschnittsdicke

\begin{tabular}{|l|l|l|}
\hline Patient & Präparat A & Präparat B \\
\hline $\mathbf{1}$ & $1587,71 \mu \mathrm{m}$ & $1875,68 \mu \mathrm{m}$ \\
\hline $\mathbf{2}$ & $1510,72 \mu \mathrm{m}$ & $1926,14 \mu \mathrm{m}$ \\
\hline $\mathbf{3}$ & $1719,88 \mu \mathrm{m}$ & $1969,73 \mu \mathrm{m}$ \\
\hline $\mathbf{4}$ & $1320,30 \mu \mathrm{m}$ & $1603,19 \mu \mathrm{m}$ \\
\hline $\mathbf{5}$ & $1744,19 \mu \mathrm{m}$ & $1798,77 \mu \mathrm{m}$ \\
\hline Durchschnittsdicke & \multicolumn{2}{|c|}{$\mathbf{1 7 0 4 , 7 3} \boldsymbol{\mu m}$} \\
\hline
\end{tabular}

[A+B: Die hergestellten Präparate von Patient 1-5 in Doppelbestimmung]

Zusammenfassend zeigten die Ergebnisse der H.E.-Färbung der Hauptversuche eine durchschnittliche Gewebedicke von ca. 1,7 mm (Tab. 7). Das gezüchtete Bindegewebe-Konstrukt war dabei überwiegend kompakt und mehrschichtig. Eine gewisse Variabilität war hinsichtlich der Fibroblasten-Anordnung festzustellen: homogene bis partiell akkumulierte Fibroblastenanordnung. Die Kollagenfasern der Extrazellulärmatrix liefen überwiegend geflechtartig.

\subsection{Apoptose-Rate}

Die Apoptose-Rate innerhalb der Bindegewebeproben wurde mittels der TUNELFärbetechnik untersucht.

Exemplarisch wurde je ein mikroskopisches Bild aller 10 Gewebeproben in einer 20-fachen Vergrößerung unten abgebildet. Analysiert wurde bei der Bewertung das gesamte Präparat und nicht nur dieser Ausschnitt. Die TUNEL-Färbung wurde dabei der H.E.-Färbung des jeweiligen Präparats gegenübergestellt, um die Apoptose-Rate zu ermitteln.

\section{Patient 1:}

Die Abbildung 27 zeigt die Patientenproben 1A und 1B in der TUNEL-Färbung. Die Apoptose-Rate lag bei den Proben des ersten Patienten bei ungefähr einem Viertel der Zellen (Abb. 27, 1A und 1B). Die Probe A zeigte arealsweise auch etwas höhere Zahlen von Zelluntergängen (Abb. 27, 1A). Diese waren allerdings auf wenige Randgebiete beschränkt. 
1A.)

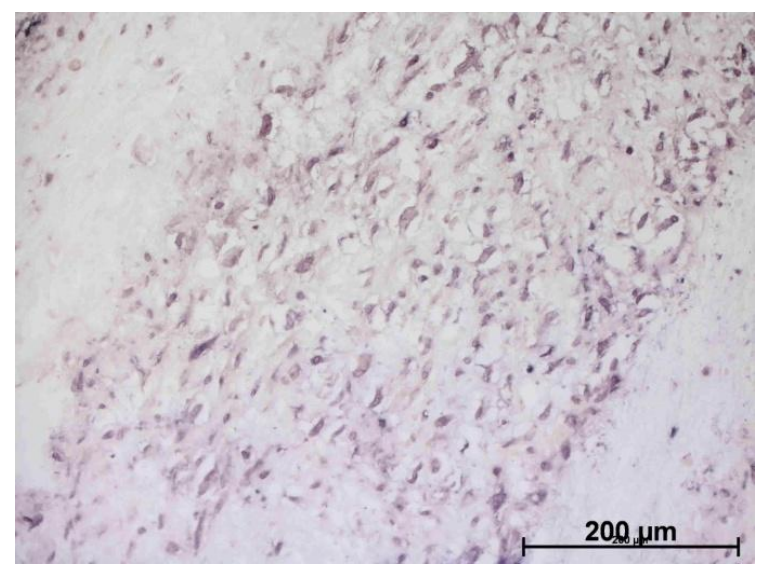

1B.)

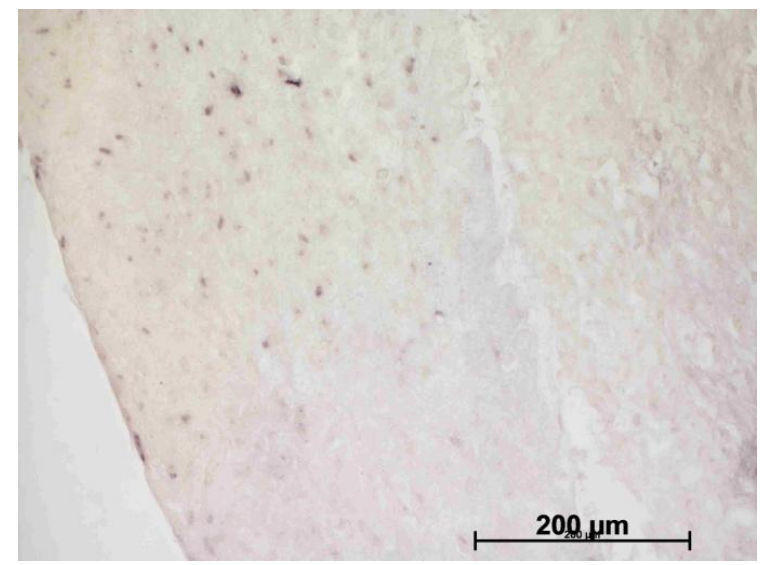

Abbildung 27: Patient 1; TUNEL-Färbung; 20-fache Vergrößerung

1A: Patient 1A; 1B: Patient 1B

\section{Patient 2:}

Die Apoptose-Rate des zweiten Patienten lag, in Relation zu der sichtbaren Zellmenge in der H.E.-Färbung, bei ca. der Hälfte der Zellen (Abb. 28, 1A). Bei der zweiten Patientenprobe (Abb. 28, 1B) hingegen waren über 3/4 der Gesamtzellen apoptotisch. Der überwiegende Anteil der Fibroblasten-Zellkerne war dunkel markiert. Für Probe B war somit ein überproportionaler Zelltod zu verzeichnen.

2A.)

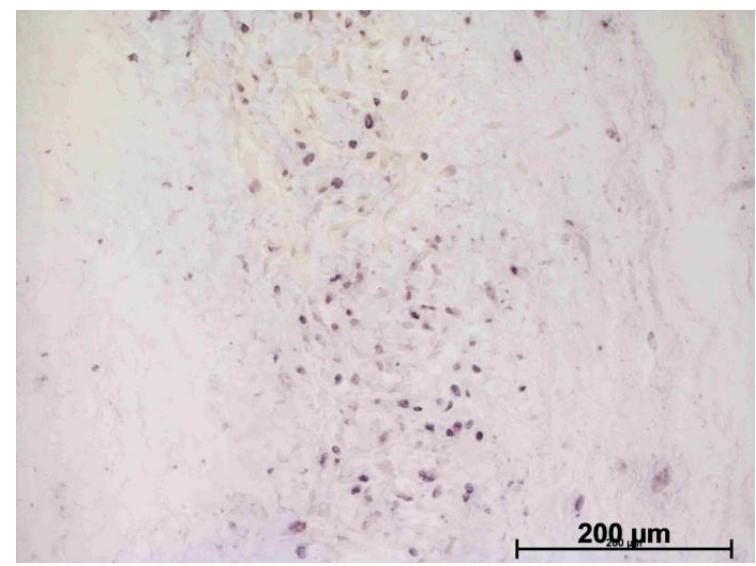

2B.)

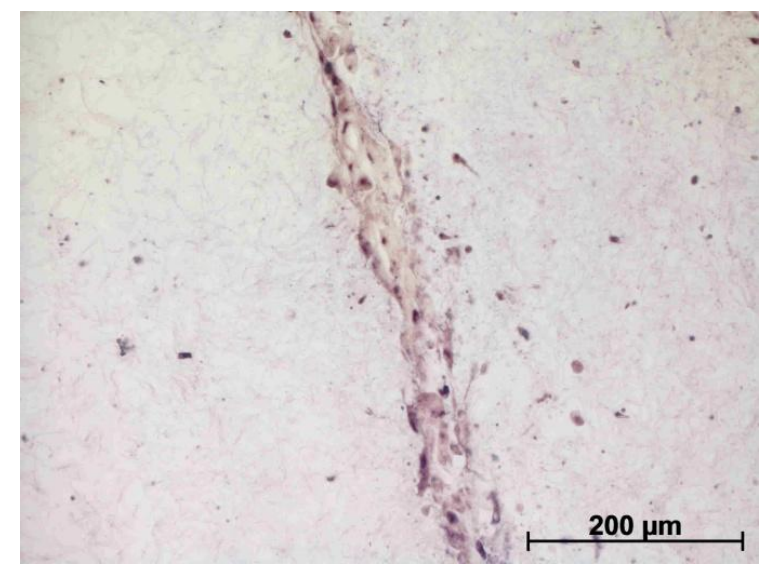

Abbildung 28: Patient 2; TUNEL-Färbung; 20-fache Vergrößerung 2A: Patient 2A; 2B: Patient 2B

\section{Patient 3:}

Der Apoptose-Grad in beiden Bindegewebsproben des dritten Patienten war niedrig und lag bei unter einem Viertel der Gesamtzellen (Abb. 29, 3A und 3B). Selbst die zellreicheren Areale zeigten keine vermehrten Zelluntergänge. 
3A.)

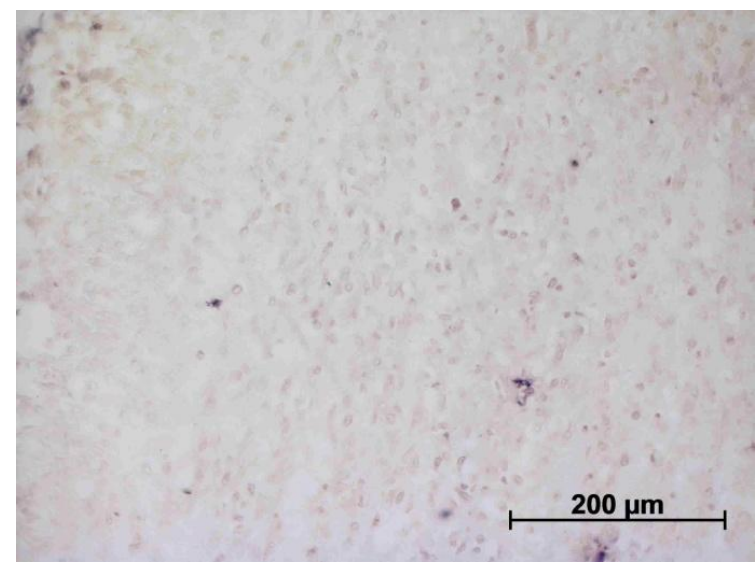

3B.)

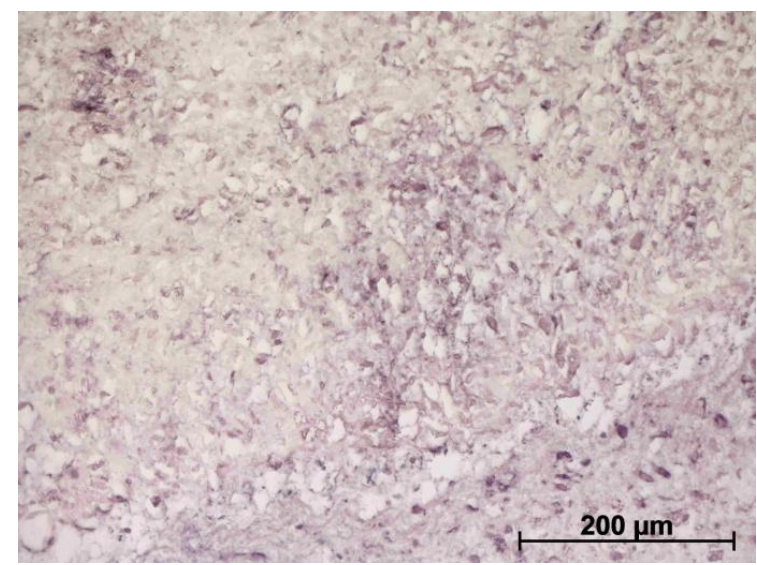

Abbildung 29:Patient 3; TUNEL-Färbung; 20-fache Vergrößerung

3A: Patient 3A; 3B: Patient 3B

\section{Patient 4:}

Abbildung 30 4A und 4B zeigt die beiden Proben des vierten Patienten. Das Ausmaß der dunkel angefärbten, apoptotischen Fibroblasten betrug annährend ein Viertel der Zellen. Zellreiche Areale zeigen mehr dunkel angefärbte Zellkerne als zellarme Gebiete. In Relation zur Zellzahl allerdings eine insgesamt niedrige Apoptose-Rate.

4A.)

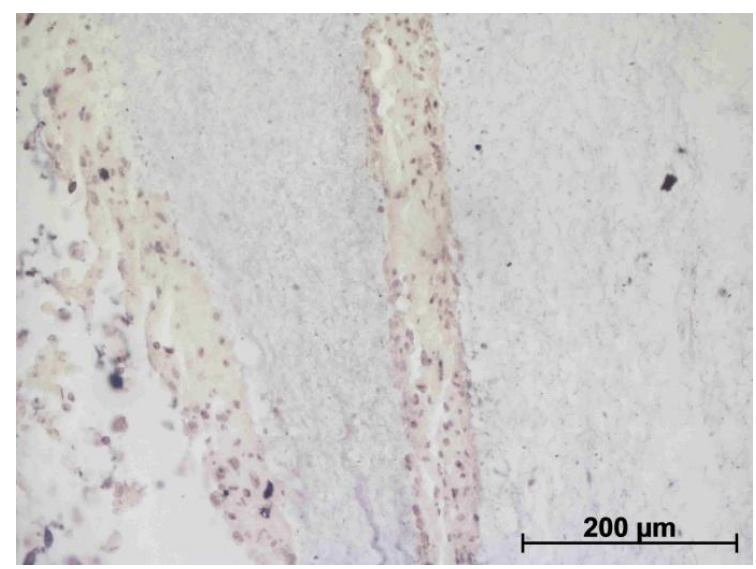

4B.)

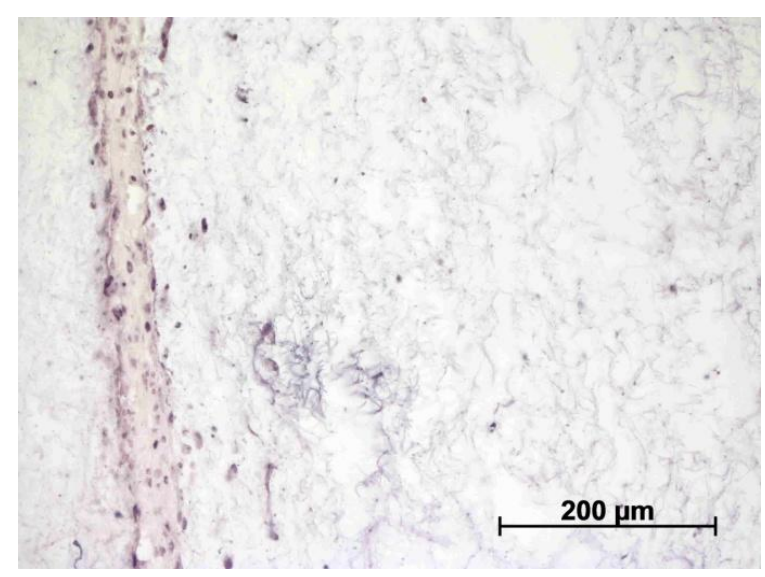

Abbildung 30: Patient 4; TUNEL-Färbung; 20-fache Vergrößerung

4A: Patient 4A; 4B: Patient 4B

\section{Patient 5:}

In beiden Proben von Patient 5 waren keine überschießenden apoptotischen Vorgänge zu sehen (Abb. 31, 5A und 5B). Die Zelluntergangsrate lag sowohl in Probe A als auch in Probe B bei ungefähr einem Viertel der Gesamtzellzahl. 
5A.)

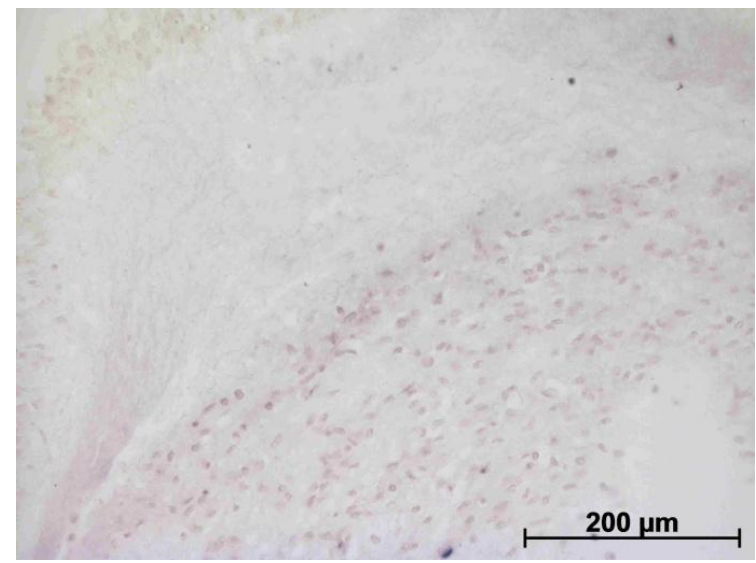

Abbildung 31: Patient 5; TUNEL-Färbung; 20-fache Vergrößerung
5B.)

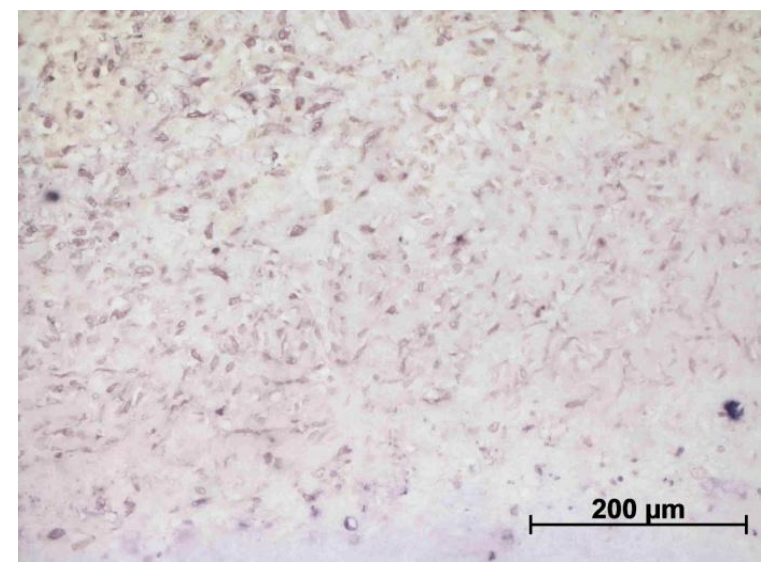
5A: Patient 5A; 5B: Patient 5B

Die Gesamtbetrachtung der Bindegewebsproben in der TUNEL-Färbung zeigte in acht von zehn Fällen einen Zelluntergang von bis zu einem Viertel der Gesamtzellen. Bei einer Probe lag die Apoptose-Rate bei ungefähr der Hälfte der Zellen und bei einer weiteren Probe bei über 3/4 der Fibroblasten. Somit zeigte insgesamt ein Großteil der Gewebe-Konstrukte keinen Nachweis von überschießender Apoptose. Es konnte geschlussfolgert werden, dass die Konstrukte überwiegend vital waren. 


\subsection{Kollagen-Eigensynthese}

Die unten dargestellten mikroskopischen Aufnahmen wurden mit einer 10-fachen Vergrößerung aufgenommen und sollen exemplarisch für die jeweiligen Patientenproben das Ausmaß der Kollagen-Eigensynthese demonstrieren.

\section{Patient 1:}

In beiden Präparaten waren große Anteile mit dicht gepackten und dicken Kollagenfasern (rot) und wenige Bereiche mit dünneren und jungen Kollagenfasern (grün) sichtbar (Abb. 32, 1A und 1B). Innerhalb der stärker rötlich angefärbten Anteile lagen netzartig dünne, grün angefärbte Kollagenfasern. Dabei machte der grüne Anteil schätzungsweise ca. 1/3 und der rote Anteil ca. 2/3 des Gesamtkollagens aus. Die zellreichen Areale der Gewebe-Konstrukt zeigten mehr rot angefärbte Fasern.

1A.)

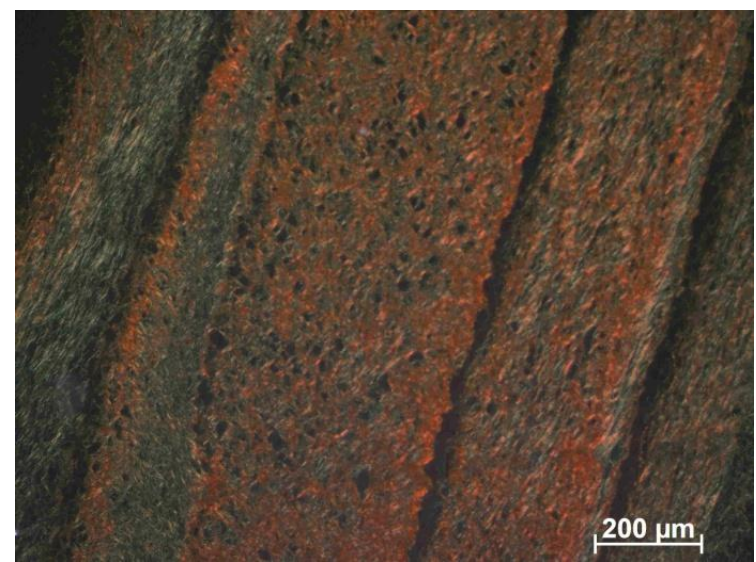

1B.)

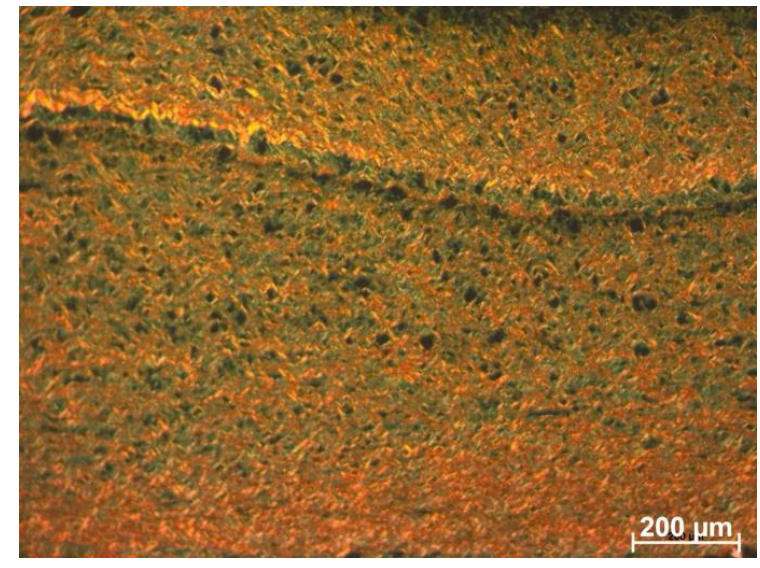

Abbildung 32: Patient 1; Sirius-Rot-Färbung; 10-fache Vergrößerung 1A: Patient 1A; 1B: Patient 1B

\section{Patient 2:}

Die Sirius-Rot-Färbung zeigte in beiden Präparaten annähernd nur grüne Anteile (Abb. 33, 2A und 2B). Der Großteil der Kollagenfasern war somit von feiner Struktur und gebildet durch die autologen Fibroblasten. Die zellreichen Bindegewebsareale zeigten in schmalen Übergangszonen zu den zellarmen Gebieten auch dickere kollagene Fasern (rot).

Wie bereits in den anderen Färbungen deutlich wurde, sah man auch eine schichtweise Anordnung der Gewebelagen in der Sirius-Rot-Färbung. Die jeweiligen Lagen waren nur mit dünnen (grünen) Kollagenfasern verbunden. 
2A.)

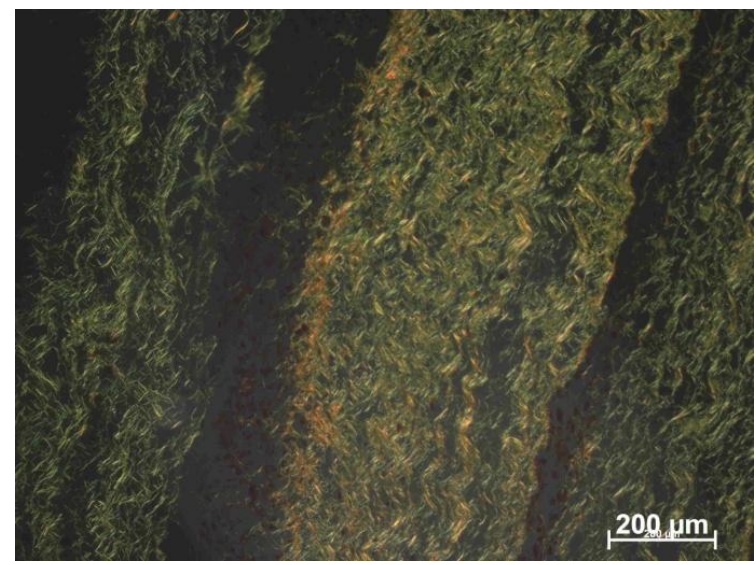

2B.)

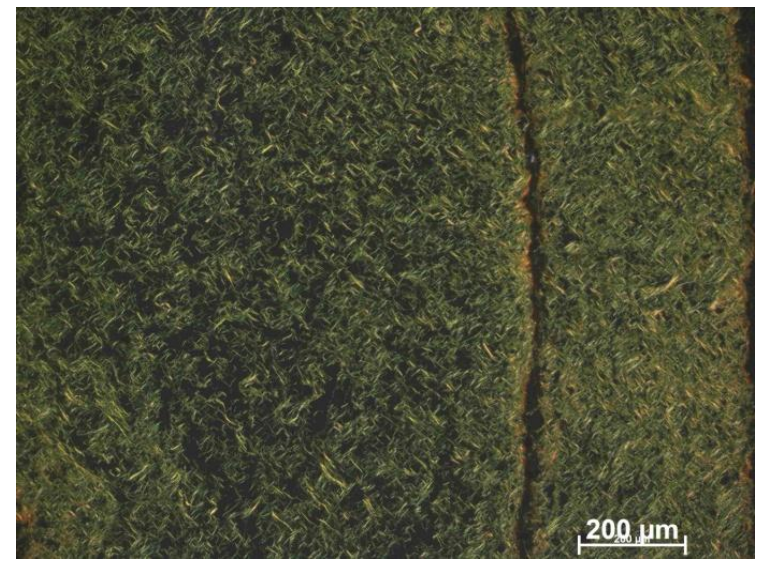

Abbildung 33: Patient 2; Sirius-Rot-Färbung; 10-fache Vergrößerung 2A: Patient 2A; 2B: Patient 2B

\section{Patient 3:}

Die Abbildung 34 zeigt beide Gewebeproben von Patient 3. In Präparat 3A waren Anteile mit vielen dünnen, grün angefärbten Kollagenfasern zu sehen, aber auch Gebiete mit überwiegend dicken (roten) Fasern (Abb. 34, 3A). Präparat B (Abb. 34, 3B) imponierte mit vielen dicken Fasern, innerhalb derer sich viele dünne Fasern verzweigten. Stark Zell-assoziierte Gewebeareale zeigten einen höheren Anteil dicht gepackter Kollagenfasern. Die Schichtung war auch hier in beiden Präparaten sichtbar und zeigte über feine Fasern Verstrebungen zur nächsten Schicht.

3A.)

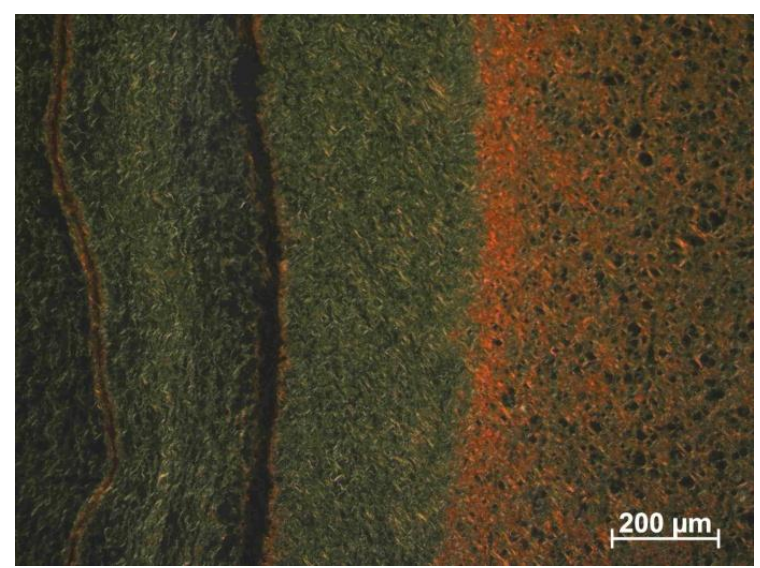

3B.)

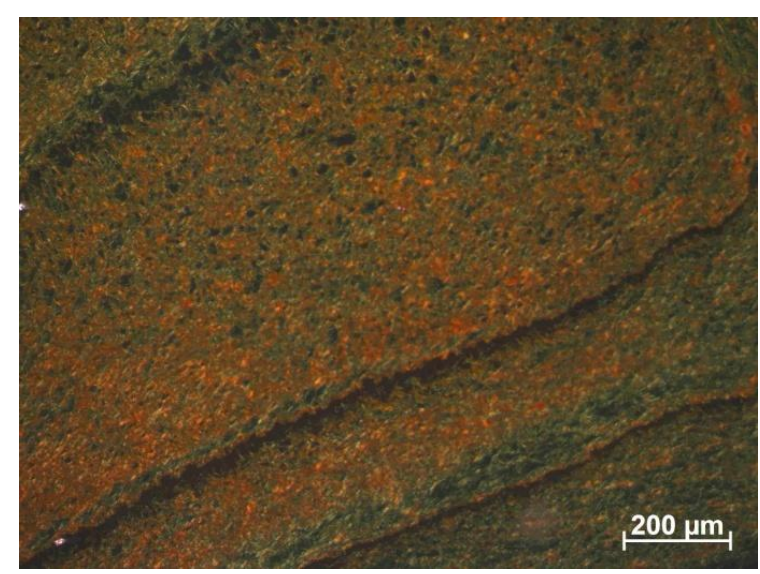

Abbildung 34: Patient 3; Sirius-Rot-Färbung; 10-fache Vergrößerung 3A: Patient 3A; 3B: Patient 3B

\section{Patient 4:}

Die Sirius-Rot-Färbung unter dem Kreuzpolarisationsfilter zeigte in beiden Proben des Patienten 4 überwiegend grünlich erscheinende feine Kollagenfasern (Abb. 35, 4A und 4B).

Die zellreichen Bindegewebsareale zeigten in schmalen Übergangszonen zu den zellarmen 
Gebieten auch dickere kollagene Fasern (rot). Die Schichtung war, wie in der H.E.- und TUNEL-Färbung, auch hier deutlich erkennbar.

4A.)

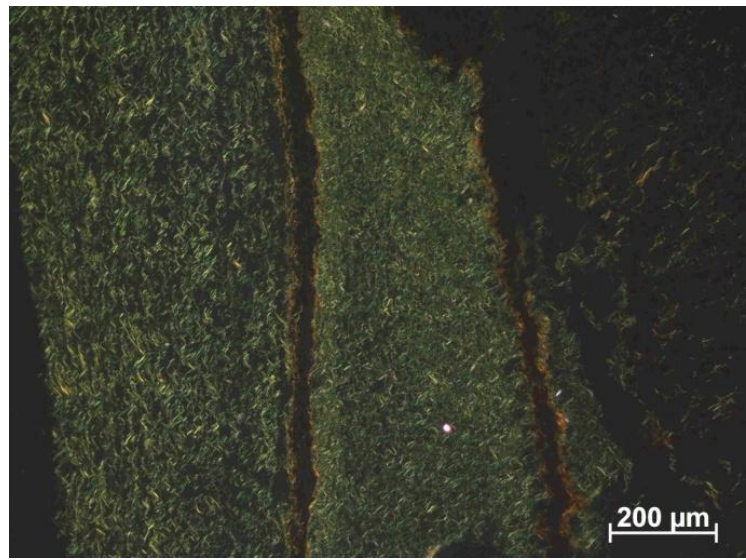

4B.)

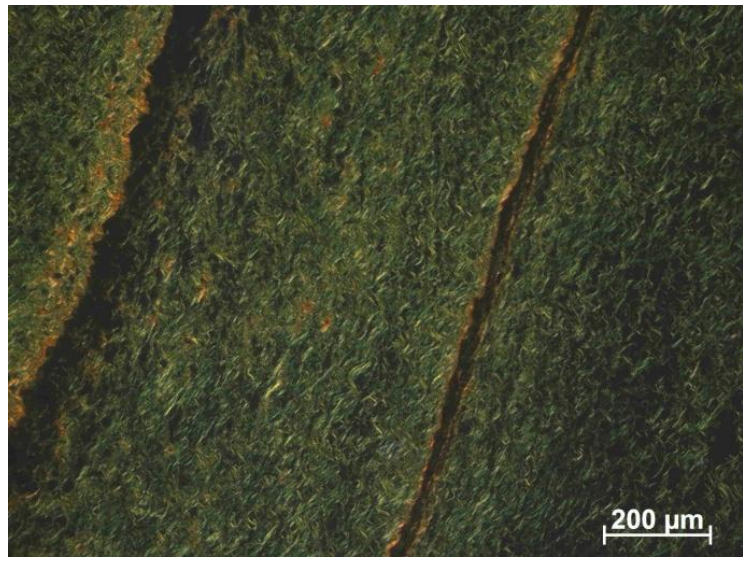

Abbildung 35: Patient 4; Sirius-Rot-Färbung; 10-fache Vergrößerung 4A: Patient 4A; 4B: Patient 4B

\section{Patient 5:}

Die Darstellung des kollagenen Netzwerkes zeigte in der Probe A (Abb. 36, 5A) für die zellärmeren Areale eine dominierend grünliche Anfärbung, für die zellreichen Bereiche eine gemischte, rot-grüne Anfärbung. Die Anfärbung der Probe B (Abb. 36, 5B) war relativ homogen in der Verteilung der rot und grün erscheinenden Kollagenfasern. Dabei überwog im oberen Teil des Präparatbildes leicht der rote Anteil, im unteren Teil des Bildes der grüne Anteil.

5A.)

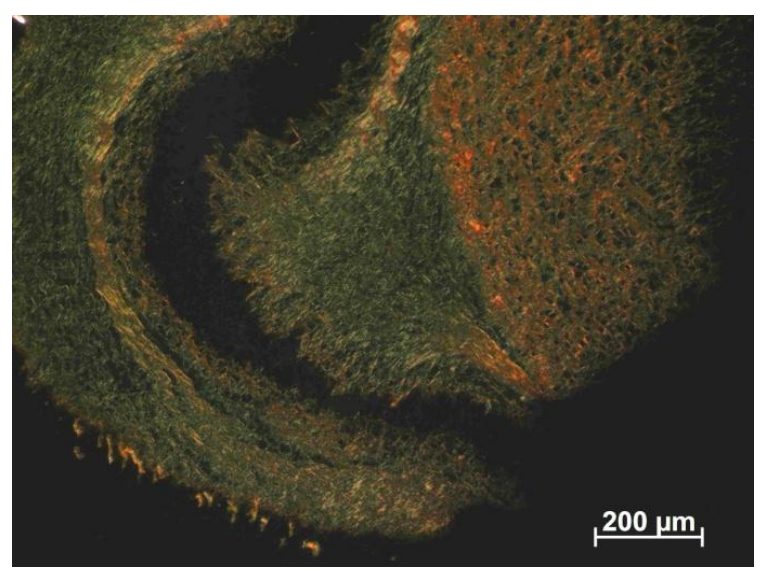

5B.)

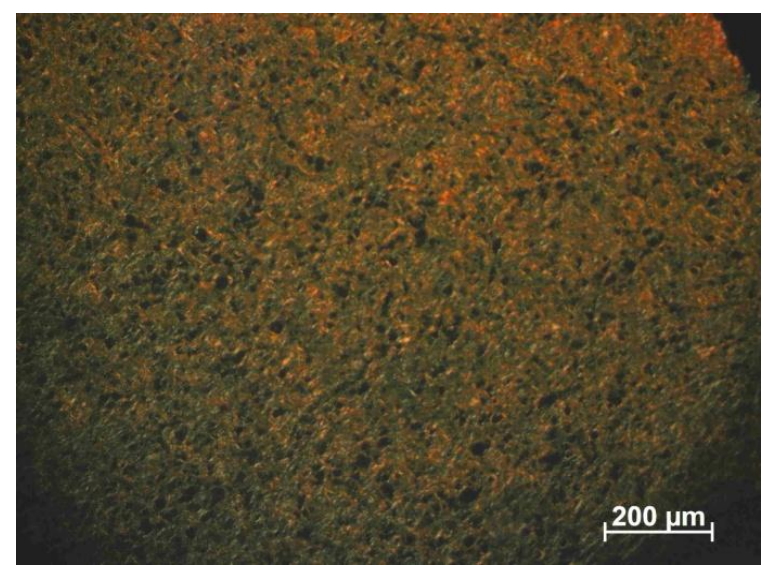

Abbildung 36: Patient 5; Sirius-Rot-Färbung; 10-fache Vergrößerung 5A: Patient 5A; 5B: Patient 5B

Die Beurteilung der Kollagen-Eigensynthese zeigte in vier von sechs Fällen eine mäßige und in den weiteren sechs Proben eine besonders stark ausgeprägte autologe Kollagenbildung. Insgesamt konnte in allen Fällen eine Kollagen-Eigensynthese nachgewiesen werden. 


\subsection{Zusammenfassung der Ergebnisse}

Nach Betrachtung der anfänglich angegebenen Kriterien mit den aufgeführten Methoden konnten folgende Ergebnisse ermittelt werden (Tab. 8).

Tabelle 8: Zusammenfassung der Ergebnisse

\begin{tabular}{|l|l|l|l|}
\hline Nr. & Kriterien & Methoden & Ergebnisse \\
\hline $\mathbf{1}$ & Gewebegröße/-fläche & $\begin{array}{l}\text { makroskopisch, direkte Län- } \\
\text { genmessung mit einem Lineal }\end{array}$ & $\mathbf{1 , 6 9 \mathbf { ~ c m } ^ { 2 }}$ \\
\hline $\mathbf{2}$ & Gewebedicke & $\begin{array}{l}\text { mikroskopisch mit der H.E.- } \\
\text { Färbung, computerunterstützt }\end{array}$ & $\mathbf{1 , 7} \mathbf{~ m m}$ \\
\hline $\mathbf{3}$ & $\begin{array}{l}\text { Homogenität der Zell- } \\
\text { Kollagen-Verteilung } \\
\text { (mit Fibroblasten-Dichte } \\
\text { und -Morphologie) }\end{array}$ & $\begin{array}{l}\text { mikroskopisch mit der H.E.- } \\
\text { Färbung }\end{array}$ & $\begin{array}{l}\text { homogene bis inhomo- } \\
\text { gene Zell-Kollagen- } \\
\text { Verteilung }\end{array}$ \\
\hline $\mathbf{4}$ & $\begin{array}{l}\text { Apoptose-Rate } \\
\text { mikroskopisch mit der TUNEL- } \\
\text { Färbung }\end{array}$ & $\begin{array}{l}\text { überwiegend vital } \\
\text { Rot-Färbung unter einem } \\
\text { Kreuzpolarisationsfilter }\end{array}$ & $\begin{array}{l}\text { Kollagen-Eigensynthese } \\
\text { in allen Fällen vorhan- } \\
\text { den }\end{array}$ \\
\hline $\mathbf{5}$ & Kollagen-Eigensynthese & &
\end{tabular}

Zusammenfassend lässt sich feststellen, dass ein durchschnittlich 1,69 $\mathrm{cm}^{2}$ großes, $1,7 \mathrm{~mm}$ dickes und überwiegend vitales Bindegewebe-Konstrukt hergestellt werden konnte. In allen Fällen wurde eine Kollagen-Eigensynthese nachgewiesen. Es lag eine Variabilität in der ZellKollagen-Verteilung in dem Sinne vor, dass Fibroblasten innerhalb des Kollagen-Netzwerks homogen bis partiell akkumuliert angeordnet waren. 


\section{Diskussion}

Ziel dieser Arbeit war die Etablierung einer standardisierten und einfach umzusetzenden Methode zur Bindegewebsherstellung im Rahmen eines Tissue-Engineering-Modells. Der Erfolg sollte anhand Größe, Dicke, Vitalität und Kollagen-Eigensynthese des hergestellten GewebeKonstrukts evaluiert werden.

Mit Hilfe von Vorversuchen wurden bestimmte Parameter wie die Zellkonzentration der ZellKollagen-Suspension und eine Mehrfachapplikation der Suspension sowie die Verwendung von Ascorbinsäure-haltigem 3D-Zellkulturmedium definiert. Innerhalb von insgesamt 4-6 Wochen konnte in den Hauptversuchen ein moderat großes, dickes und vitales Bindegewebe mit Kollagen-Eigensynthese hergestellt werden. Die Methode erwies sich als labortechnisch einfach und standardisierbar. Bei der vorliegenden Arbeit handelt es sich um eine Erstbeschreibung einer solchen Methode zur Bindegewebsherstellung. Das beliebte subepitheliale Bindegewebstransplantat aus dem Gaumen als Goldstandard in der Parodontal-Chirurgie soll damit zukünftig abgelöst werden.

Obwohl mit dieser Technik überwiegend erfolgreich gearbeitet werden konnte, sind weitere Versuche notwendig, um das angegebene Protokoll zu optimieren. Dies soll im Folgenden einzeln diskutiert werden.

\subsection{Diskussion des Versuchsaufbaus und der Methode}

\section{Gewebegröße/-fläche:}

Die Gewebegröße lag im Durchschnitt bei 1,69 $\mathrm{cm}^{2}$ und war somit deutlich höher als die zuvor postulierten $1 \mathrm{~cm}^{2}$. Aus der vorliegenden Literatur konnten diesbezüglich auch keine tiefergehenden Informationen gewonnen werden. Es kann allerdings ein Vergleich mit Bindegewebstransplanteten aus dem Gaumen vorgenommen werden. Zur Weichgewebsaugmentation und Rezessionsdeckung verwenden die Arbeitsgruppe SILVA et al. ein Transplantat von $1,34 \mathrm{~cm}$ x $0,7 \mathrm{~cm}$, also $0,94 \mathrm{~cm}^{2}$, und MÜLLER et al. $1,1 \mathrm{~cm}$ x $0,5 \mathrm{~cm}$, also $0,55 \mathrm{~cm}^{2}$ (Müller et al. 1998; Silva et al. 2010). Das im Tissue-Engineering-Verfahren hergestellte Bindegewebs-Konstrukt war größer. Dementsprechend sind bezogen auf die Größe keine Veränderungen zwingend vorzunehmen. 


\section{Gewebedicke}

Die Gewebedicke der hergestellten Bindegewebskondensate aus den oben beschriebenen Versuchen betrug im Durchschnitt ca. 1,7 mm.

Zum Zwecke der ausreichenden Sauerstoff- und Nährstoffversorgung der Fibroblasten in dem Bindegewebskonstrukt muss maximal diese Durchschnittsdistanz von 1,7 mm durch Diffusion überwunden werden. In der Literatur wird für nicht-prävaskularisiertes Gewebe eine Limitation ab einer Diffusionsstrecke von über $2 \mathrm{~mm}$ beschrieben (Griffith et al. 2005). Sauerstoff kann Diffusionsstrecken von über $9 \mathrm{~mm}$ überwinden, es ist daher eher die Nährstoffversorgung, welche größere Distanzen nicht bewältigen kann (Griffith et al. 2005). Aus diesem Grund besteht für die beschriebenen Versuchsergebnisse keine Begrenzung hinsichtlich der Sauerstoff- und Nährstoffzufuhr. Für nachfolgende Versuche müssen diese Begrenzungen beachtet werden.

Auch hier kann entsprechend dem zukünftig geplanten Indikationsfeld, nämlich der Weichgewebsaugmentation, ein Vergleich zum Bindegewebstransplant aus dem Gaumen hergestellt werden. MÖRMANN et al. definierten unter diversen Transplantat-Dimensionen eine Dicke von 1-1,5 mm als optimal zur Rezessionsdeckung (Mörmann et al. 1980). Auch andere Arbeitsgruppen implantierten mit Erfolg subepitheliales Bindegewebe aus dem Gaumen mit einer durchschnittlichen Dicke von 1,5 mm (Müller et al. 1998; Silva et al. 2010). Die Gewebedicke der im Zuge dieser Arbeit hergestellten Gewebe-Konstrukte (ca. 1,7 mm) lag im Durchschnitt somit nur geringfügig höher. Sicherlich muss an dieser Stelle auch beachtet werden, dass das in vitro produzierte Gewebe-Konstrukt eine niedrigere Festigkeit und Kompaktheit aufweist als das subepitheliale Bindegewebe aus dem Gaumen. Eine klinische Untersuchung nach In-Vivo-Implantation des Transplantats wird mehr Erkenntnisse bringen.

\section{Homogenität der Zell-Kollagen-Verteilung}

Die überwiegende Anzahl der Gewebeproben aus den Hauptversuchen zeigte innerhalb der einzelnen Schichten ein inhomogenes Verteilungsmuster der Fibroblasten. Die Zellen waren nicht in vollständigem Maße gleichmäßig in die Extrazellulärmatrix eingebettet. Diese Heterogenität war in den einzelnen Konstrukten unterschiedlich stark ausgeprägt. Die Fibroblasten-Akkumulation am äußeren Rand der Matrix zeigte allerdings innerhalb der Schichten stets in die gleiche Richtung (vgl. hierzu Bilder in „Ergebnisse“).

Eine Wanderung von Zellen in die Peripherie einer 3D-Matrix im Zuge des 3D-TissueEnginnerings wurde in einer ähnlichen Form auch von anderen Arbeitskreisen beobachtet 
(Kim et al. 1998; McGuigan und Sefton 2007). Eine hohe Zelldichte in einem entsprechend großen Konstrukt führe dazu, dass sich die Zellen Richtung Medium orientieren (Kim et al. 1998).

Diese uneinheitliche Zellverteilung innerhalb der hergestellten Gewebe-Konstrukte ist eher untypisch für das postulierte Zielgewebe, das Bindegewebe. Eine polarisierte Zellanordnung ist beispielsweise typischer für Keratinozyten innerhalb der Epidermis. Diese heterogene Fibroblasten-Verteilung innerhalb der Konstrukte ist, wie zuvor beschrieben, ein bekanntes Problem des Tissue Engineerings. Hinsichtlich dessen muss die Verwendung des Begriffes „Bindegewebe" für die hergestellten Konstrukte unter Vorbehalt genutzt werden.

Es muss eingehend analysiert werden, weshalb die Zellen diese Tendenz aufwiesen. Dazu können zwei Hypothesen aufgestellt werden: 1. Die Zellen richten sich zum Medium aus (Kim et al. 1998; McGuigan und Sefton 2007), 2. Die Fibroblasten sinken wegen der Porengröße des kollagenen Netzwerks ab.

Liegt die Fibroblasten-Akkumulation an der Ausrichtung zum Nährmedium hin, könnte eventuell die Versorgung mit Nährmedium optimiert werden, um so die Fibroblasten auch an den basalen Pol des Gewebe-Konstrukts zu lenken. Zum einen kann die Teflon-Kammer modifiziert werden. Es können kleine Bohrungen in den Boden der Form vorgenommen werden. Die Gewebekammer kann auf vier Füße gestellt werden, sodass auch unter die Form Medium fließen kann. Eine hohe Viskosität der Zell-Kollagen-Suspension in Kombination mit sehr feinen Bohrungen müsste dabei ein Abfließen der Suspension verhindern können. Zum anderen kann das Gewebe-Konstrukt selbst verändert werden. Diverse Arbeitsgruppen aus dem Feld des Tissue Engineering haben Modelle entwickelt, mit welchen die Gewebe schon in vitro vaskularisiert werden. Bei diesen Verfahren werden neben Fibroblasten auch Endothelzellen eingesetzt, welche cokultiviert werden müssen (McGuigan und Sefton 2006; KunzSchughart et al. 2006; Eckermann et al. 2011). Diese Variante ist sicherlich überlegenswert, aber in der Durchführung auch deutlich aufwendiger. Es ist abzuwägen, ob für die spezielle Fragestellung das Nutzen-Aufwand-Verhältnis ausgeglichen wäre.

Liegt die inhomogene Fibroblasten-Akkumulation allerdings an der Porengröße des kollagenen Netzwerks, müssen andere Maßnahmen ergriffen werden. Die Herstellung der ZellKollagen-Suspension erfolgte auf Eis, damit es nicht vorzeitig kondensierte und eine bessere „Handlichkeit“ aufwies. Nach Abgabe in die Teflon-Kammer wurde es zudem noch für 15 Minuten unter der Werkbank zum Vorkondensieren belassen. Die Versteifung der Suspension durch Kollagen-Quervernetzung erfolgt im warmen Milieu des Brutschrankes dann relativ schnell. Die definitive Porengröße innerhalb des Netzwerkes wurde somit nicht direkt bei 
Applikation erreicht, wodurch die Fibroblasten die Zeit bekamen, sich innerhalb des Netzwerks unter Einfluss der Schwerkraft abzusenken. Wie bereits in der Einleitung dieser Arbeit beschrieben, ist die Porengröße ein entscheidender Faktor für den Erfolg eines solchen Versuchsaufbaus (Lee et al. 2008). Um diesem Problem entgegenzuwirken, können Ursachenabhängig Lösungsstrategien entwickelt werden. Der einfachste Weg wäre zunächst zu erproben, ob die direkte Gabe der frisch in die Teflon-Kammer überführten Suspension in einen Brutschrank zum Erfolg führt. Die Vorkondensation unter der Werkbank würde man in diesem Fall „überspringen“. Ist die definitive Porengröße dennoch zu weit für die verwendeten Zellen, kann das kollagene Netzwerk modifiziert werden. Neben der Erhöhung der KollagenKonzentration innerhalb der Suspension können mit Hilfe einiger beschriebener Maßnahmen die Querverstrebungen zwischen den Kollagenfasern verstärkt werden: Der Einsatz von UVoder radioaktiver Strahlung, Glutaraldehyd oder Formaldehyd und die Verwendung von Polyhydroxyethylmethacrylat (PHEMA) seien hier exemplarisch zur Induktion der Quervernetzung des Kollagens erwähnt (Barbani et al. 1995; Weadock et al. 1996). Aber auch die mechanische Kompression des Kollagens zur Dehydrierung kann die Materialeigenschaften beeinflussen (Ghezzi et al. 2011). Dabei ändern sich neben der Porengröße des Netzwerks auch die mechanischen Eigenschaften des Gewebes. Allerdings ändert sich dabei auch die Biodegradierbarkeit des Kollagens. Die Fibroblasten würden somit länger benötigen, das vorgegebene bovine Kollagen in Eigenkollagen umzuwandeln (Gorham et al. 1992).

Die hier aufgeführten Ergebnisse können aufgrund fehlender Vergleichsdaten nicht mit anderen Angaben verglichen werden.

Die mikroskopische Untersuchung der hergestellten Präparate wies die Ausbildung mehrerer Schichten innerhalb des Bindegewebs-Konstrukts auf. $\mathrm{Zu}$ sehen waren 2-5 Lagen. Die Sirius-Rot-Färbung zeigte unter dem Kreuzpolarisationsfilter feine Kollagenfasern, welche die Schichten untereinander verbanden. Die einzelnen Applikationsschritte der Zell-KollagenSuspension waren somit mehr oder weniger stark zu erkennen. Dies lässt vermuten, dass sich die einzelnen Zell-Kollagen-Suspensionen für die Zeit der Inkubation (6 Tage) nicht vollständig miteinander verbunden haben. Weder während der Versuche selbst noch bei der histologischen Aufbereitung der Bindegewebskondensate war eine mechanische Instabilität zwischen den Lagen erkennbar. Ein Verbund scheint somit vorhanden gewesen zu sein; zu der Festigkeit dieses Verbundes kann hier allerdings keine tiefergehende Aussage getroffen werden. Dies müsste in weiteren Untersuchungen, wie Reißversuchen, ermittelt werden. 
Diese herstellungsbedingte sichtbare Sichtung innerhalb des Gewebe-Konstrukts ist eher atypisch für das postulierte Ziel, die Herstellung von Bindegewebe.

Um dieses Bild der Schichtung weitestgehend zu vermeiden, können in Folgeversuchen Änderungen am Protokoll vorgenommen werden: Eine längere Inkubation im Brutschrank könnte dem Konstrukt mehr Zeit einräumen, sich fester zusammenzulagern. Eine andere Möglichkeit wäre, die Dimensionen der 3D-Teflon-Kammer auszuloten und sie umzugestalten. Die Wände der Kammer könnten höher gestaltet werden, sodass eine höhere Menge der ZellKollagen-Suspension abgegeben werden könnte. Auf diese Weise könnte es zum Zwecke einer postulierten Gewebsdicke von ca. $1 \mathrm{~mm}$ ausreichen, die Suspension lediglich ein Mal abzugeben. Diese Methode sollte anschließend mit kritischem Blick auf die möglicherweise erhöhte Apoptose-Rate beurteilt werden. Bei diesen Vorschlägen handelt es sich um Spekulationen, die es experimentell zu überprüfen gilt. Sie können keinen Literaturangaben gegenübergestellt werden, da keine entsprechenden Untersuchungsergebnisse vorliegen.

Der Faserverlauf des Kollagens innerhalb der Extrazellulärmatrix der Bindegewebsproben war in den meisten Fällen geflechtartig. Ist eine Ausrichtung des Faserverlaufs im Bindegewebs-Konstrukt mit den darin enthaltenen Fibroblasten gewünscht, kann dies mit einfachen Hilfsmitteln umgesetzt werden. Die Teflon-Form müsste so verändert werden, dass die bestehende quadratische Form in eine rechteckige überführt wird. Richtet man sich dabei nach PHILLIPS UND BROWN, kann ein Verhältnis von 1:3 der Außenkanten verwendet werden. Die Zellen und die kollagenen Fasern richten sich dann vor allem im zentralen Drittel des Gewebes entlang der Längsachse der Form aus. So könnte die in dem oralen Weichgewebe vorherrschende Faserrichtung imitiert werden, um so zukünftig eine eventuell bessere in vivo Adaptation des in vitro produzierten Materials zu erreichen (Phillips und Brown 2011).

\section{Apoptose-Rate}

Die Apoptose-Rate wurde im Versuch mit der TUNEL-Färbung ermittelt. Die Beurteilung der Vitalität auf diese Weise war ausreichend, um Tendenzen zu ermitteln. Jedoch reicht diese Methode nicht aus, um spezifische Aussagen treffen zu können.

Hilfreich wäre sicherlich eine Gegenfärbung der Zellkerne und eine anschließende computerunterstütze Auswertung des prozentualen Apoptose-Grades. Damit lässt sich anhand konkreter Zahlen die In-Vitro-Überlebensfähigkeit der gebildeten Bindegewebsstücke ermitteln. 
Grundsätzlich kann versucht werden, den Zelluntergang in solch einem Aufbau noch weiter zu reduzieren. Der Einsatz einer Microfluid-Kammer zeigte in anderen Forschungsarbeiten bereits Erfolge. Untersucht wurden hierbei Einflussparameter wie $\mathrm{pH}-\mathrm{Wert}, \mathrm{CO}_{2^{-}}$sowie $\mathrm{O}_{2^{-}}$ Partialdruck und die Glukose-Konzentration (Kim et al. 1998). Auch die oben beschriebene Perforation der Teflon-Kammer mit beidseitiger Medium-Umspülung des Gewebes könnte einen positiven Effekt auf die Vitalität des Gewebe-Konstrukts haben. Es sei an dieser Stelle jedoch zu erwähnen, dass in einem In-Vitro-Modell die Partialdrücke anders sind als im lebenden Organismus.

\section{Kollagen-Eigensynthese}

Zur orientierenden Ermittlung der Kollagen-Eigensynthese der Fibroblasten unter Zusatz von Ascorbinsäure wurde die Sirius-Rot-Färbung eingesetzt.

Untersuchungen diverser Kollagen-Typen, u.a. auch Kollagen-Typ I, in der Sirius-RotFärbung zeigten, dass dünne Kollagenfasern mit einem Durchmesser kleiner als 0,8 $\mu \mathrm{m}$ grün erschienen. Rot erscheinen allerdings nicht nur dicke Kollagenfasern mit einem Durchmesser von 1,6 - 2,4 $\mu \mathrm{m}$, sondern auch sehr dicht gepackte (und besser ausgerichtete) kollagene Fasern (Dayan et al. 1989). Die Sirius-Rot-Färbung ist zudem besonders spezifisch für sehr dünne kollagene Fasern (Rich und Whittaker 2005).

In Vorversuchen wurde der positive Effekt von Ascorbinsäure-haltigem Medium in der 3DGewebekultur, wie er bereits in der Literatur beschrieben wird, untersucht (Pinnell 1985; Tsutsumi et al. 2012). TSUTSUMI et al. haben spezifisch die Wirkung von Ascorbinsäure (Ascorbinsäure Magnesium-Salz, wie auch in der vorliegenden Arbeit) auf gingivale Fibroblasten untersucht (Tsutsumi et al. 2012). In der vorliegenden Arbeit wurde die gleiche Konzentration an Ascorbinsäure verwendet. Die zuvor genannte Arbeitsgruppe ermittelte einen zeitabhängigen Anstieg von Typ-I-Kollagen, welcher sich vor allem nach 48 Stunden als markant darstellte. Bei neutralem pH-Wert erwies sich zudem das Magnesium-Salz der Ascorbinsäure als stabiler als die reine Ascorbinsäure (Geesin et al. 1993).

In den Vorversuchen zeigten Gewebe-Konstrukte mit Ascorbinsäure-Zusatz im Medium deutlich höhere Anteile an grünen, also dünnen Fasern, als jene Konstrukte, die ohne Ascorbinsäure in Kultur waren. Im Vorversuch „Ascorbinsäure-Zusatz“ wurde das Protokoll zur Herstellung von Gewebe lediglich im Zusatz von Ascorbinsäure modifiziert. Dieser Unterschied in der Anfärbung in den Vorversuchen mit und ohne Ascorbinsäure wies darauf hin, dass Ascorbinsäure einen Effekt in der 3D-Zellkultur ausgeübt hat. Dieser Effekt legte die Vermu- 
tung nahe, dass neue, dünne Kollagenfasern produziert worden waren. Als Hauptproduzenten von kollagenen Fasern gelten die Fibroblasten. Diese benötigen für die Kollagen-Synthese Ascorbinsäure als Cofaktor (Pinnell 1985; Tsutsumi et al. 2012).

Das mechanische Grundgerüst für die Fibroblasten bestand aus bovinem Kollagen-Typ I. In der 3D-Zellkultur hatten die Fibroblasten die Fähigkeit das bestehende Kollagen zu degradieren. Auf der anderen Seite stellen die bestehenden Fibroblasten aus Primärkultur die einzigen Produzenten von de novo synthetisiertem Kollagen dar.

Nichtsdestotrotz muss unterstrichen werden, dass die Verwendung der Sirius-Rot-Färbung und die Interpretation der Färbeergebnisse lediglich eine Tendenz für die Wirkung von Ascorbinsäure auf die Kollagen-Eigensynthese darstellen sollte. Wie viele Anteile des in der Sirius-Rot-Färbung abgebildeten Kollagens tatsächlich von den primären humanen Fibroblasten gebildet worden sind und welche Anteile dicht gelagertes und degradiertes bovines Kollagen sind, muss in spezifischen Test untersucht werden. Eine Weiterführung des vorgestellten Tissue-Engineering-Modells sollte eine genaue Untersuchung der Extrazellulärmatrix und des Kollagens beinhalten.

Die genaue Messung der Kollagen-Eigensynthese kann über andere Methoden erfolgen wie beispielsweise:

\section{ELISA (Enzyme Linked Immmunosorbent Assay)}

2. real time RT-PCR (reverse Transkriptase Polymerase-Kettenreaktion).

In den Hauptversuchen war der Anteil an grünen Kollagenfasern unterschiedlich groß. Diese Unterschiede in der vermuteten Menge der Kollagen-Eigensynthese in den Hauptversuchen gilt es kritisch zu beäugen. Die Gewebe-Biopsien wurden aus überwiegend entzündungsfreien Verhältnissen gewonnen. Eine leichte Inflammation der oralen Mukosa lag teilweise vor. Diese kann Grund für eine reduzierte Kollagenbildung der Fibroblasten in den Hauptversuchen sein. Zukünftige Versuchsdurchführungen sollten mit Zellen aus vollständig entzündungsfreiem Gewebe erfolgen. In den Hauptversuchen lässt die Assoziation dicker Kollagenfasern in Fibroblasten-Nähe folgende Spekulationen zu, die es in Folgeversuchen zu untersuchen gilt. Es stellt sich die Frage, ob diese dicken Fasern bereits Produkte der Fibroblasten sind oder doch noch verbliebenes bovines Kollagen aus der Zell-Kollagen-Suspension. Die Polymerisation des Eigen-Kollagens der Fibroblasten zu dicken Kollagenfasern bzw. das gerichtete Aneinanderlagern der Kollagenfasern zu Bündeln erfordern laut Literatur eine Inkubationszeit von einigen Wochen (Rich und Whittaker 2005). Die Klärung dieser Frage kann nur anhand 
spezifischer Behandlung und anschließender Untersuchung der Extrazellulärmatrix nach Zellauswaschung erfolgen. Diese weiterführende Analyse würde konkrete Erkenntnisse liefern. Es kann ermittelt werden, wie lange das gezüchtete Bindegewebe-Konstrukt im Brutschrank inkubiert werden muss, um ggf. völlig frei von Fremdmaterial zu sein. Die Fibroblasten können mit ihren zelleigenen Kollagenasen das eingesetzte bovine Kollagen degradieren; parallel dazu synthetisieren sie eigenständig eine neue Extrazellulärmatrix. Wird auf diese Weise das bovine Kollagen vollständig abgebaut und gegen selbst-synthetisiertes ersetzt, kann in einem späteren In-Vivo-Modell das Bindegewebs-Konstrukt als vollständig „autolog“ eingesetzt werden. Es darf dabei nicht außer Acht gelassen werden, dass das für die Bindegewebsherstellung verwendete Kollagen vom Typ I bovinen Ursprung ist. Hierbei handelt es sich also um ein xenogenes Material, dessen Qualitätskontrolle schwierig ist, z.B. können eventuelle Krankheitserreger nicht mit 100 \%iger Sicherheit ausgeschlossen werden. Es ist also abzuwägen, ob ein synthetisch hergestelltes Oligopeptid als Gerüst für die 3D-Zellkultur nicht zu bevorzugen ist (Gelain et al. 2006). Bovines Kollagen hat sich allerdings bislang als sehr biokompatibel erwiesen und induziert sehr gute Zellanhaftungsraten (Neunzehn et al. 2012). Der Erfolg eines neu angewendeten Materials/einer Materialkombination ist dann anhand unterschiedlicher Parameter zu beurteilen. Dazu gehören die Ermittlung der Zytotoxizität des Materials, die Ausprägung der Zelladhäsion, die Anregung der Proliferationsrate, die Aufrechterhaltung des Phänotyps und die Untersuchung mechanischer Attribute wie Rigidität, Zugfestigkeit, Elastizität und Komprimierbarkeit.

\section{Varianz unter den Geweben}

Die hergestellten Gewebe-Konstrukte zeigten in der Auswertung der Ergebnisse eine Varianz. Auf die möglichen Hintergründe soll im Folgenden eingegangen werden.

Jeweils zwei Konstrukte wurden mit den Primärzellen desselben Patienten hergestellt (in den Ergebnissen markiert in „,A“ und „B“). Die Versuche erfolgten nämlich in Doppelbestimmung.

Insgesamt wurden primäre Fibroblasten von fünf verschiedenen Patienten gewonnen und für die 3D-Zellkultur verwendet. Deshalb ergeben sich Individuum-abhängige Zellproliferationsund Zellsynthese-Raten. Die Proben wurden, wie in „Material und Methoden“ beschrieben, aus überwiegend entzündungsfreien Verhältnissen entnommen. Das bedeutet, dass nicht alle Proben aus einer völlig gesunden oralen Situation entnommen wurden. Leicht 
inflammatorisches Gewebe zeigt eine Varianz in der Zellkommunikation und -regulation, die es zu beachten gilt.

Zudem wurden die Patienten für die Probenentnahme nicht auf ein explizites Alter oder eine Geschlechtsgruppe hin ausgewählt. Somit ergibt sich eine Alters- und GeschlechterDiskrepanz unter den entnommenen Proben.

Das manuelle und von Menschenhand durchgeführte Versuchsprotokoll erzeugt trotz der Einhaltung größter Sorgfalt minimale Unterschiede in der Herstellung der Gewebe-Konstrukte. Auch minimale Unterschiede in der Handhabung der Proben während der Zellkulturen, können Auswirkung auf die Fibroblasten haben.

Zusammenfassend führen folgende Punkte zu einer Varianz der Zellproliferations- und Synthese-Raten und somit auch unter den Konstrukten:

1. Individuum-abhängige Unterschiede

2. Entzündungsfreie bis leicht inflammatorische Verhältnisse

3. Alter der Patienten

4. Geschlecht der Patienten

5. manuelle Durchführung des Versuchsprotokolls

Unterschiede in der Darstellung müssen auch darauf bezogen werden, dass die histologische Untersuchung der produzierten Konstrukte sich als äußert schwierig darstellte. Es mussten vier unterschiedliche Protokolle zur Einbettung der Präparate gegeneinander getestet werden. Probleme wie Schrumpfungen und Brüchigkeit der Gewebe-Konstrukte innerhalb des Paraffin-Blocks mussten überwunden werden. Die in dieser Arbeit verwendete Methode erwies sich als die beste von den getesteten vier Protokollen. Nichtsdestotrotz könnte es ein überlegeneres Protokoll für solche Konstrukte geben. Eine andere Schwierigkeit stellte die exakte Positionierung des Konstruktes auf der gewählten Schnittkante dar. Das Präparat sollte unter dem Mikroskop die gesamte Höhe des Gewebe-Konstruktes darstellen.

Bei der Literaturrecherche zur histologischen Aufbereitung von Tissue-EngineeringKonstrukten mit primären Fibroblasten und Kollagen-Gel gab es zwei Probleme. Das verwendete Protokoll wurde nicht eingehend dargelegt oder bei dem untersuchten Gewebe handelte es sich um ein Anderes, von den mechanischen Eigenschaften und verwendeten Ingredienzen variierend. 


\subsection{Vergleich zu anderen Modellen}

Im zahnmedizinischen Bereich wurden erste Versuchsaufbauten zum 3D-Tissue Engineering von Bindegewebe vorgestellt und klinisch erprobt.

Die Durchsicht der Literatur ergab Beschreibungen diverser Modelle, die sich untereinander im Wesentlichen in der Auswahl des Grundgerüstes und der Zellen sowie deren Kombination unterschieden. Exemplarisch sollen an dieser Stelle vielversprechende Modelle vorgestellt werden. Bei den im Folgenden beschriebenen Studien handelt es sich ausschließlich um humane Modelle. MCGUIRE und NUNN untersuchten den Einsatz eines Polygalactin-Netzes mit eingebetteten Fibroblasten aus der Vorhaut von Neugeborenen (Zelllinie). Neben der allgemeinen Weichgewebsaugmentation wurde hier mit Erfolg eine Vermehrung speziell der befestigten Gingiva erzielt. Dieses Polygalactin-Modell wurde zudem gegen ein Bindegewebstransplantat aus dem Gaumen erprobt. Im klinischen Vergleich mit einem Eigentransplantat wurde es als gleichwertig eingestuft (McGuire und Nunn 2005). Die Arbeitsgruppe JHAVERI et al. stellten wenige Jahre später eine andere Methode vor. Anstelle des künstlichen Polygalactin-Netzes als mechanisches Grundgerüst zur Zelladhäsion, verwendeten sie eine allogene azelluläre Dermis aus einer Spenderbank. Vor Insertion im Patientenmund wurde sie mit autologen Fibroblasten gesät. Die Zellen wurden dafür zu einem früheren Zeitpunkt gewonnen und in Zellkultur vermehrt. Auch bei diesem Modell zeigte sich im klinischen Vergleich mit einem subepithelialen Bindegewebs-Transplantat Gleichwertigkeit im Erfolg der Defektdeckung (Jhaveri et al. 2010). Beide Modelle verzeichneten erste Erfolge von in vitro gezüchteten Weichgewebstransplantaten. Es zeigte sich annähernd eine Ebenbürtigkeit zum Eigentransplantat, bislang der Goldstandart zur Weichgewebsvermehrung in der Parodonotologie. Die beiden Forschungsgruppen DOMINIAK et al. und KÖSEOĞLU et al. entwickelten wiederum 3D-Tissue-Engineering-Modelle mit Kollagen als mechanisches Gerüst. Die Kollagen-Matrix wurde mit autologen primären Fibroblasten bestückt, für ca. 48 Stunden inkubiert und dann zur Rezessionsdeckung in Probanden eingesetzt. Die Effizienz dieses Transplantats wurde gegenüber einer azellulären Kollagen-Matrix untersucht und erwies sich als überlegen (Dominiak et al. 2010, 2012; Köseoğlu et al. 2013).

Keines der oben erwähnten Modelle arbeitete allerdings mit rein autologem Material. Auch der Umbau und Abbau des eingesetzten Fremdmaterials wurden nicht weitergehend untersucht. Soll ein Gewebe aus dem Verfahren des Tissue Engineering in den Menschen implantiert werden, ist es erstrebenswert, ein überwiegend autologes Material herzustellen. Etwaige Immunreaktionen und Unverträglichkeiten können auf diese Weise minimiert werden (Preynat-Seauve et al. 2009). 
Das im Zuge dieser Arbeit vorgestellte Modell verwendet primäre humane Fibroblasten aus einer Biopsie und bovines Kollagen-Gel. Das Protokoll wurde während der 3D-Zellkultur so angepasst, dass die Fibroblasten in diesem Rahmen bereits einen Umsatz von selbst produzierter Extrazellulärmatrix aufwiesen. Das bovine Kollagen wurde partiell abgebaut und durch eine neu gebildete, junge Extrazellulärmatrix ersetzt. In welchem Ausmaß das Fremdkollagen in Eigenkollagen umgebaut worden ist, wurde in diesem Projekt nicht im Detail untersucht.

\subsection{Ausblick}

Die oben exemplarisch genannten Modelle wurden verwendet, um gingivale Rezessionen zu decken und Weichgewebe im Allgemeinen zu augmentieren. Sie wurden im Falle der Rezessionsdeckung vorwiegend mit der oralchirurgischen Technik des koronalen Verschiebelappens oder der Tunnel-Technik kombiniert. Nach Feinjustierung des in dieser Arbeit beschriebenen Protokolls wird ein ähnliches Einsatzgebiet für das hergestellte Bindegewebskondensat anvisiert. Gelingt dies erfolgreich, kann ein weiterer Schritt geplant werden: die Keratinisierung bzw. Epithelialisierung des Bindegewebes und damit die Erweiterung des Einsatzspektrums.

Zur konkreten Umsetzung einer keratinisierten Mukosa müssen aus der Biopsie neben Fibroblasten auch Keratinozyten gewonnen und kultiviert werden. Die Fibroblasten-Kultivierung wird nach der oben erläuterten Methode durchgeführt. Keratinozyten hingegen bedürfen eines anderen Zellkulturmediums und einer spezifischen Zellkultivierung auf 3T3-Zellen (Feederlayer). Dabei handelt es sich um Fibroblasten, welche mit Röntgenstrahlung in ihrem Wachstum gehemmt werden (Moharamzadeh et al. 2008; MacNeil et al. 2011; Llames et al. 2013). Auch die Möglichkeit des epithelialen, nicht-keratinisierten Besatzes eines oralen MukosaModells auf der Grundlage eines Glykosaminoglykan-Chitosan-Gerüstes fand bereits eine erfolgreiche Umsetzung (Kinikoglu et al. 2009). In beiden Ansätzen ist hervorzuheben, dass sich die Kultivierung von Keratinozyten und Epithelzellen deutlich aufwendiger und techniksensitiver gestaltet. Zudem geschieht die eigenständige Epithelialisierung von Bindegewebe im Mundraum so zügig, dass sich die Frage stellt, ob ein derartiger Mehraufwand zur Epithelialisierung von Gewebe gerechtfertigt ist.

Das vorgestellte Tissue-Engineering-Modell hat, so wie es vorliegt, zahlreiche Stärken. Dennoch hat es auch einige Schwächen. Im Folgenden werden diese Attribute bündig zusammengefasst. Zu den Stärken dieser Arbeit gehören die Tatsachen, dass innerhalb von 4-6 Wochen aus einer kleinen Biopsie ein moderat großes, dickes und überwiegend vitales Gewebe- 
Konstrukt mit einfachen labortechnischen Mitteln im 3D-Tissue-Engineering-Verfahren hergestellt werden konnte.

Das eingesetzte bovine Kollagen vom Typ I konnte den ersten Untersuchungen nach partiell durch die Fibroblasten degradiert und dank des Ascorbinsäure-Zusatz im 3D-ZellkulturMedium partiell durch eine autologe Extrazellulärmatrix ersetzt werden. Kritikpunkte wie der unvollständige Abbau des bovinen Kollagens, eine inhomogene Zell-Kollagen-Verteilung sowie die Ausbildung von Schichtungen müssen zukünftig noch weiter untersucht werden.

Sie seien als Schwachpunkte dieser Methode genannt. Das vorherrschende Modell kann sicherlich unter Berücksichtigung oben genannter Änderungsvorschläge weiter verbessert werden.

Das primär definierte Ziel dieser Arbeit war die Herstellung von Bindegewebe. An dieser Stelle sei erneut ausdrücklich darauf hingewiesen, dass die Verwendung der Bezeichnung „Bindegewebe“ für die Produkte aus diesem Tissue-Engineering-Modell nicht ganz korrekt ist und kritisch bewertet werden sollte.

Nach Optimierung des Versuchsprotokolls sollte eine erste klinische Erprobung des Materials in einem Tiermodell erfolgen. Eine gute Handhabung des hergestellten Gewebe-Konstrukts sowie eine erfolgreiche Defektversorgung ohne außerordentliche Abwehrreaktionen sollten dabei untersucht werden. Zeigt das hergestellte Bindegewebe im Tierexperiment keine negativen Auffälligkeiten, kann dieses Tissue-Engineering-Modell ggf. auch am Menschen Einsatz finden.

Schlussfolgernd lässt sich folgendes zusammenfassen: Mit dem vorgestellten 3D-TissueEngineering-Modell lässt sich ein Bindegewebe-ähnliches Konstrukt labortechnisch einfach und reproduzierbar herstellen. Diese Arbeit bietet eine solide Grundlage für das Tissue Engineering von Bindegewebe-Konstrukten. Das in der Parodontal-Chirurgie favorisiert verwendete subepitheliale Bindegewebstransplantat zu Rezessionsdeckung und Weichgewebsaugmentation soll damit zukünftig abgelöst werden. Der Erfolg eines solchen Verfahrens würde dem Patienten bei den zuvor genannten Eingriffen das Zweit-Operationsgebiet mit allen bekannten Nachteilen ersparen. Gleichzeitig könnten die gründlich untersuchten und anerkannten operativen Techniken zur Weichgewebsvermehrung weiter angewandt werden. 


\section{Zusammenfassung}

Target: Tissue engineering is a biomedical technology, which has the potential to both repair damaged tissue and to create tissues de novo. There are various different complex methods, which have been previously described to generate a three-dimensional (3D) tissue; however, no simple methods have been presented yet for the reconstruction of connective tissue for dental treatment. The aim of this present study was to establish a simple method to fabricate connective tissue within a 3D tissue engineering model. Parameters including size, thickness, vitality and self-production of collagen fibers were assessed in order to characterize the fabricated tissues.

Materials and Methods: Gingival probes obtained from 5 different patients were extracted during parodontal surgery and brought into cell culture. The cultivated fibroblasts were firstly used to produce cell-collagen suspensions $\left(2.5 \times 10^{6}\right.$ cells $\left./ \mathrm{ml}\right)$, which was then transferred into our novel designed Teflon chambers. This procedure was repeated three times for three consecutive days, while the cell suspensions were cultivated in the presence of ascorbic acid rich medium. The tissues were incubated for a total of six days and thereafter subsequently fixed and removed out of the chambers for histological assessment. The tissues were assessed for: 1) thickness and homogeneity of fibroblast arrangement in the collagen scaffold via Hematoxylin and Eosin (H.E.) staining; 2) cellular apoptosis with Transferase Uridyl Nick End Labeling (TUNEL) assay; and 3) self-fabricated collagen with Sirius Red staining.

Results: All 5 tissue probes demonstrated a compact and multilayered connective tissue reproduction. An average tissue thickness of $1.7 \mathrm{~mm}$ and surface area of $1.69 \mathrm{~cm}^{2}$ were obtained respectively. Histological analyses showed a dense collagen scaffold with varying fibroblast arrangements (homogenous up to accumulated to one tissue terminal), while the vast of the tissue was vital. In all tissues a self-production of collagen was detected.

Conclusion: With our novel 3D tissue engineering model connective tissue reconstructions can be fabricated easily and reproducible. This method offers a good foundation for following researchers with the aim to produce connective tissue for in vivo usage for dental applications. 


\section{Anhang}

\subsection{Veröffentlichung}

Diese Arbeit wurde am 10. Januar 2014 als Vortrag auf der 46. Jahrestagung der Arbeitsgemeinschaft für Grundlagenforschung in der DGZMK in Mainz unter dem folgenden Titel vorgestellt: H. Karatas, M. Hoch, M. Tiburcy, W. Zimmermann, D. Ziebolz: „Etablierung eines 3-dimensionalen Tissue-Engineering-Modells zur Bindegewebsherstellung“‘ 


\subsection{Abbildungsverzeichnis}

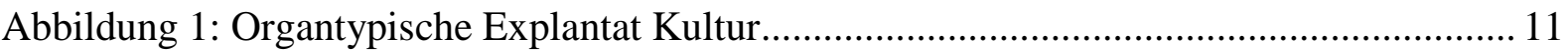

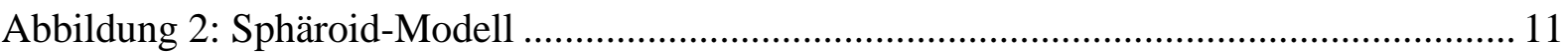

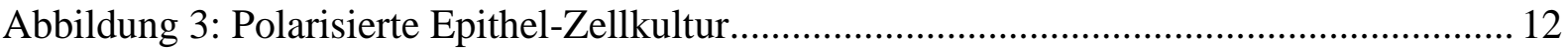

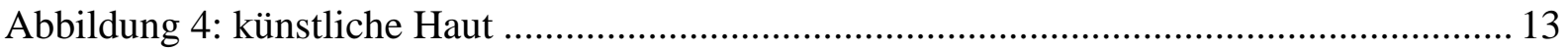

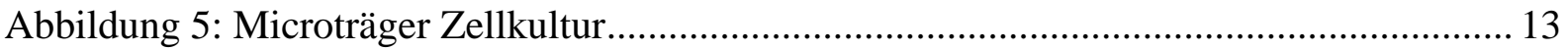

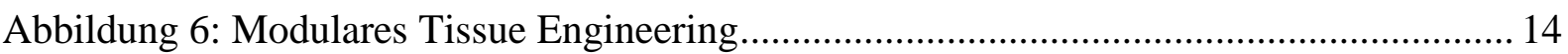

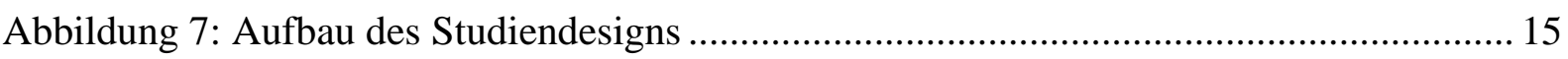

Abbildung 8: primare Fibroblasten in Zellkultur .............................................................. 17

Abbildung 9: Teflon-Kammer mit Einzeichnung der Kantenlängen ...................................... 19

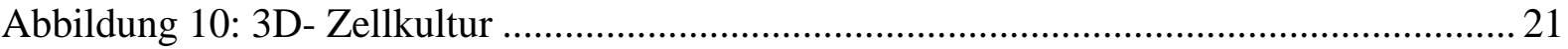

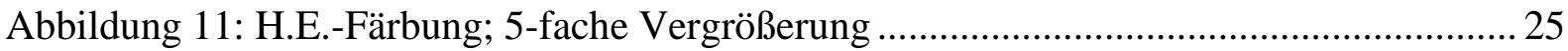

Abbildung 12: Bindegewebe in TUNEL-Färbung; 10-fache Vergrößerung ............................ 28

Abbildung 13: Sirius-Rot-Färbung unter Kreuzpolarisationsfilter; 10-fache Vergrößerung ... 31

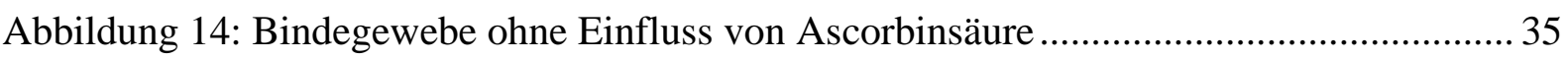

Abbildung 15: Bindegewebe mit Einfluss von Ascorbinsäure ............................................. 36

Abbildung 16: Bindegewebe nach 6 Tagen Kondensation ................................................... 39

Abbildung 17: Patient 1; H.E.-Färbung; 5-fache Vergrößerung ................................................ 40

Abbildung 18: Patient 1; H.E.-Färbung; 20-fache Vergrößerung ............................................ 41

Abbildung 19: Patient 2; H.E.-Färbung; 5-fache Vergrößerung ................................................ 41

Abbildung 20: Patient 2; H.E.-Färbung; 20-fache Vergrößerung ........................................... 42

Abbildung 21: Patient 3; H.E.-Färbung; 5-fache Vergrößerung ............................................ 43

Abbildung 22: Patient 3; H.E.-Färbung; 20-fache Vergrößerung .......................................... 43

Abbildung 23: Patient 4; H.E.-Färbung; 5-fache Vergrößerung ............................................. 44

Abbildung 24: Patient 4; H.E.-Färbung; 20-fache Vergrößerung ............................................. 44

Abbildung 25: Patient 5; H.E.-Färbung; 5-fache Vergrößerung ............................................ 45

Abbildung 26: Patient 5; H.E.-Färbung; 20-fache Vergrößerung ............................................. 45

Abbildung 27: Patient 1; TUNEL-Färbung; 20-fache Vergrößerung .................................... 47

Abbildung 28: Patient 2; TUNEL-Färbung; 20-fache Vergrößerung .................................... 47

Abbildung 29:Patient 3; TUNEL-Färbung; 20-fache Vergrößerung ..................................... 48

Abbildung 30: Patient 4; TUNEL-Färbung; 20-fache Vergrößerung ...................................... 48

Abbildung 31: Patient 5; TUNEL-Färbung; 20-fache Vergrößerung .................................... 49

Abbildung 32: Patient 1; Sirius-Rot-Färbung; 10-fache Vergrößerung ................................... 50

Abbildung 33: Patient 2; Sirius-Rot-Färbung; 10-fache Vergrößerung .................................. 51 
Abbildung 34: Patient 3; Sirius-Rot-Färbung; 10-fache Vergrößerung .................................. 51

Abbildung 35: Patient 4; Sirius-Rot-Färbung; 10-fache Vergrößerung .................................. 52

Abbildung 36: Patient 5; Sirius-Rot-Färbung; 10-fache Vergrößerung .................................. 52 


\subsection{Tabellenverzeichnis}

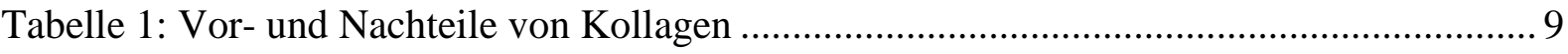

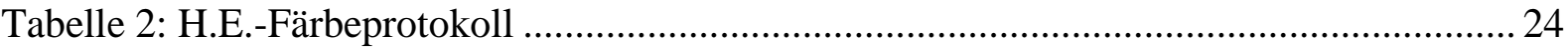

Tabelle 3: variierende Gewebe-Morphologie, 20-fache Vergrößerung, H.E.-Färbung ........... 26

Tabelle 4: unterschiedliche Apoptose-Raten; 10-fache Vergrößerung; TUNEL-Färbung ...... 29

Tabelle 5: Untersuchungskriterien und Methoden für die Hauptversuche ............................. 38

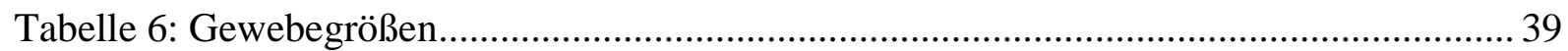

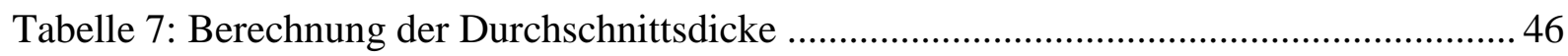

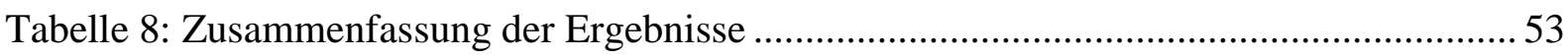




\subsection{Material-Liste}

\begin{tabular}{|c|c|c|c|}
\hline Material & $\begin{array}{l}\text { Zusätze } \\
\text { /Konzentration }\end{array}$ & Bestellnummer & Hersteller \\
\hline Agarose-Gel, NuSieve & $3: 1$ & 50090 & $\begin{array}{l}\text { Cambrex Bio Science } \\
\text { Rockland Inc. } \\
\text { Maine (USA) }\end{array}$ \\
\hline Alkohol & - & 642 & $\begin{array}{l}\text { Hausapotheke Uni- } \\
\text { Göttingen }\end{array}$ \\
\hline $\begin{array}{l}\text { Amphotericin B, } \\
100 \mathrm{ml}\end{array}$ & $250 \mu \mathrm{g} / \mathrm{mL}$ & P 06-01100 & $\begin{array}{l}\text { PAN-Biotech GmbH, } \\
\text { Aidenbach, } \\
\text { www.pan-biotech.de }\end{array}$ \\
\hline $\begin{array}{l}\text { Ascorbinsäure, L- } \\
\text { Ascorbic acid 2- } \\
\text { phosphate, } \\
\text { sesquimagnesium salt } \\
\text { hydrate }\end{array}$ & - & A $8960-5 \mathrm{G}$ & $\begin{array}{l}\text { SIGMA-ALDRICH } \\
\text { CHEMIE GmbH, } \\
\text { Steinheim, } \\
\text { www.sigmaaldrich.com }\end{array}$ \\
\hline $\begin{array}{l}\text { Bovine Collagen Type I, } \\
\text { Acid Soluble Collagen, } \\
100 \mathrm{ml}\end{array}$ & $7,25 \mathrm{mg} / \mathrm{ml}$ & CS 006 & $\begin{array}{l}\text { Collagen Solutions LLC, } \\
\text { San Jose (USA) } \\
\text { www.collagensolutions.co } \\
\mathrm{m} \\
\end{array}$ \\
\hline $\begin{array}{l}\text { Brutschrank, } \mathrm{CO}_{2}- \\
\text { Incubator } \mathrm{MCO}-17 \mathrm{~A}\end{array}$ & - & - & $\begin{array}{l}\text { Sanyo Electric Biomedical } \\
\text { Co.,Ltd.,Japan, } \\
\text { Nenndorf } \\
\text { www.sanyo-biomedical.de }\end{array}$ \\
\hline $\begin{array}{l}\text { BSA, bovines Serum } \\
\text { Albumin, Albumin } \\
\text { Fraktion V, bovine }\end{array}$ & - & 8076.2 & $\begin{array}{l}\text { Carl Roth GmbH + Co. } \\
\text { KG, } \\
\text { Karlsruhe, } \\
\text { www.carlroth.com }\end{array}$ \\
\hline Direktrot 80 & - & $365548-5 \mathrm{G}$ & $\begin{array}{l}\text { SIGMA-ALDRICH } \\
\text { CHEMIE GmbH, } \\
\text { Steinheim, } \\
\text { www.sigmaaldrich.com }\end{array}$ \\
\hline $\begin{array}{l}\text { DMEM + GlutaMAX, } \\
500 \mathrm{ml}\end{array}$ & $\begin{array}{l}4,5 \mathrm{~g} / \mathrm{L} \text { Glucose } \\
\text { Pyruvate }\end{array}$ & 31966-021 & $\begin{array}{l}\text { GIBCO } \\
\text { Invitrogen Corporation, } \\
\text { Karlsruhe, } \\
\text { www.invitrogen.com }\end{array}$ \\
\hline $\begin{array}{l}\text { DMEM, } \\
\text { Pulver }\end{array}$ & $\begin{array}{l}\text { (+) } 4500 \mathrm{mg} / \mathrm{l} \mathrm{Glu-} \\
\text { cose } \\
\text { (+) L-Glutamine } \\
\text { (+) Pyruvate } \\
\text { (-) NaHCO3 }\end{array}$ & $12800-116$ & $\begin{array}{l}\text { GIBCO } \\
\text { Invitrogen Corporation, } \\
\text { Karlsruhe, } \\
\text { www.invitrogen.com }\end{array}$ \\
\hline $\begin{array}{l}\text { DNase I recombinant, } \\
\text { grade I }\end{array}$ & 2 X 10.000 Units & 04536282001 & $\begin{array}{l}\text { Roche Diagnostics GmbH, } \\
\text { Mannheim, } \\
\text { www.roche-applied- } \\
\text { science.com }\end{array}$ \\
\hline $\begin{array}{l}\text { Einbettgerät, Leica EG } \\
1150 \mathrm{H}\end{array}$ & - & - & $\begin{array}{l}\text { Leica Biosystems Nussloch } \\
\text { GmbH, } \\
\text { Nussloch, } \\
\text { www.leicabiosystems.com }\end{array}$ \\
\hline $\begin{array}{l}\text { Einfriermedium, } \\
\text { Biofreeze }\end{array}$ & - & F 2270 & $\begin{array}{l}\text { Biochrom AG, } \\
\text { Berlin, } \\
\text { www.biochrom.de }\end{array}$ \\
\hline
\end{tabular}




\begin{tabular}{|c|c|c|c|}
\hline Eppendorf Pipetten & - & - & $\begin{array}{l}\text { Eppendorf AG, } \\
\text { Hamburg, } \\
\text { www.eppendorf.com }\end{array}$ \\
\hline Essigsäure & $100 \%$ & 7X009332 & $\begin{array}{l}\text { AppliChem GmbH } \\
\text { Darmstadt, } \\
\text { www.applichem.com }\end{array}$ \\
\hline $\begin{array}{l}\text { Falcon BD Röhrchen } \\
\text { 15ml }\end{array}$ & - & $35-2099$ & $\begin{array}{l}\text { Becton, Dickinson and Co., } \\
\text { New Jersey (USA), } \\
\text { www.bd.com }\end{array}$ \\
\hline $\begin{array}{l}\text { Falcon BD Röhrchen } \\
\text { 50ml }\end{array}$ & - & $35-2074$ & $\begin{array}{l}\text { Becton, Dickinson and Co., } \\
\text { New Jersey (USA), } \\
\text { www.bd.com }\end{array}$ \\
\hline Feuchtkammer & - & - & $\begin{array}{l}\text { Carl Roth GmbH + Co. } \\
\text { KG, } \\
\text { Karlsruhe, } \\
\text { www.carlroth.com }\end{array}$ \\
\hline $\begin{array}{l}\text { FKS (fetales Kälber } \\
\text { Serum), } \\
500 \mathrm{ml}\end{array}$ & - & S0115 & $\begin{array}{l}\text { Biochrom AG, } \\
\text { Berlin } \\
\text { www.biochrom.de }\end{array}$ \\
\hline Formalin & 4\%ig gepuffert & - & $\begin{array}{l}\text { CVH Chemie-Vertrieb } \\
\text { GmbH \& Co. KG, } \\
\text { Hannover, } \\
\text { www.cvh.de }\end{array}$ \\
\hline $\begin{array}{l}\text { Gentamycin, } \\
50 \mathrm{ml}\end{array}$ & - & A 2712 & $\begin{array}{l}\text { Biochrom AG, } \\
\text { Berlin, } \\
\text { www.biochrom.de }\end{array}$ \\
\hline Glasbehälter mit Deckel & - & $7045-06-035$ & $\begin{array}{l}\text { Neubert Glas GbR, } \\
\text { Geschwenda/Thür, } \\
\text { www.neubert-glas.de }\end{array}$ \\
\hline $\begin{array}{l}\text { H.E.-Färbeautomat, } \\
\text { Tissue Tek Film, Film } \\
\text { E2 }\end{array}$ & - & - & $\begin{array}{l}\text { Sakura Finetec USA, Inc. } \\
\text { Torrance (USA), } \\
\text { www.sakura-americas.com }\end{array}$ \\
\hline $\begin{array}{l}\text { Hämalaunlösung sauer } \\
\text { nach Mayer }\end{array}$ & - & T865.2 & $\begin{array}{l}\text { Carl Roth GmbH + Co. } \\
\text { KG, } \\
\text { Karlsruhe, } \\
\text { www.carlroth.com }\end{array}$ \\
\hline Kryoröhrchen & - & 377272 & $\begin{array}{l}\text { Nunc A/S, } \\
\text { Roskilde (Dänemark), } \\
\text { www.nuncbrand.com }\end{array}$ \\
\hline Kühlschrank & - & - & $\begin{array}{l}\text { Liebherr-International } \\
\text { Deutschland GmbH, } \\
\text { Biberach an der Riss, } \\
\text { www.liebherr.com }\end{array}$ \\
\hline Metallförmchen & - & LEIH3803084 & $\begin{array}{l}\text { Leica Biosystems Nussloch } \\
\text { GmbH, } \\
\text { Nussloch, } \\
\text { www.leicabiosystems.com }\end{array}$ \\
\hline $\mathbf{M g C l}_{2}$ & - & - & $\begin{array}{l}\text { Carl Roth GmbH + Co. } \\
\text { KG, } \\
\text { Karlsruhe, } \\
\text { www.carlroth.com }\end{array}$ \\
\hline $\begin{array}{l}\text { Microtom, Leica } \\
\text { RM2255 }\end{array}$ & - & - & $\begin{array}{l}\text { Leica Biosystems Nussloch } \\
\text { GmbH, } \\
\text { Nussloch, } \\
\text { www.leicabiosystems.com }\end{array}$ \\
\hline
\end{tabular}




\begin{tabular}{|c|c|c|c|}
\hline $\begin{array}{l}\text { Mikroskop, Axioscop } 2 \\
\text { plus mit Farb-Kamera } \\
\text { Axio Cam MRc5 }\end{array}$ & - & - & $\begin{array}{l}\text { Carl Zeiss GmbH, } \\
\text { Oberkochen, } \\
\text { www.zeiss.de }\end{array}$ \\
\hline $\begin{array}{l}\text { Mikroskop, Zeiss } \\
\text { Axiovert } 35\end{array}$ & - & 48725 & $\begin{array}{l}\text { Carl Zeiss GmbH, } \\
\text { Oberkochen, } \\
\text { www.zeiss.de }\end{array}$ \\
\hline $\begin{array}{l}\text { Mikrowelle, Sanyo Digi- } \\
\text { tal }\end{array}$ & - & - & $\begin{array}{l}\text { Sanyo Electric Co., } \\
\text { Osaka (Japan), } \\
\text { www.panasonic.net }\end{array}$ \\
\hline $\begin{array}{l}\text { Mr. Frosty, Freezing } \\
\text { Container }\end{array}$ & - & $5100-0001$ & $\begin{array}{l}\text { Thermo Fisher Scientific, } \\
\text { Langenselbold, } \\
\text { www.nalgenelabware.com }\end{array}$ \\
\hline Natriumcitrat & - & - & $\begin{array}{l}\text { Carl Roth GmbH + Co. } \\
\text { KG, } \\
\text { Karlsruhe, } \\
\text { www.carlroth.com }\end{array}$ \\
\hline Natriumhydroxid, 1N & $1 \mathrm{~N}$ & - & $\begin{array}{l}\text { Merck KGaA, } \\
\text { Darmstadt, } \\
\text { www.merck.de }\end{array}$ \\
\hline $\begin{array}{l}\text { NBT/BCIP Stock Solu- } \\
\text { tion }\end{array}$ & - & 11681451001 & $\begin{array}{l}\text { Roche Diagnostics GmbH, } \\
\text { Mannheim, } \\
\text { www.roche-applied- } \\
\text { science.com }\end{array}$ \\
\hline $\begin{array}{l}\text { Objektträger, Thermo } \\
\text { Scientific, Superfrost } \\
\text { Plus }\end{array}$ & - & J1800AMNZ & $\begin{array}{l}\text { Gerhard Menzel GmbH, } \\
\text { Braunschweig, } \\
\text { www.menzel.de }\end{array}$ \\
\hline $\begin{array}{l}\text { Paraffin, Surgipath, } \\
\text { Paraplast }\end{array}$ & - & $\mathrm{X} 880.1$ & $\begin{array}{l}\text { Carl Roth GmbH + Co. } \\
\text { KG, } \\
\text { Karlsruhe, } \\
\text { www.carlroth.com }\end{array}$ \\
\hline Parafilm & - & - & $\begin{array}{l}\text { Bemis flexible packaging, } \\
\text { Neenah (USA) } \\
\text { www.parafilm.de }\end{array}$ \\
\hline $\begin{array}{l}\text { PBS (Phosphate Buff- } \\
\text { ered Saline), } \\
500 \mathrm{ml}\end{array}$ & - & 14-190094 & $\begin{array}{l}\text { GIBCO } \\
\text { Invitrogen Corporation, } \\
\text { Karlsruhe } \\
\text { www.invitrogen.com }\end{array}$ \\
\hline $\begin{array}{l}\text { Penicillin / Streptomy- } \\
\text { cin, } \\
\mathbf{1 0 0} \mathrm{ml}\end{array}$ & $\begin{array}{l}10.000 \mathrm{U} / \mathrm{mL} \text { Peni- } \\
\text { cillin, } \\
10.000 \mu \mathrm{g} / \mathrm{mL} \\
\text { Streptomycin }\end{array}$ & $15140-122$ & $\begin{array}{l}\text { GIBCO } \\
\text { Invitrogen Corporation, } \\
\text { Karlsruhe } \\
\text { www.invitrogen.com }\end{array}$ \\
\hline Petrischalen & - & 83.1801 & $\begin{array}{l}\text { Sarstedt Group, } \\
\text { Newton (UK), } \\
\text { www.sarstedt.com }\end{array}$ \\
\hline Pikrinsäure & $>98 \%$ & $416226 / 1$ & $\begin{array}{l}\text { Fluka Chemie GmbH, } \\
\text { Steinheim }\end{array}$ \\
\hline Pipetten $1 \mathrm{ml}$ & - & 357522 & $\begin{array}{l}\text { BD Falcon, } \\
\text { Heidelberg, } \\
\text { www.bd.com }\end{array}$ \\
\hline Pipetten, $5 \mathrm{ml}$ & - & E 4860.0511 & $\begin{array}{l}\text { Starlab Deutschland } \\
\text { GmbH, } \\
\text { Hamburg, } \\
\text { www.starlab.de }\end{array}$ \\
\hline
\end{tabular}




\begin{tabular}{|c|c|c|c|}
\hline Pipetten, $10 \mathrm{ml}$ & - & E 4860.1011 & $\begin{array}{l}\text { Starlab Deutschland } \\
\text { GmbH, } \\
\text { Hamburg, } \\
\text { www.starlab.de }\end{array}$ \\
\hline Pipetten, 25 ml & - & E 4860.2511 & $\begin{array}{l}\text { Starlab Deutschland } \\
\text { GmbH, } \\
\text { Hamburg, } \\
\text { www.starlab.de }\end{array}$ \\
\hline Pipettenspitzen $10 \mu \mathrm{l}$ & - & S $1120-3810$ & $\begin{array}{l}\text { Starlab Deutschland } \\
\text { GmbH, } \\
\text { Hamburg, } \\
\text { www.starlab.de }\end{array}$ \\
\hline Pipettenspitzen $100 \mu \mathrm{l}$ & - & S 1120-1840 & $\begin{array}{l}\text { Starlab Deutschland } \\
\text { GmbH, } \\
\text { Hamburg, } \\
\text { www.starlab.de }\end{array}$ \\
\hline Pipettenspitzen $1000 \mu \mathrm{l}$ & - & S $1120-3830$ & $\begin{array}{l}\text { Starlab Deutschland } \\
\text { GmbH, } \\
\text { Hamburg, } \\
\text { www.starlab.de }\end{array}$ \\
\hline Pipettus & - & 9808650 & $\begin{array}{l}\text { Hirschmann Laborgeräte } \\
\text { GmbH } 6 \text { Co. KG, } \\
\text { Eberstadt, } \\
\text { www.hirschmann- } \\
\text { laborgeraete.de }\end{array}$ \\
\hline Roticlear & - & A538.5 & $\begin{array}{l}\text { Carl Roth GmbH + Co. } \\
\text { KG, } \\
\text { Karlsruhe, } \\
\text { www.carlroth.com }\end{array}$ \\
\hline Roti-Histokit II & - & T160.1 & $\begin{array}{l}\text { Carl Roth GmbH + Co. } \\
\text { KG, } \\
\text { Karlsruhe, } \\
\text { www.carlroth.com }\end{array}$ \\
\hline Roti-Histol & - & 6640.2 & $\begin{array}{l}\text { Carl Roth GmbH + Co. } \\
\text { KG, } \\
\text { Karlsruhe, } \\
\text { www.carlroth.com }\end{array}$ \\
\hline Skalpell & - & 02.001 .30 .022 & $\begin{array}{l}\text { Feather Safety Razor Co., } \\
\text { Osaka (Japan), } \\
\text { www.feather.co.jp }\end{array}$ \\
\hline $\begin{array}{l}\text { Stickstofftank, } \\
\text { MVE, Cryosystem } 4000\end{array}$ & - & - & $\begin{array}{l}\text { Chart BioMedical Divi- } \\
\text { sion, } \\
\text { Ohio (USA), } \\
\text { www.chartbiomed.com }\end{array}$ \\
\hline $\begin{array}{l}\text { TC-6-Well-Platten, } \\
\text { Cellstar }\end{array}$ & - & 657160 & $\begin{array}{l}\text { Greiner Bio-One, } \\
\text { Frickenhausen, } \\
\text { www.greinerbioone.com }\end{array}$ \\
\hline $\begin{array}{l}\text { Tiefkühllagergerät, } \\
\text { HFU } 586 \text { TOP, }-80{ }^{\circ} \mathrm{C}\end{array}$ & - & 50123495 & $\begin{array}{l}\text { Thermo Scientific Inc., } \\
\text { Waltham (USA), } \\
\text { www.thermoscientific.com }\end{array}$ \\
\hline $\begin{array}{l}\text { tri-Natriumcitrat- } \\
\text { Dihydrat }\end{array}$ & - & 106448 & $\begin{array}{l}\text { Carl Roth GmbH + Co. } \\
\text { KG, } \\
\text { Karlsruhe, } \\
\text { www.carlroth.com }\end{array}$ \\
\hline
\end{tabular}




\begin{tabular}{|c|c|c|c|}
\hline Tris $\mathrm{HCl}$ & - & AE15.2 & $\begin{array}{l}\text { Carl Roth GmbH + Co. } \\
\text { KG, } \\
\text { Karlsruhe, } \\
\text { www.carlroth.com }\end{array}$ \\
\hline Triton X 100 & - & 3051.3 & $\begin{array}{l}\text { Carl Roth GmbH + Co. } \\
\text { KG, } \\
\text { Karlsruhe, } \\
\text { www.carlroth.com }\end{array}$ \\
\hline $\begin{array}{l}\text { Trypsin-EDTA (1 X), } \\
\text { 100ml }\end{array}$ & $0,05 \%$ & $25300-054$ & $\begin{array}{l}\text { GIBCO } \\
\text { Invitrogen Corporation, } \\
\text { Karlsruhe, } \\
\text { www.invitrogen.com }\end{array}$ \\
\hline TUNEL-Kit & - & 11684809910 & $\begin{array}{l}\text { Roche Diagnostics GmbH, } \\
\text { Mannheim, } \\
\text { www.roche-applied- } \\
\text { science.com }\end{array}$ \\
\hline Wasserbad & - & - & $\begin{array}{l}\text { Memmert GmbH + Co. } \\
\text { KG, } \\
\text { Schwabach, } \\
\text { www.memmert.de }\end{array}$ \\
\hline Wasserbad & - & - & $\begin{array}{l}\text { Medax GmbH \& Co. KG, } \\
\text { Neumünster, } \\
\text { www.medax-kiel.de }\end{array}$ \\
\hline $\begin{array}{l}\text { Werkbank, HERA safe } \\
\text { HS } 18\end{array}$ & - & 51012775 & $\begin{array}{l}\text { Heraeus Holding } \mathrm{GmbH} \text {, } \\
\text { Hanau, } \\
\text { www.heraeus.de }\end{array}$ \\
\hline Xylol (Isomere) & - & 9713.3 & $\begin{array}{l}\text { Carl Roth GmbH + Co. } \\
\text { KG, } \\
\text { Karlsruhe, } \\
\text { www.carlroth.com }\end{array}$ \\
\hline $\begin{array}{l}\text { Zellkulturflasche } 175 \\
\text { cm }^{2}\end{array}$ & - & 660175 & $\begin{array}{l}\text { Greiner Bio-One, } \\
\text { Frickenhausen, } \\
\text { www.greinerbioone.com }\end{array}$ \\
\hline Zellkulturflasche $25 \mathrm{~cm}^{2}$ & - & 690175 & $\begin{array}{l}\text { Greiner Bio-One, } \\
\text { Frickenhausen, } \\
\text { www.greinerbioone.com }\end{array}$ \\
\hline Zellkulturflasche $75 \mathrm{~cm}^{2}$ & - & 658175 & $\begin{array}{l}\text { Greiner Bio-One, } \\
\text { Frickenhausen, } \\
\text { www.greinerbioone.com }\end{array}$ \\
\hline $\begin{array}{l}\text { Zellzählgerät, Nexcelom } \\
\text { Cellometer Auto T4 }\end{array}$ & - & - & $\begin{array}{l}\text { Nexcolom Bioscience } \\
\text { LLC, } \\
\text { Lawrence (USA), } \\
\text { www.nexcelom.com }\end{array}$ \\
\hline $\begin{array}{l}\text { Zentrifuge, Laboratory } \\
\text { Centrifuges 2K15C }\end{array}$ & - & - & $\begin{array}{l}\text { Sigma Laborzentrifugen } \\
\text { GmbH, } \\
\text { Osterode am Harz; } \\
\text { www.sigma-zentrifugen.de }\end{array}$ \\
\hline
\end{tabular}




\section{Literaturverzeichnis}

Allen E, Irwin C, Ziada H, Mullally B, Byrne PJ. (2007): Periodontics: 6. The management of gingival recession. Dent Update $\underline{34}, 534-536,538-540$

Bach AD, Stem-Straeter J, Beier JP, Bannasch H, Stark GB (2003): Engineering of muscle tissue. Clin Plast Surg. $\underline{30}$, 589-599

Barbani N, Giusti P, Lazzeri L, Polacco G, Pizzirani G (1995): Bioartificial materials based on collagen: 1. Collagen cross-linking with gaseous glutaraldehyde. J Biomat Sci Polym Ed ㅁ, 461-469

Battiston B, Raimondo S, Tos P, Gaidano V, Audisio C, Scevola A, Perroteau I (2009): Chapter 11: Tissue engineering of peripheral nerves. Int Rev Neurobiol 87, 227-249

Bell E, Sher S, Hull B, Merrill C, Rosen S, Chamson A, Asselineau D, Dubertret L, Coulomb B, Lapiere C (1983): The reconstitution of living skin. J Invest Dermatol $\underline{81}, 2-10$

Bessa PC, Casal M, Reis RL (2008): Bone morphogenetic proteins in tissue engineering: the road from laboratory to clinic, part II (BMP delivery). J Tissue Eng Regen Med 2, 81-96

Bissell MJ, Rizki A, Mian IS (2003): Tissue architecture: the ultimate regulator of breast epithelial function. Curr Opin Cell Biol 15, 753-762

Browder IW, Litwin MS (1986): Use of absorbable collagen for hemostasis in general surgical patients. Am Surg 52,492-494

Bruzewicz DA, McGuigan AP, Whitesides GM (2008): Fabrication of a modular tissue construct in a microfluidic chip. Lab on a chip $\underline{8}, 663-671$

Byrne EM, Farrell E, McMahon LA, Haugh MG, O'Brien FJ, Campbell VA, Prendergast PJ, O'Connell BC (2008): Gene expression by marrow stromal cells in a porous collagen-glycosaminoglycan scaffold is affected by pore size and mechanical stimulation. J Mater Sci Mater Med 19, 3455-3463

Cairo F, Cortellini P, Tonetti M, Nieri M, Mervelt J, Cincinelli S, Pini-Prato G (2012): Coronally advanced flap with and without connective tissue graft for the treatment of single maxillary gingival recession with loss of inter-dental attachment. A randomized controlled clinical trial. J Clin Periodontol 39, 760-768

Caliari SR, Ramirez MA, Harley BAC (2011): The development of collagen-GAG scaffold-membrane composites for tendon tissue engineering. Biomaterials $\underline{32}, 8990$ 8998

Caplan AI (2007): Adult mesenchymal stem cells for tissue engineering versus regenerative medicine. J Cell Physiol 213, 341-347

Carletti E, Motta A, Migliaresi C (2011): Scaffolds for tissue engineering and 3D cell culture. Methods Mol Biol 695, 17-39 
Castañeda F, Kinne RKH (2000): Short exposure to millimolar concentrations of ethanol induces apoptotic cell death in multicellular HepG2 spheroids. J Cancer Res Clin Oncol $\underline{126}, 305-310$

Chen M, Przyborowski M, Berthiaume F (2009): Stem cells for skin tissue engineering and wound healing. Crit Rev Biomed Eng $\underline{\text { 37, 399-421 }}$

\section{Dashtdar H, Murali MR, Abbas AA, Suhaeb AM, Selvaratnam L, Tay LX, Kamarul T} (2013): PVA-chitosan composite hydrogel versus alginate beads as a potential mesenchymal stem cell carrier for the treatment of focal cartilage defects. Knee Surg Sports Traumatol Arthrosc, im Druck

Dayan D, Hiss Y, Hirshberg A, Bubis JJ, Wolman M (1989): Are the polarization colors of picrosirius red-stained collagen determined only by the diameter of the fibers?

Histochemistry $\underline{93}, 27-29$

De Miguel MP, Fuentes-Julián S, Blázquez-Martínez A, Pascual CY, Aller MA, Arias J, Arnalich-Montiel F (2012): Immunosuppressive properties of mesenchymal stem cells: advances and applications. Curr Mol Med 12, 574-591

Dhillon M, Mohan MS, Raju SM, Krishnamoorthy B, Lakhanpal M (2013): Ackerman's tumour of buccal mucosa in a leprosy patient. Lepr Rev $\underline{84}, 151-157$

Dominiak M, Saczko J, Gerber H, Rybak Z, Gredes T (2010): Use of primary culture of human fibroblasts in gingiva augmentation procedure. Biomed Tech (Berl) $\underline{55}$, 331-334

Dominiak M, Lysiak-Drwal K, Saczko J, Kunert-Keil C, Gedrange T (2012): The clinical efficacy of primary culture of human fibroblasts in gingival augmentation procedures-a preliminary report. Ann Anat $\underline{194}, 502-507$

Eckermann CW, Lehle K, Schmid SA, Wheatley DN, Kunz-Schughart LA (2011): Characterization and modulation of fibroblast/endothelial cell co-cultures for the in vitro preformation of three-dimensional tubular networks. Cell Biol Int $\underline{35}, 1097-1110$

Geesin JC, Brown LJ, Liu Z, Berg RA (1996): Development of a skin model based on insoluble fibrillar collagen. J Biomed Mat Res $\underline{33}, 1-8$

Geesin JC, Gordon J, Berg R (1993): Regulation of collagen synthesis in human dermal fibroblasts by the sodium and magnesium salts of ascorbyl-2-phosphate. Skin Pharmacol $\underline{6}, 65-71$

Gelain F, Bottai D, Vescovi A, Zhang S (2006): Designer self-assembling peptide nanofiber scaffolds for adult mouse neural stem cell 3-dimensional cultures. PLoS One $\underline{1}, 119$.

Gellrich NC, Schramm A, Hara I, Gutwald R, Düker J, Schmelzeisen R (2001): Versatility and donor site morbidity of the lateral upper arm flap in intraoral reconstruction. Otolaryngol Head Neck Surg 124, 549-555

Ghezzi CE, Muja N, Marelli B, Nazhat SN (2011): Real time responses of fibroblasts to plastically compressed fibrillar collagen hydrogels. Biomaterials $\underline{32}, 4761-4772$ 
Ghosh MM, Boyce S, Layton C, Freedlander E, Mac Neil S (1997): A comparison of methodologies for the preparation of human epidermal-dermal composites. Ann Plast Surg 39, 390-404

Gong Y, He L, Li J, Zhou Q, Ma Z, Gao C, Shen J. (2007) Hydrogel-filled polylactide porous scaffolds for cartilage tissue engineering. J Biomed Mater Res B Appl Biomater $\underline{82}, 192-204$

Gorham SD, Light ND, Diamond AM, Willins MJ, Bailey AJ, Wess TJ, Leslie NJ (1992): Effect of chemical modifications on the susceptibility of collagen to proteolysis. II. Dehydrothermal crosslinking. Int J Biol Macromol 14, 129-138

Griffith CK, Miller C, Sainson RCA, Calvert JW, Jeon NL, Hughes CCW, George SC (2005): Diffusion limits of an in vitro thick prevascularized tissue. Tissue Eng 11, 257266

Harkness RD (1966): Collagen. Sci Prog 또, 257-274

Harrison CA, Heaton MJ, Layton CM, Mac Neil S (2006): Use of an in vitro model of tissue-engineered human skin to study keratinocyte attachment and migration in the process of reepithelialization. Wound Repair Regen 14, 203-209

Haycock JW (2011): 3D cell culture: a review of current approaches and techniques. Methods Mol Biol $\underline{695}, 1-15$

Holopainen IE (2005): Organotypic hippocampal slice cultures: a model system to study basic cellular and molecular mechanisms of neuronal cell death, neuroprotection, and synaptic plasticity. Neurochem Res $\underline{30}, 1521-1528$

Holt GR (1990): Concepts of soft-tissue trauma repair. Otolaryngol Clini North Am $\underline{23}$, $1019-1030$

Hunt NC, Smith AM, Gbureck U, Shelton RM, Grover LM (2010): Encapsulation of fibroblasts causes accelerated alginate hydrogel degradation. Acta Biomater $\underline{6}, 3649$ 3656

Hurvitz KA, Kobayashi M, Evans GRD (2006): Current options in head and neck reconstruction. Plast Reconstr Surg 118, 122-133

Jahnke PV, Sandifer JB, Gher ME, Gray JL, Richardson AC (1993): Thick free gingival and connective tissue autografts for root coverage. J Periodontol 64, 315-322

Jhaveri HM, Chavan MS, Tomar GB, Deshmukh VL, Wani MR, Miller PD (2010): Acellular dermal matrix seeded with autologous gingival fibroblasts for the treatment of gingival recession: a proof-of-concept study. J Periodontol $\underline{81}$, 616-625

Ji W, Zhang Y, Hu S, Zhang Y (2013): Biocompatibility study of a silk fibroin-chitosan scaffold with adipose tissue-derived stem cells in vitro. Exp Ther Med $\underline{6}, 513-518$ 
Junqueira LC, Bignolas G, Brentani RR (1979): Picrosirius staining plus polarization microscopy, a specific method for collagen detection in tissue sections. Histochem $\mathrm{J} \underline{11}$, $447-455$

Justice BA, Badr NA, Felder RA (2009): 3D cell culture opens new dimensions in cellbased assays. Drug Discov Today $\underline{14}, 102-107$

Kassab MM, Cohen RE (2003): The etiology and prevalence of gingival recession. J Am Dent Assoc 134, 220-225

Kasten P, Beyen I, Niemeyer P, Luginbühl R, Bohner M, Richter W (2008): Porosity and pore size of beta-tricalcium phosphate scaffold can influence protein production and osteogenic differentiation of human mesenchymal stem cells: an in vitro and in vivo study. Acta Biomater $\underline{4}, 1904-1915$

Kelm JM, Timmins NE, Brown CJ, Fussenegger M, Nielsen LK (2003): Method for generation of homogeneous multicellular tumor spheroids applicable to a wide variety of cell types. Biotechnol Bioeng $\underline{83}, 173-180$

Khan R, Khan MH (2013): Use of collagen as a biomaterial: An update. J Indian Soc Periodontol 17, 539-542

Kim SS, Utsunomiya H, Koski JA, Wu BM, Cima MJ, Sohn J, Mukai K, Griffith LG, Vacanti JP (1998): Survival and function of hepatocytes on a novel three-dimensional synthetic biodegradable polymer scaffold with an intrinsic network of channels. Ann Surg $\underline{228}, 8-13$

Kinikoglu B, Auxenfans C, Pierrillas P, Justin V, Breton P, Burillon C, Hasirci V, Damour $O$ (2009): Reconstruction of a full-thickness collagen-based human oral mucosal equivalent. Biomaterials $\underline{30}, 6418-6425$

Koide M, Osaki K, Konishi J, Oyamada K, Katakura T, Takahashi A, Yoshizato K (1993): A new type of biomaterial for artificial skin: dehydrothermally cross-linked composites of fibrillar and denatured collagens. J Biomed Mat Res $\underline{27}$, 79-87

Köseoğlu S, Duran İ, Sağlam M, Bozkurt SB, Kırtıloğlu OS, Hakkı S (2013): Efficacy of collagen membrane seeded with autologous gingival fibroblasts in gingival recession treatment: a randomized, controlled pilot study. J Periodontol $\underline{84}$, 1416-1424

Kumar NG, Thapliyal GK (2012): Free dermal fat graft for restoration of soft tissue defects in maxillofacial surgery. J Maxillofac Oral Surg 11, 319-322

Kunz-Schughart LA, Schroeder JA, Wondrak M, van Rey F, Lehle K, Hofstaedter F, Wheatley DN (2006): Potential of fibroblasts to regulate the formation of threedimensional vessel-like structures from endothelial cells in vitro. Am J Physiol Cell Physiol 290, 1385-1398

L'Heureux N, Dusserre N, Konig G, Victor B, Keire P, Wight TN, Chronos NAF, Kyles AE, Gregory CR, Hoyt G (2006): Human tissue-engineered blood vessels for adult arterial revascularization. Nat Med $\underline{12}, 361-365$ 
Langer R, Vacanti JP (1993): Tissue Engineering. Science 260, 920-926.

Lee H, Yeo M, Ahn SH, Kang DO, Jang CH, Lee H, Park GM, Kim GH (2011):

Designed hybrid scaffolds consisting of polycaprolactone microstrands and electrospun collagen-nanofibers for bone tissue regeneration. J Biomed Mater Res B Appl Biomater 97, 263-270

Lee M, Wu BM, Dunn JCY (2008): Effect of scaffold architecture and pore size on smooth muscle cell growth. J Biomed Mater Res A $\underline{87}, 1010-1016$

Lee MY, Tsai WW, Chen HJ, Chen JP, Chen CH, Yeh WL, An J (2013): Laser sintered porous polycaprolacone scaffolds loaded with hyaluronic acid and gelatin-grafted thermoresponsive hydrogel for cartilage tissue engineering. Biomed Mater Eng $\underline{23}$, $533-543$

Levine DW, Wong JS, Wang DI, Thilly WG (1977): Microcarrier cell culture: new methods for research-scale application. Somatic Cell Genet $\underline{3}, 149-155$

Liu R, Chen X, Gellman SH, Masters KS (2013): Nylon-3 Polymers That Enable Selective Culture of Endothelial Cells. J Am Chem Soc, im Druck

Llames S, Recuero I, Romance A, García E, Peña I, Del Valle AF, Meana A, Larcher F, Del Río M (2013): Tissue-Engineered Oral Mucosa for Mucosal Reconstruction in a Pediatric Patient With Hemifacial Microsomia and Ankyloglossia. Cleft Palate Craniofac J, im Druck

Lotfi G, Shokrgozar MA, Mofid R, Abbas FM, Ghanavati F, Bagheban AA, Shariati RP (2011): A clinical and histologic evaluation of gingival fibroblasts seeding on a chitosan-based scaffold and its effect on the width of keratinized gingiva in dogs. $\mathbf{J}$ Periodontol $\underline{82}, 1367-1375$

Lu SJ, Kelley T, Feng Q, Chen A, Reuveny S, Lanza R, Oh SKW (2013): 3D microcarrier system for efficient differentiation of human pluripotent stem cells into hematopoietic cells without feeders and serum [corrected]. Regen Med $\underline{8}$, 413-424

Lüllmann-Rauch, R: Histologie. 2. Auflage; Georg Thieme Verlag KG, Stuttgart 2007

MacNeil S, Shepherd J, Smith L (2011): Production of tissue-engineered skin and oral mucosa for clinical and experimental use. Methods Mol Biol 695, 129-153

Marini MG, Greghi SLA, Passanezi E, Sant'ana ACP (2004): Gingival recession: prevalence, extension and severity in adults. J Appl Oral Sci 12, 250-255

McGuigan AP, Sefton MV (2006): Vascularized organoid engineered by modular assembly enables blood perfusion. Proc Natl Acad Sci U S A $\underline{103}$, 11461-11466

McGuigan AP, Sefton MV (2007): Design and Fabrication of Sub-mm-Sized Modules Containing Encapsulated Cells for Modular Tissue Engineering. Tissue Eng 13, 10691078 
McGuire MK, Nunn ME (2005): periodontal applications of a living tissue-engineered human fibroblast-derived dermal substitute. I. Comparison to the gingival autograft: a randomized controlled pilot. J Periodontol $\underline{76}, 867-880$

\section{Moharamzadeh K, Brook IM, Van Noort R, Scutt AM, Smith KG, Thornhill MH} (2008): Development, optimization and characterization of a full-thickness tissue engineered human oral mucosal model for biological assessment of dental biomaterials. J Mater Sci Mater Med 19, 1793-1801

Mörmann W, Schaer F, Firestone AR (1980): The Relationship Between Success of Free Grafts and Transplant Thickness Gingival Shrinkage -A One Year Clinical Study. J Periodontol $\underline{52}, 74-80$

Müller HP, Eger T, Schorb A (1998): Gingival dimensions after root coverage with free connective tissue grafts. J Clin Periodontol 25, 424-430

Murata M, Huang BZ, Shibata T, Imai S, Nagai N, Arisue, M (1999): Bone augmentation by recombinant human BMP-2 and collagen on adult rat parietal bone. Int J Oral Maxillofac Surg 료, 232-237

Neff LP, Tillman BW, Yazdani SK, Machingal MA, Yoo JJ, Soker S, Bernish BW, Geary RL, Christ GJ (2011): Vascular smooth muscle enhances functionality of tissue-engineered blood vessels in vivo. J Vasc Surg 53, 426-434

Neunzehn J, Lüttenberg B, Wiesmann HP (2012): Investigation of biomaterials by human epithelial gingiva cells: an in vitro study. Head Face Med $\underline{8}, 1-11$

Novotny L, Crha M, Rauser P, Hep A, Misik J, Necas A, Vondrys D (2012): Novel biodegradable polydioxanone stents in a rabbit airway model. J Thorac Cardiovasc Surg $\underline{143}, 437-444$

O'Brien LE, Jou TS, Pollack AL, Zhang Q, Hansen SH, Yurchenco P, Mostov KE (2001): Rac1 orientates epithelial apical polarity through effects on basolateral laminin assembly. Nat Cell Biol $\underline{3}, 831-838$

Pampaloni F, Reynaud EG, Stelzer EHK (2008): The third dimension bridges the gap between cell culture and live tissue. Nat Rev Mol Cell Biol $\underline{8}, 839-845$

Panduranga Rao K (1995): Recent developments of collagen-based materials for medical applications and drug delivery systems. J Biomat Sci Polym Ed 7, 623-645

Phillips JB, Brown R (2011): Micro-structured materials and mechanical cues in 3D collagen gels. Methods Mol Biol 695,183-196

Pilloni A, Dominici F, Rossi R (2013): Laterally moved, coronally advanced flap for the treatment of a single Stillman's cleft. A 5-year follow-up. Eur J Esthet Dent $\underline{8}$, 390-396.

Pinnell SR (1985): Regulation of collagen biosynthesis by ascorbic acid: a review. Yale J Biol Med 58,553-559

Poland DE, Kaufman HE (1988): Clinical uses of collagen shields. J Cataract Refrac Surg $\underline{14}, 489-491$ 
Prestwich GD (2008): Engineering a clinically-useful matrix for cell therapy. Organogenesis $\underline{4}, 42-47$

Preynat-Seauve O, de Rham C, Tirefort D, Ferrari-Lacraz S, Krause KH, Villard J (2009): Neural progenitors derived from human embryonic stem cells are targeted by allogeneic T and natural killer cells. J Cell Mol Med $\underline{13}$, 3556-3569

Quint C, Arief M, Muto A, Dardik A, Niklason LE (2012): Allogeneic human tissueengineered blood vessel. J Vasc Surg $\underline{55}$, 790-798

Raimondo S, Fornaro M, Tos P, Battiston B, Giacobini-Robecchi MG, Geuna S (2011): Perspectives in regeneration and tissue engineering of peripheral nerves. Ann Anat $\underline{193}$, 334-340

Ramachandran GN, Sasisekharan V (1965): Refinement of the structure of collagen. Biochim Biophys Acta 109, 314-316

Rebele SF, Zuhr O, Schneider D, Jung RE, Hürzeler MB (2014): Tunnel technique with connective tissue graft versus coronally advanced flap with enamel matrix derivative for root coverage: a RCT using 3D digital measuring methods. Part II. Volumetric studies on healing dynamics and gingival dimensions. J Clin Periodontol 41, 593-603

Rich L, Whittaker P (2005): Collagen and Picrosirius Red Staining: A polarized light assesment of fibrillar hue and spatial distribution. Braz J Morphol Sci 22, 97-104

Rieck KL, W. Fillmore WJ, Ettinger KS (2013): Late revision or correction of facial trauma-related soft-tissue deformities. Oral Maxillofac Surg Clin North Am $\underline{25}, 697-713$

Riedel F, Hörmann K (2005): Plastic surgery of skin defects in the face. Principles and perspectives. HNO $\underline{53}, 1020-1036$

Rimondini L, Mele S (2009): Stem cell technologies for tissue regeneration in dentistry. Minerva Stomatol $\underline{58}, 483-500$

Ringe J, Kaps C, Burmester GR, Sittinger M (2002): Stem cells for regenerative medicine: advances in the engineering of tissues and organs. Naturwissenschaften $\underline{89}, 338-351$

Rössler B, Kreuter J, Scherer D (1995): Collagen microparticles: preparation and properties. J Microencapsul $\underline{12}, 49-57$

Rubin AL, Stenzel KH, Miyata T, White MJ, Dunn M (1973): Collagen as a vehicle for drug delivery. Preliminary report. J Clin Pharmacol 13, 309-312

Sabolinski ML, Alvarez O, Auletta M, Mulder G, Parenteau NL (1996): Cultured skin as a 'smart material' for healing wounds: experience in venous ulcers. Biomaterials $\underline{17}$, $311-320$

Schwarz RP, Goodwin TJ, Wolf DA (1992): Cell culture for three-dimensional modeling in rotating-wall vessels: an application of simulated microgravity. J Tissue Cult Methods $\underline{14}, 51-57$ 
Seo YK, Song KY, Kim YJ, Park JK (2007): Wound healing effect of acellular artificial dermis containing extracellular matrix secreted by human skin fibroblasts. Artif Organs $\underline{31}, 509-520$

Sgonc R, Boeck G, Dietrich H, Gruber J, Recheis H, Wick G (1994): Simultaneous determination of cell surface antigens and apoptosis. Trends Genet $\underline{10}, 41-42$

Shao HJ, Chen CS, Lee IC, Wang JH, Young TH (2009): Designing a three-dimensional expanded polytetrafluoroethylene-poly(lactic-co-glycolic acid) scaffold for tissue engineering. Artif Organs 33, 309-317

Shen Z, Guo S, Ye D, Chen J, Kang C, Qiu S, Lu D, Li Q, Xu K, Lv J (2013): Skeletal muscle regeneration on protein-grafted and microchannel-patterned scaffold for hypopharyngeal tissue engineering. Biomed Res Int, im Druck

Shuker ST (2010): Facial skin-mucosal biodynamic blast injuries and management. J Oral Maxillofac Surg $\underline{68}, 1818-1825$

Silva CO, Del Peloso Ribeiro E, Sallum AW, Tatakis DN (2010): Free gingival grafts: graft shrinkage and donor-site healing in smokers and non-smokers. J Periodontol $\underline{81}$, 692-701

Swijnenburg RJ, Schrepfer S, Cao F, Pearl JI, Xie X, Connolly AJ, Robbins RC, Wu JC (2008): In vivo imaging of embryonic stem cells reveals patterns of survival and immune rejection following transplantation. Stem Cells Dev 17, 1023-1029

Tao S, Young C, Redenti S, Zhang Y, Klassen H, Desai T, Young MJ (2007): Survival, migration and differentiation of retinal progenitor cells transplanted on micro-machined poly(methyl methacrylate) scaffolds to the subretinal space. Lab Chip $\underline{7}, 695-701$

Thesleff I, Tummers M (2003): Stem cells and tissue engineering: prospects for regenerating tissues in dental practice. Med Princ Pract 12, 43-50

Thoma DS, Hämmerle CHF, Cochran DL, Jones AA, Görlach C, Uebersax L, Mathes S, Graf-Hausner U, Jung RE (2011): Soft tissue volume augmentation by the use of collagen-based matrices in the dog mandible -- a histological analysis. J Clin Periodontol $\underline{38}, 1063-1070$

Thoma DS, Sancho-Puchades M, Ettlin DA, Hämmerle CHF, Jung RE (2012): Impact of a collagen matrix on early healing, aesthetics and patient morbidity in oral mucosal wounds - a randomized study in humans. J Clin Periodontol $\underline{39}$, 157-165

Thomson JA, Itskovitz-EIdor J, Shapiro SS, Waknitz MA, Swiergiel JJ, Marshall VS, Jones JM (1998): Embryonic stem cell lines derived from human blastocysts. Science $\underline{282}, 1145-1147$

Thorwarth M, Eulzer C, Bader R, Wolf C, Schmidt M, Schultze-Mosgau S (2008): Free flap transfer in cranio-maxillofacial surgery: a review of the current data. Oral Maxillofac Surg $\underline{12}$, 113-124 
Timmins NE, Harding FJ, Smart C, Brown MA, Nielsen LK (2005): Method for the generation and cultivation of functional three-dimensional mammary constructs without exogenous extracellular matrix. Cell Tissue Res $\underline{320}$, 207-210

Trau H, Dayan D, Hirschberg A, Hiss Y, Bubis JJ, Wolman M (1991): Connective tissue nevi collagens. Study with picrosirius red and polarizing microscopy. Am J Dermatopathol 13, 374-377

Tsutsumi K, Fujikawa H, Kajikawa T, Takedachi M, Yamamoto T, Murakami S (2012): Effects of L-ascorbic acid 2-phosphate magnesium salt on the properties of human gingival fibroblasts. J Periodontal Res $\underline{47}, 263-271$

Tziampazis E, Sambanis A (1995): Tissue engineering of a bioartificial pancreas: modeling the cell environment and device function. Biotechnol Prog 11, 115-126

Van Wezel AL (1967): Growth of cell-strains and primary cells on micro-carriers in homogeneous culture. Nature 216, 64-65

Varani J, Dame M, Beals TF, Wass JA (1983): Growth of three established cell lines on glass microcarriers. Biotechnol Bioeng $\underline{25}, 1359-1372$

Weadock KS, Miller EJ, Keuffel EL, Dunn MG (1996): Effect of physical crosslinking methods on collagen-fiber durability in proteolytic solutions. J Biomed Mater Res $\underline{32}$, $221-226$

Wedge CI, Rootman DS (1992): Collagen shields: efficacy, safety and comfort in the treatment of human traumatic corneal abrasion and effect on vision in healthy eyes. Can J Ophthalmol 27, 295-298

Wei FC, Celik N, Yang WG, Chen ICH, Chang YM, Chen HC (2003): Complications after reconstruction by plate and soft-tissue free flap in composite mandibular defects and secondary salvage reconstruction with osteocutaneous flap. Plast Reconstr Surg $\underline{112}, 37-42$

Welsch, U: Lehrbuch Histologie. 2. Ausgabe; Elsevier Urban \& Fischer, München 2006

Wu TT, Ko EWC, Chen PKT, Huang CS (2013): Craniofacial characteristics in unilateral complete cleft lip and palate patients with congenitally missing teeth. Am J Orthod Dentofacial Orthop 144, 381-390

Yi T, Song SU (2012): Immunomodulatory properties of mesenchymal stem cells and their therapeutic applications. Arch Pharm Res $\underline{35}$, 213-221

Zou J, Yuan C, Wu C, Cao C, Shi Q, Yang H (2013): Isolation and osteogenic differentiation of skeletal muscle-derived stem cells for bone tissue engineering. Mol Med Rep 1, 185-191

Zuhr O, Bäumer D, Hürzeler M (2014): The addition of soft tissue replacement grafts in plastic periodontal and implant surgery: critical elements in design and execution. J Clin Periodontol $\underline{41}, 123-142$. 